МИНИСТЕРСТВО ОБРАЗОВАНИЯ И НАУКИ РОССИИ

Федеральное государственное бюджетное образовательное учреждение высшего профессионального образования «Башкирский государственный педагогический университет им. М. Акмуллы»

\author{
Л. М. Билалова, О. М. Иванова, Л. Ф. Фатихова
}

\title{
РУССКИЙ ЯЗЫК И МАТЕМАТИКА В НАЧАЛЬНОЙ ШКОЛЕ В ОПОРНЫХ ТАБЛИЦАХ
}

Методическое пособие

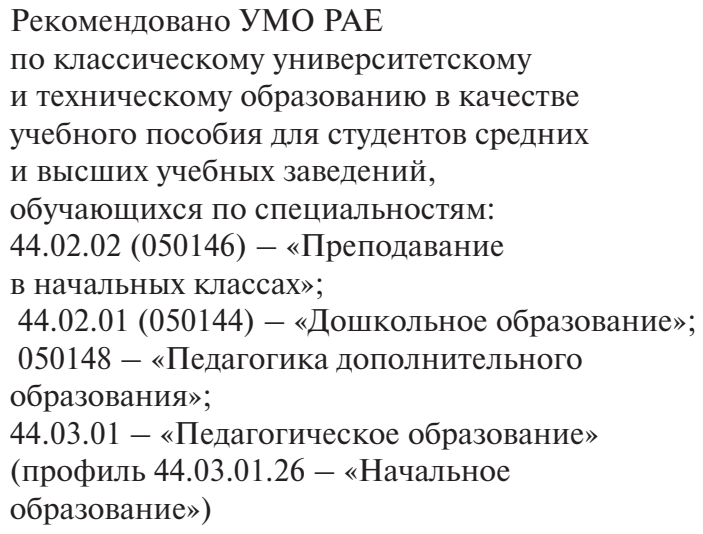


УДК 373.3

ББК 74.26

Б61

\section{Рещензенты:}

Тутолмин Александр Викторович - Grand Ph. D, доктор педагогических наук, доцент, профессор кафедры дошкольного и начального образования ФГБОУ ВО «ГГПИ им. В.Г. Короленко»;

Кохичко Андрей Николаевич - доктор педагогических наук, доцент, профессор кафедры педагогики, ФГБОУ ВО «Мурманский арктический государственный университет».

\section{Билалова Л. М., Иванова О. М., Фатихова Л. Ф.}

Б61 Русский язык и математика в начальной школе в опорных таблицах: методическое пособие [Текст] / Л. М. Билалова, О. М. Иванова, Л. Ф. Фатихова. - М.: Издательский дом Академии Естествознания, 2018. - 104 c.

\section{ISBN 978-5-91327-529-5 \\ DOI 10.17513/np.312}

В пособии содержится материал, который может быть использован на уроках русского языка и математики в начальных классах. В пособии представлены опорные таблицы, применение которых создаст условия для развития познавательной деятельности обучающихся в процессе формирования понятий о языковых явлениях и математических закономерностях; позволит обучающимся успешно и сознательно усвоить программный материал по русскому языку и математике. Представленный в пособии учебный материал согласован с программой обучения «Начальная школа XXI века».

Пособие предназначено для учителей начальной школы. Материалы пособия могут использоваться студентами отделений начального образования педагогических вузов, а также в системе повышения квалификации работников образования.

Работа выполнена на кафедре специальной педагогики и психологии ФГБОУ ВПО «БГПУ им. М. Акмулль».

ISBN 978-5-91327-529-5

(с) Билалова Л.М., Иванова О.М., Фатихова Л.Ф., 2018

(c) ГОУ ВО «Башкирский государственный университет им. М. Акмуллы», 2018

(с) ИД «Академия Естествознания»

(c) $\mathrm{AHO}$ «Академия Естествознания» 


\section{ПРЕДИСДОВИЕ}

Данное методическое пособие появилось в результате освоения школьниками программы обучения «Начальная школа XXI века». Имея долголетний педагогический опыт работы с детьми дошкольного и начального школьного возраста, мы не сразу сумели найти формы и методы донесения до обучающихся способов решения заданий, предлагаемых в учебниках по указанной программе.

Те схемы, таблицы, текстовые пояснения, которые представлены в данном пособии, родились в ходе непосредственного общения с нашими детьми, их одноклассниками, сверстниками и родителями.

Думается, что наш опыт, представленный в данном пособии, окажется полезным широкому кругу читателей, включая педагогов, родителей и, конечно, детей, осваивающих программу «Начальная школа XXI века». 


\section{ВВЕДЕНИЕ}

Опорные таблицы являются надежным инструментом организации обучающихся для процесса усвоения знаний, их систематизации, формирования умения использовать их при выполнении учебных заданий. Опорные таблицы решают не только узкие задачи формирования какого-либо предметного умения, но и способствуют достижению более широких целей - позволяют обучить детей умению обобщать, классифицировать и сравнивать явления, находить закономерности, т. е. способствуют формированию у обучающихся общих приёмов познавательной деятельности (общеинтеллектуальных умений), применение которых необходимо не только на уроках русского языка и математики, но и при изучении других школьных дисциплин, а также явлений окружающей действительности в целом. К таким общеинтеллектуальным умениям П. Я. Гальпериным и Т. Ф. Талызиной, отнесены ориентировка в задании, планирование и самоконтроль [1; 9], а Е. Н. Кабановой-Меллер [2], 3. И. Калмыковой [3], Н. А. Менчинской [4], А. И. Раевым [6] и др.) - мыслительные умения (умение сравнивать, обобщать, классифицировать и др.).

Опорные таблицы позволяют организовать дедуктивный способ познания в процессе освоения нового. В противовес индуктивному способу, который провоцирует действие методом «проб и ошибок» (от частного к общему), дедуктивный способ позволяет раскрыть общее основание в явлениях и приложить усвоенный способ действия для решения внешне различных, но по внутреннему содержанию единых интеллектуальных, в том числе и учебных, задач.

Работа с опорными таблицами основана на принципах обучения обучающихся младшего школьного возраста.

Принцип деятельностного подхода сформулирован на основе теории деятельности А. Н. Леонтьева и ориентирует на то, что работу по формированию учебно-познавательных умений целесообразно проводить с учетом процесса и структуры деятельности [5]. Учитывая, что мотивационный, операциональный и контрольно-оценочный компоненты неразрывно связаны в едином процессе деятельности, следует подходить к формированию умений в соответствии с той поэтапностью, которая соответствует в пространстве и времени ее актуализации ребенком. По мере овладения тем или иным умением педагог производит укрупнение единиц деятельности, т. е. усвоенные ранее умения включаются в более сложные виды деятельности (например, умение определять форму, время и другие характеристики глагола используется при морфологическом разборе глагола как части речи). 
Принцип поэтапного формирования умственных действий (П. Я. Гальперин, Н. Ф. Талызина) основан на теории, согласно которой формирование умственных действий у детей проходит ряд этапов, среди которых начальным и важнейшим этапом является формирование ориентировочной основы действия [1; 9]. Опорные таблицы способствуют формированию такой основы и способности применять ее при решении новых задач, позволяют организовать дедуктивный способ познания обучающихся.

Принцип единства сознания и деятельности состоит в том, что необходимое условие успешности обучения школьников - это сознательное усвоение учебного материала, способствующее последующему использованию усвоенных знаний и умений. Учитель посредством опорных таблиц получает возможность контролировать процесс усвоения детьми учебного материала и в случае необходимости оказывает помощь тем ребятам, которые испытывают затруднения в его понимании.

Принцип генерализации умственного действия предполагает перенос усвоенного способа действия в новые условия сформированного умения. Опорная таблица, на которой схематично в краткой форме дана последовательность выполнения интеллектуальной задачи, способствует отрыву действия от конкретного содержания, возможности применения его в других ситуациях.

Принцип наглядности в обучении обеспечивает привлечение наглядных средств в процесс усвоения обучающимися знаний и формирования у них различных умений и навыков. В младшем школьном возрасте в процессе познания обучающихся еще в значительной степени участвует нагляднообразное мышление, но в то же время осуществляется переход к абстрактному как ведущему виду мышления человека. Опорные таблицы, которые относятся к разряду абстрактной наглядности, способствуют этому переходу и обеспечивают осознанность процесса усвоения учебного материала.

Методика работы с опорными таблицами соотнесена с программой обучения «Начальная школа XXI века» и может быть включена в процесс обучения младших школьников дисциплинам «Русский язык» и «Математика» [7; 8]. В связи с этим материал пособия разбит на две главы. В первой главе «Таблицы на уроках русского языка» представлены опорные таблицы, которые могут быть использованы учителем на уроках русского языка. Во второй главе «Таблицы на уроках математики» представлены таблицы и формы работы с ними на уроках математики.

Опорные таблицы могут быть использованы учителем как на этапе объяснения новой темы, орфограммы, правила и др., так и в процессе закрепления и обобщения изученного. Таблицы могут использоваться обучающимися при затруднениях с выполнением упражнений и решением задач, как на уроке, так и в домашних заданиях. 
Таблицы распределены по группам в зависимости от изучаемого раздела программы и не предполагают строгой последовательности в их использовании. Так, в первой главе таблицы распределены для изучения разделов программы по русскому языку «Фонетика», «Части речи», «Состав слова», «Орфограммы», «Предложение». Во второй главе представлены таблицы, предназначенные для изучения нумерации и выполнения арифметических действий, изучения мер длины и усвоения арифметических действий с единицами измерения. В пособии сначала даётся таблица, а затем описывается методика работы с опорой на эту таблицу.

В связи с совершенствованием материально-технического оснащения современной школы у учителя появилась возможность использования опорных таблиц не только в статичном (на бумажных носителях или с помощью медиа-презентации), но и в динамичном режиме (посредством интерактивной доски, планшетного или персонального компьютера), когда обучающиеся под руководством учителя дополняют пустые столбцы и строки заданной таблицы или создают по опорным вопросам таблицу с «чистого листа». В этом случае интеллектуальная деятельность еще более активизируется, создаются возможности для более глубокого осмысления учебного материала и творческой переработки его содержания. 


\section{Гдава 1. ТАБДИЦЫ НА УРОКАХ РУССКОГО ЯЗЫКА}

\section{1. Таблицы для изучения раздела «Фонетика»}

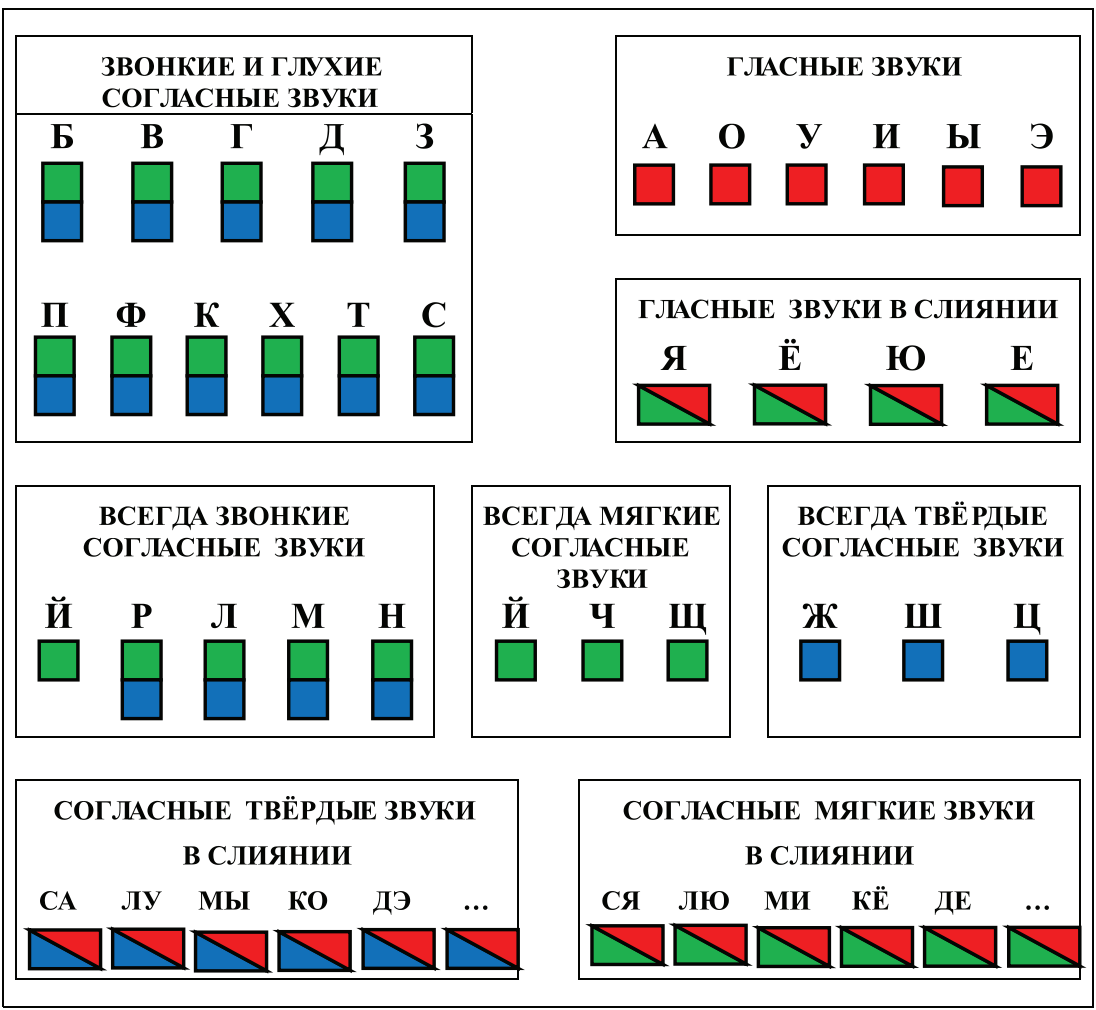

Рис. 1. Звуки речи

Примечание к таблице:

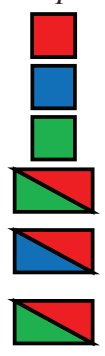

- гласный звук вне слияния (квадрат красного цвета);

- твёрдый согласный звук вне слияния (квадрат синего цвета);

- мягкий согласный звук вне слияния (квадрат зеленого цвета);

- гласный звук в слиянии (прямоугольник красно-зеленого цвета);

- согласный твёрдый звук в слиянии (прямоугольник красносинего цвета);

- согласный мягкий звук в слиянии (прямоугольник красно-зе-

леного цвета). 
На этапе объяснения темы учитель организует работу с верхней частью опорной таблицы (рис. 1). Обучающиеся читают двустишие, предварительно написанное учителем на доске:

В сад заглянули козы,

Остановились, увидев розы.

Учитель организует беседу с классом:

- Что вы прочитали? (Предложение).

- Почему вы так считаете? (Потому что мысль понятна и завершена).

- Из чего состоит предложение? (Из слов).

- Из чего состоит каждое написанное слово? (Из букв).

- А из чего состоит слово, которое мы произносим и слышим? (Из звуков).

- Найдите в этом стихотворении слова, которые различаются только одним звуком. (озы - озы).

Далее выясняется разница между этими словами по значению, произношению, делается вывод о важности каждого звука и каждой буквы в слове.

Учитель продолжает обсуждение:

- Произнесите отдельно каждый звук в слове игла и понаблюдайте, при произношении каких звуков воздух свободно проходит через рот, а когда встречает преграду.

- Как произносятся звуки $u, a$ ? Без голоса или с голосом?

- Как называются звуки, которые произносятся с голосом, и при их произнесении воздуху не мешают никакие преграды? (Гласные).

- Что вы еще знаете о гласных звуках? (С их помощью образуются слоги).

- Докажите, что гласный звук образует слог. (Обучающиеся приводят примеры и записывают под диктовку некоторые слоги).

Учитель указывает обучающимся на таблицу, разбирает группы звуков по таблице, дифференцирует их на гласные и согласные, звонкие и глухие, твёрдые и мягкие, обращает внимание на те согласные, которые всегда твёрдые (мягкие). При разборе букв гласных звуков акцентируется внимание на том, что некоторые буквы обозначают один гласный звук $(a, o, y, u, b l, \ni)$, и тогда они обозначаются значком в виде красного квадрата, а некоторые - два $(я, \ddot{e}, ю, e)$ - обозначаются красно-зеленым прямоугольником. Отдельно обговаривается, что буквы $я, e, \ddot{e}, ю, u$ еще обозначают мягкость согласных.

Учитель объясняет смысл слияния и его обозначения с помощью значков. Так, красно-синим прямоугольником обозначаются слияния согласного с гласным, в которых согласный перед гласным твёрдый (na-, мy-, лы и др.), а красно-зеленым - слияния, в которых согласный перед гласным мягкий (пя-, мю-, ли- и др.).

На этапе закрепления материала делается разбор посредством упражнений. Например, для усвоения роли йотированных гласных в словах 
проводится следующее упражнение: учитель называет разные слова, а дети делают выводы, почему в них пишется эта гласная:

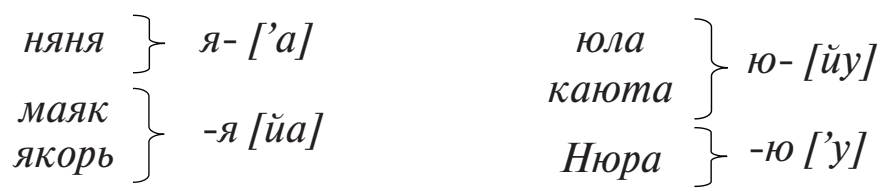

Закрепление изученного можно проводить с помощью игр. Например, учитель указывает на любой гласный в опорной таблице, а дети приводят примеры слов с этим звуком в той части(ях) слова, на которую(ые) укажет учитель:

Учитель: а $\rightarrow$ [a].

Обучающиеся: шар, арка...

Учитель: я $\rightarrow$ ['a].

Обучающиеся: мяч, няня....

Учитель: я $\rightarrow$ [й’а].

Обучающиеся: маяк, якорь...

На уроках закрепления изученного проводится работа с верхней частью таблицы «Звуки речи» (рис. 1). При этом учитель предлагает обучающимся вспомнить с опорой на таблицу, чем отличаются гласные звуки от согласных. (Гласные произносятся с голосом, а согласные с голосом и шумом или только с шумом).

Затем учитель предлагает загадки, а дети называют слово-отгадку, определяют в нем согласные звуки, дают им характеристику: глухой согласный произносится только с шумом, звонкий согласный - произносится с голосом и шумом, производят проверку правильности выделенных характеристик по глухости-звонкости. Параллельно отрабатываются такие характеристики, как твёрдость-мягкость.

\section{Пример:}

Учитель: Сооружение для перехода через реку (мост).

Обучающиеся: В этом слове три согласных звука: [м], [c] и [т];

[м] - звонкий, твёрдый;

[c] - глухой, твёрдый;

[т] - глухой, твёрдый.

На этапе закрепления материала активно используются игры. Приведем примеры.

Игра «Кто быстрее?»

Учитель указывает на звук в опорной таблице, а обучающиеся называют слова, в которых этот звук произносится именно так, как указано в таблице. Учитель может усложнить задание, дав инструкцию на поиск слов, в которых 
заданный звук стоит в начале, середине или конце слова. Выигрывает тот, который назвал больше всего слов.

\section{Игра «Лучшая память»}

Обучающиеся без опоры на таблицу выполняют следующие задания учителя:

1. Назовите согласные звуки, которые бывают только звонкими.

2. Назовите согласные звуки, которые бывают только мягкими.

3. Назовите твёрдые звонкие согласные.

4. Назовите мягкие глухие согласные.

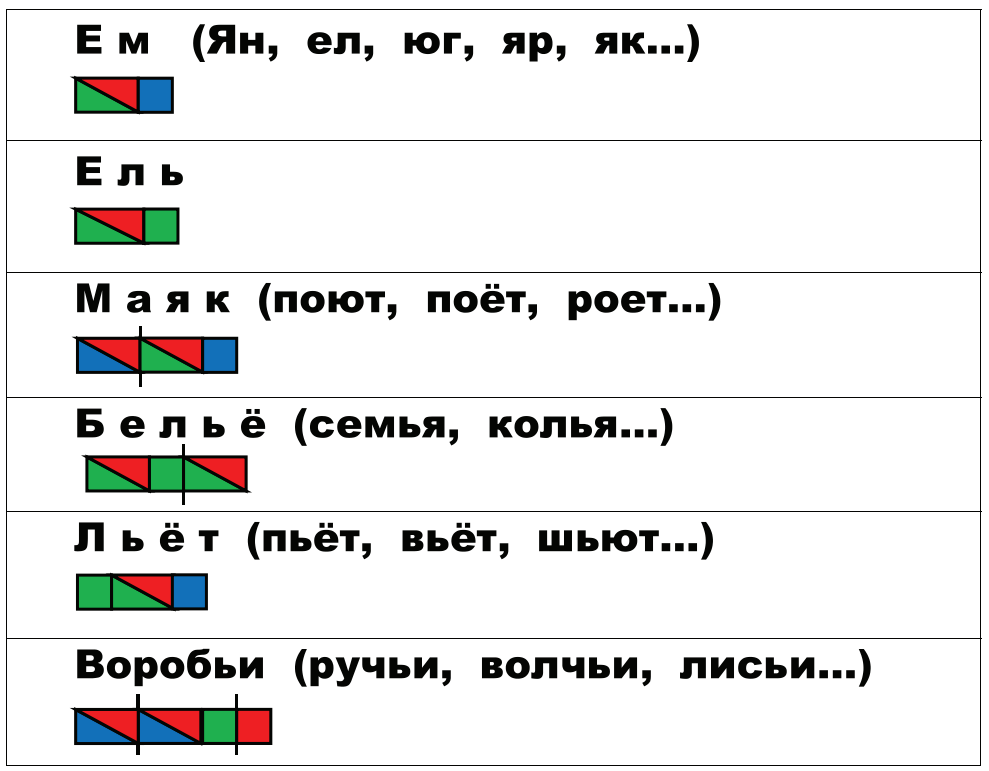

Рис. 2. Звуковой анализ слова

В процессе объяснения нового материала учитель предлагает обучающимся вспомнить, как схематично обозначаются разные звуки (используется таблица на рис. 1), а затем даёт образец звукового анализа слов с опорой на таблицу на рис. 2: «Ем [йээм] - три звука: $e$ - гласная буква в начале слова, даёт два звука в слиянии - [йэ]. Обозначаю слияние красно-зеленым прямоугольником, так как [й’] - мягкий согласный; [м] твёрдый согласный вне слияния, обозначаю его синим квадратом».

Учитель просит прочитать слова в таблице (рис. 2), которые будут иметь такую же схему в результате звукового анализа, что и слово ем (ел, Ян, юг, яр, як).

Аналогичным образом даётся образец звукового анализа других слов в таблице (ель, маяк, бельё, льёт, воробьи). 
В процессе закрепления материала обучающиеся самостоятельно с опорой на таблицу проводят звуковой анализ предложенных учителем слов. Можно провести следующие игры в виде соревнования:

- «Кто быстрее?» (побеждает тот, который за более короткий срок, чем остальные, сможет правильно провести звуковой анализ предложенного учителем слова);

- «Кто больше?» (побеждает обучающийся, который за отведенное время проведет звуковой анализ наибольшего количества слов из предложенных учителем);

- «У кого интереснее?» (побеждает ученик, который придумал и провел звуковой анализ самого длинного или редко встречающегося слова, выбранного им).

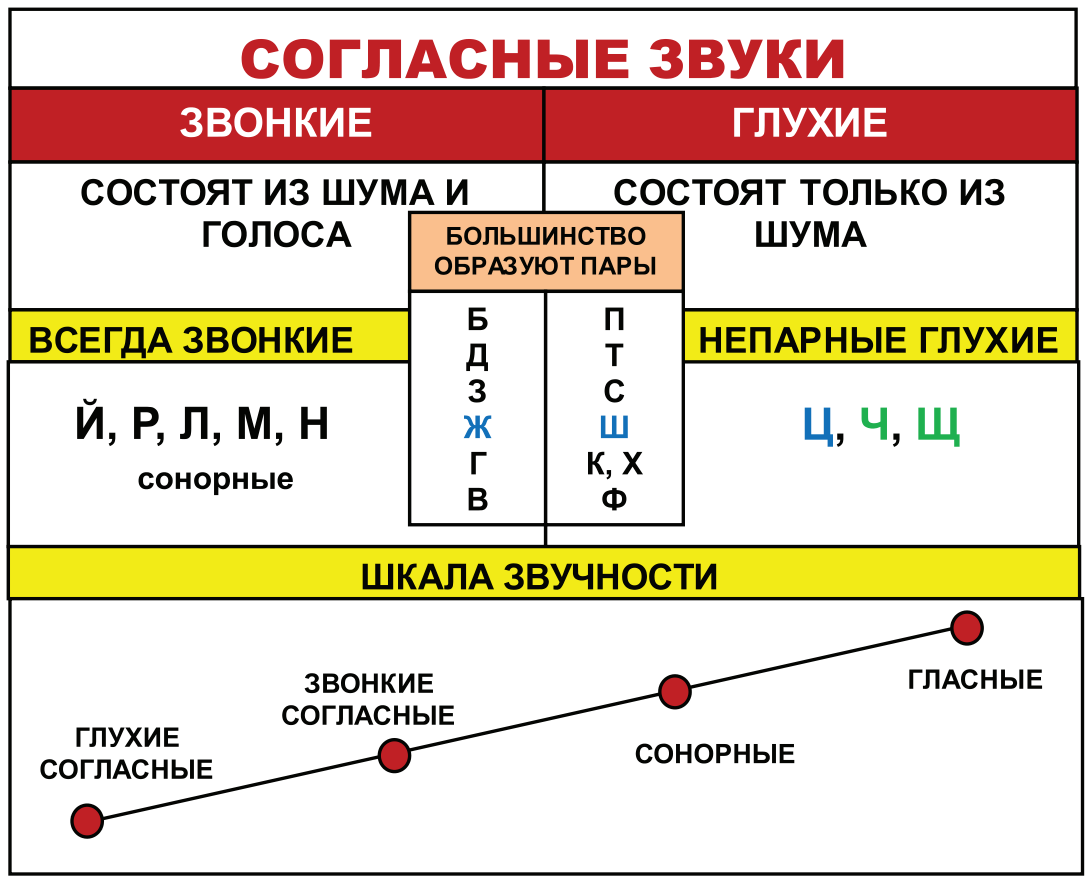

Рис. 3. Звонкие и глухие согласные

По таблице «Звонкие и глухие согласные» (рис. 3) дети учатся их различать.

Объяснение материала можно начать с опроса с опорой на ранее усвоенный материал.

- Чем отличаются согласные звуки от гласных? (Варианты ответа могут быть следующие: «Гласные можно пропеть, а согласные нет», «Гласные произносятся с голосом, а согласные или с шумом, или с шумом и голосом»). 
- Какие бывают согласные звуки? (Звонкие и глухие, парные и непарные, мягкие и твёрдые).

На этапе закрепления и обобщения материла можно запланировать отгадывание загадок с последующим звуковым анализом отгаданных слов, например:

1. Бывает апельсиновый, томатный, яблочный... (сок).

c - [c] - шум $\rightarrow$ глухой согласный;

о - [о-о-о] - $\rightarrow$ голос гласный;

$\mathrm{K}-[\mathrm{\kappa}]-$ шум $\rightarrow$ глухой согласный.

2. Что находится под дверью (порог)?

п - [п] - шум $\rightarrow$ глухой согласный;

o-[a] - голос $\rightarrow$ гласный;

$\mathrm{p}-[\mathrm{p}]-$ голос + шум $\rightarrow$ звонкий согласный;

$\Gamma-[\mathrm{k}]-$ шум $\rightarrow$ глухой согласный.

При анализе акцентируется внимание детей на том, что слышим $a$, а пишем $o$, слышим $\kappa$, а пишем г. При этом можно назвать проверочное слово, способствуя тем самым развитию орфографической зоркости.

В дальнейшем обучающиеся, называя слова, при помощи голоса и указки работают по шкале звучности (нижняя часть таблицы).

\begin{tabular}{|c|c|c|}
\hline \multirow{7}{*}{ парные } & Звонкие & Глухие \\
\hline & 5 & $\Pi$ \\
\hline & $\mathbf{B}$ & $\Phi$ \\
\hline & $\Gamma$ & $\mathbf{K}, \mathbf{X}$ \\
\hline & म & $T$ \\
\hline & X & UI \\
\hline & 3 & C \\
\hline Непарные & $\begin{array}{l}\text { Л, M, H, P, Й } \\
\text { (сонорные) }\end{array}$ & $\mathbf{x}, 4,4,4$ \\
\hline
\end{tabular}

Рис. 4. Парные и непарные согласные

По таблице «Парные и непарные согласные» (рис. 4) дети учатся отличать звонкие и глухие согласные, понимать правило замены звонкого согласного в середине и конце слова парным глухим согласным.

Объяснение нового материала можно начать с замены словосочетания одним словом или подбора синонимов к заданным словам, например:

1. Двенадцать месяцев (год) год - [гот].

2. Толкотня (давка) давка - [дафка] 
На основе таких примеров обучающиеся делают вывод о том, что такое парные согласные. С опорой на таблицу выделяются и перечисляются также и непарные звонкие и глухие согласные. Учитель делает акцент на том, что при письме необходима проверка парных согласных.

На этапе закрепления материала можно предложить следующие упражнения:

1) учитель приводит примеры слов со звонкими и глухими парными и непарными согласными, а обучающиеся с опорой на таблицу классифицируют их;

2) учитель читает текст, а дети находят слова, в которых есть парные согласные и производят их проверку;

3) проводится наблюдение за словами, в которых есть непарные звонкие согласные (сонорные) и непарные глухие согласные, делается вывод, что их не нужно проверять.

На последующих уроках можно также использовать таблицу при работе над ошибками в изложениях и диктантах. Необходимо также приучать детей использовать таблицу при проверке своей работы после фонетического разбора.

\section{ФОНЕТИЧЕСКИЙ РАЗБОР СЛОВА}

\section{Бук 2 гл., 4 согл., 7 букв, 6 зв. 6 [б] - согл., тв., звон. у [у] - гл., безуд. \\ к [к] - согл., тв., глух. \\ в [в] - согл., тв., звон. \\ a [a] - гл., Уд. \\ p [p'[ - согл., мягк., звон. \\ b - - -----}

Рис. 5. Фонетический разбор слова

Таблица на рис. 5 позволяет запомнить порядок фонетического разбора слова. Сначала учитель объясняет, как правильно сокращенно обозначать слова в процессе фонетического разбора: согласный - согл., гласный - гл., твёрдый - тв. и т. д., на примере слова «букварь» проводится фонетический разбор.

Далее даются варианты устного и письменного разбора слов. 


\section{Пример устного разбора}

Коньки: конь - ки, 2 слога, 2 гласных, 3 согласных звука, 6 букв, 5 звуков, ударный слог - ки. Пишу буквы $\kappa a, o$, эн, мягкий знак, $\kappa a, u$. Обозначаю звуки: [к], [а], [н'], [к'], [и]. Разбираю звуки: [к] - согласный, твёрдый, глухой...

Пример письменного разбора

Коньки -2 слога, 2 гл., 3 согл., 6 букв, 5 зв.

к $-[\mathrm{K}]-$ согл., тв., глух.

$\mathrm{o}-[\mathrm{a}]-$ гл., безуд.

н - [н'] - согл., мягк., звонк., сонорн.

ь --------

к - [к'] - согл., мягк., глух.

и - [и] - гл., уд.

Обучающиеся, производя такой фонетический разбор, комментируют его вслух (см. пример устного разбора) или про себя.

\section{2. Табдицы для изучения раздела «Части речи»}

\section{KTO? 4TO? ПРЕДМЕТ имя}

\section{существительное}

Рис. 6. Определение имени существительного

В процессе изучения нового с помощью таблицы «Определение имени существительного» (рис. 6) обучающимся даётся общее понятие о предмете и слове как названии предмета, ставятся вопросы к названиям предметов. Учитель объясняет, что еще выделяются конкретные и отвлеченные слова, обозначающие предмет, например книга (что?) - понятие, обозначающее конкретный предмет, горе (что?) - отвлеченное понятие. Затем учитель подводит класс к обобщению, что слово, обозначающее предмет, называется именем существительным. 
После этого идёт закрепление материала с помощью разнообразных видов работ, например занимательных заданий, которые не представлены в учебнике:

1. Учитель называет существительные. Девочки должны вставать из-за парт, когда слышат слова, которые отвечают на вопрос «кто?», а мальчики когда слышат слова, отвечающие на вопрос «что?».

2. Учитель загадывает детям загадки, а ответы вместе с обучающимися записывает на доске в два столбца: в первый столбец ответы с именами существительными, отвечающими на вопрос «кто?», а во второй столбец - на вопрос «что?». Примеры загадок:

Что пишет на доске, но очень пачкает пальцы (мел)?

Как называется ученическая сумка, которая находится за спиной (ранец)?

Финист - Ясный... (Сокол).

Резинка для стирания написанного - это... (ластик).

Злой огнедышащий змей - это... (дракон).

Кто выгнал лису из заячьей лубяной избушки? (Петух).

После этого можно перейти к выполнению заданий по учебнику с опорой на эту таблицу.

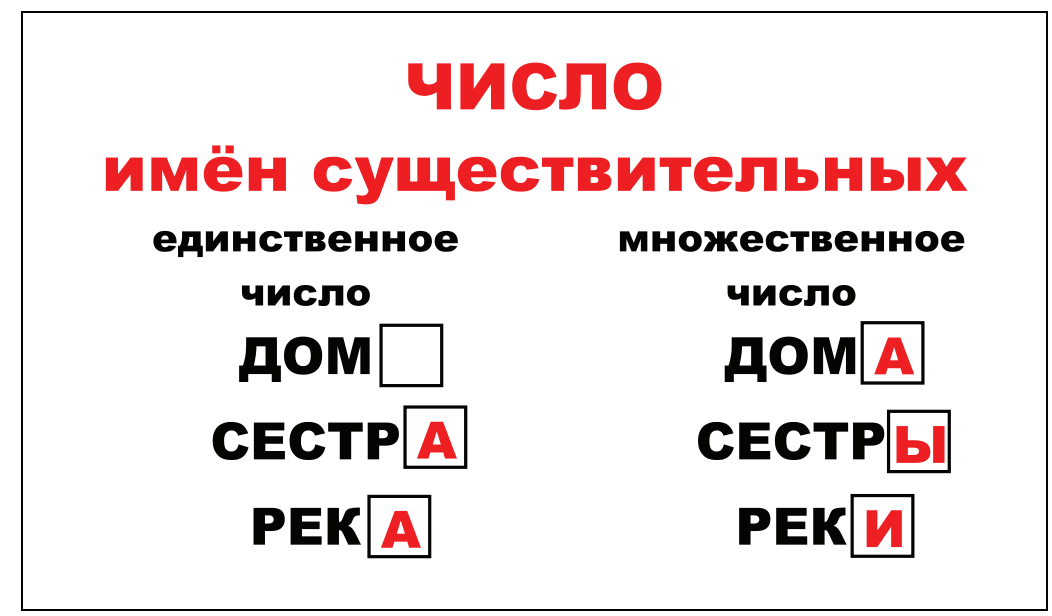

Рис. 7. Число имён существительных

Перед изучением нового материала учитель проводит подготовительную беседу с обучающимися:

- Вспомните, какие слова называют именами существительными? (Слова, которые отвечают на вопросы кто? и что?).

- Какие слова отвечают на вопросы кто? и что? (Слова, которые обозначают предметы). 
- Назовите конкретные предметы и поставьте к ним вопросы.

- Назовите слова-предметы, обозначающие явления природы (гроза, буря и др.).

- Назовите слова-предметы, обозначающие состояния человека (ycmaлость, грусть, гордость и др.).

Объяснение нового начинается с беседы:

- Кто? Мальчик. Какое количество предметов я назвала? (Один).

- Что? Озеро. Какое количество предметов я назвала? (Один).

- Попробуйте изменить эти существительные таким образом, чтобы они обозначали несколько предметов (мальчик - мальчики, озеро - озера).

- К какому выводу вы пришли? (Имена существительные изменяются по числам).

Внимание обучающихся обращается на таблицу «Число имён существительных» (рис. 7) и после объяснения того, как изменяются окончания при изменении слова по числам, учитель говорит, что в русском языке также есть существительные, которые употребляются только в единственном или только во множественном числе. Например, слова счастье, гордость и др. употребляются только в единственном числе, а слова ножницы, слив$\kappa u$ - только во множественном. Учитель поясняет, что подробнее об этом дети узнают в старших классах.

Далее учитель обращает внимание обучающихся на то, что формы единственного и множественного числа выражаются окончаниями и суффиксами $($ теленок - телята), окончаниями и чередованием звуков (ухо - уши) и т. д.

Закрепление изученного может проходить посредством выполнения разнообразных заданий.

\section{Упражнение «Группировка существительных»}

Обучающиеся записывают, комментируя, в 2 столбца слова, предложенные учителем: в первый столбец - слова единственного числа, во второй множественного. Например: «Береза (что?) - существительное в единственном числе, окончание $-a$. Пишем слово береза - в первый столбик», «Рыбы (кто?) - это существительное во множественном числе, окончание -ы. Пишем слово рыбы во второй столбик» и т. д.

\section{Физкультминутка}

Учитель называет имена существительные единственного и множественного числа. При назывании существительного единственного числа встает один ученик по цепочке, при назывании существительного во множественном числе - встает весь класс.

\section{Решение ребусов}

Обучающиеся решают ребусы, отгадками к которым являются существительные в единственном и множественном числе (рис. 8-10). Классу помимо отгадки следует с опорой на таблицу называть число и окончание отгаданного слова. 


\section{P 1 на}

Рис. 8. Ребус на отгадывание слова родина - существительного единственного числа с окончанием - $a$

\section{0 л}

Рис. 9. Ребус на отгадывание слова стол - существительного единственного числа с нулевым окончанием

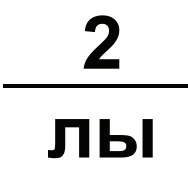

Рис. 10. Ребус на отгадывание слова подвалы - существительного множественного числа с окончанием -bl

Закрепление материала также проводится в процессе выполнения упражнений по учебнику (с опорой на таблицу).

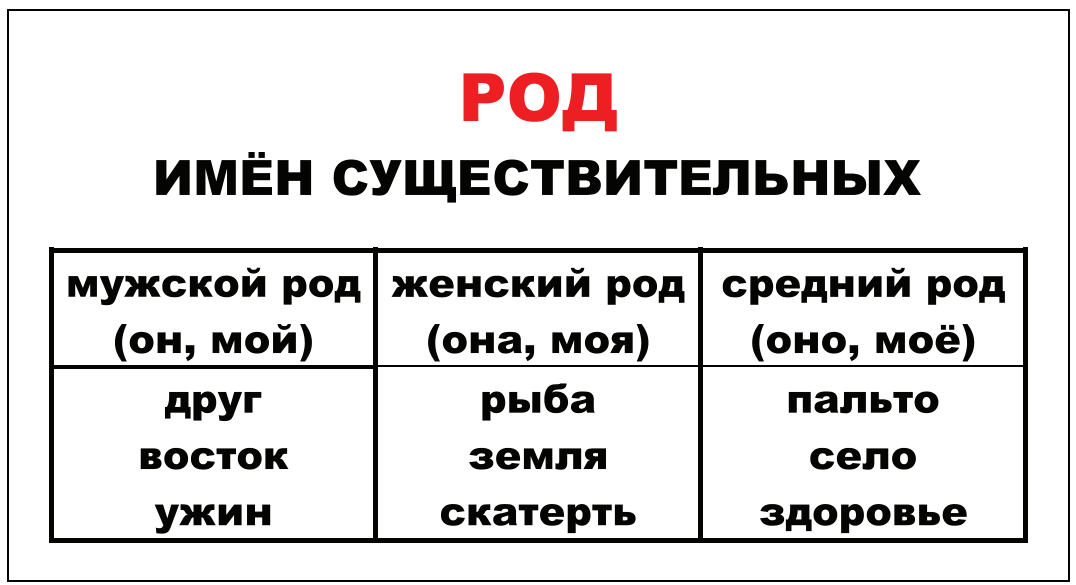

Рис. 11. Род и число разбор имён прилагательных 
Прежде чем начать работу по таблице «Род и число разбор имён прилагательных» (рис. 11), учитель проводит подготовительную работу:

- Прочитайте слова, написанные на доске (книга, таблица, море, озеро, платье, океан, конь).

- Что общего в этих словах? (Они обозначают предметы и являются именами существительными).

- К каким существительным подходят слова он, мой? (Он - океан, мой океан, он - конь, мой конь). Это существительные мужского рода.

- А к каким словам подходят слова она, моя? (Она - книга, моя книга, она - таблица, моя таблица). Это существительные женского рода.

- К каким существительным подходят слова оно, моё? (Оно - море, моё море, оно - озеро, моё озеро). Это существительные среднего рода.

Перед обучающимися открывается таблица (рис. 11), и они, изучая eе, проверяют сделанные выводы. Учитель знакомит обучающихся с сокращенной записью рода: мужской род - м. p., женский род - ж. р., средний род ср. p.

Объяснение материала проводится следующим образом:

- Прочитайте слова в первом столбце таблицы. Какие окончания у существительных м. р. (нулевые)?

- Какие окончания у существительных ж. р.? (- $a$, $-я$, мягкий знак на конце).

- Какие окончания у существительных ср. p.? (-o, -e).

- Можно ли у существительных м. р. заменить окончания и превратить их в существительные ж. р. и ср. p.? Попробуйте.

Школьники приходят к выводу, что каждое существительное в ед. ч. имеет свой определенный род, существительные по родам не изменяются.

Для закрепления материала предлагаются различные игры и упражнения.

Игра «Кто лучше?»

Обучающиеся соревнуются: кто лучше расскажет о роде существительных.

\section{Игра «Назови одним словом»}

Дети называют одним существительным словосочетания или целые предложения и определяют род у этих существительных:

1) жидкая грязь (жижа - ж. р.);

2) студень из фруктовых соков (желе - ср. р.);

3) друг Мартышки, Слонёнка и Попугая (удав - м. р.);

4) рыжий и усатый из сказки Корнея Чуковского (таракан - м. р.);

5) любимое занятие ребёнка (игра - ж. р.);

6) музыкальный инструмент с «языком» и верёвкой (колокол - м. р.). 


\section{ПАДЕЖИ}

\section{Именительный п. Родительный п. Дательный п. Винительный п. Творительный п. Предложный п.}

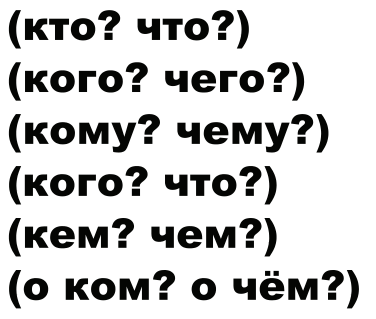
(кого? чего?) (кому? чему?) (коro? 4т0?) (кем? чем?) о ком? о чём?)

Рис. 12. Падежи русского языка

До показа опорной таблицы «Падежи русского языка» (рис. 12) учитель проводит подготовительную работу: показывает предметы, ставит вопросы, просит изменить слова, называющие эти предметы, и назвать окончания полученных форм существительных, например: книга - чего? - книги (окончание $-u)$. В процессе выполнения можно оформить запись на доске:

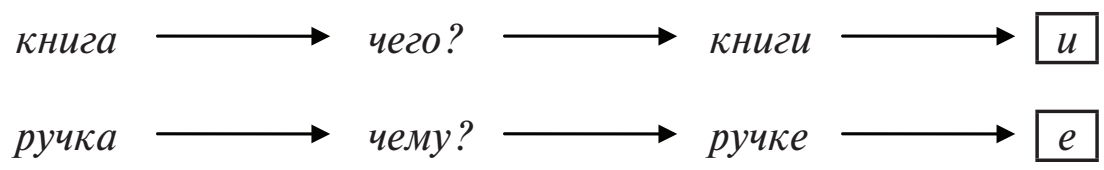

Учитель обращает внимание обучающихся на то, что окончания существительных изменяются в зависимости от вопросов, и проводит объяснение материала следующим образом: «Изменение окончаний существительных в зависимости от вопросов назвали изменением существительных по падежам или склонением существительных. В русском языке 6 падежей. С помощью падежей выражаются различные отношения между словами. Об этом подробнее вы узнаете в старших классах. Каждый падеж имеет своё название, своё значение, свои вопросы и свои окончания. От вопросов падежей зависит изменение формы слова. Посмотрите на таблицу (учитель обращает внимание на опорную таблицу «Падежи русского языка») и запомните названия и вопросы падежей. Для проверки правильности ваших ответов постоянно обращайтесь к этой таблице».

Обучающиеся под руководством учителя читают названия и вопросы падежей, а затем по очереди склоняют имена существительные по падежам (гроза, тетрадь, учебник, девочка и др.).

В качестве закрепления материала можно использовать различные игры и упражнения. 
Упражнение «Хоровое склонение»

Учащиеся хором склоняют по падежам слова окно и стол.

Игра «У кого лучше?»

Трое обучающихся, используя опорную таблицу, на скорость склоняют существительные по падежам у доски. По итогам выполнения задания определяется победитель.

В качестве средства закрепления изученного также используются упражнения из учебника.

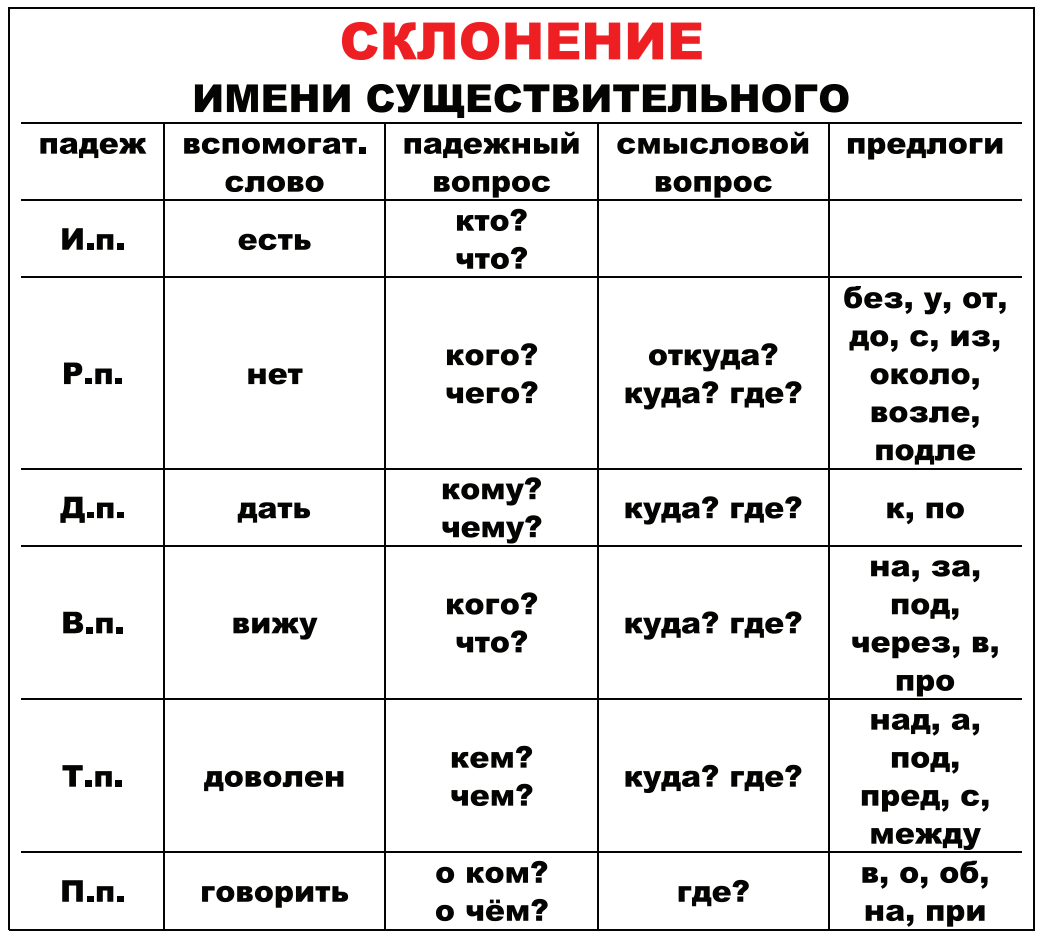

Рис. 13. Склонение имени существительного

Перед изучением нового материала учитель проводит подготовительную беседу:

- На прошлом уроке мы изучали изменение окончаний существительных по вопросам.

- Как это действие можно назвать по-другому? (Изменение существительных по падежам)?

- Сколько падежей в русском языке?

- Измените по падежам слова брат и бабушка. 
Далее учитель объясняет новую тему с опорой на таблицу (рис. 13).

Когда вы изменяете существительные по падежам, особенно существительные женского рода, вы часто затрудняетесь в изменении формы слова, а именно в выборе правильного окончания образованной формы слова. Почему это происходит? Посмотрите на третий столбец опорной таблицы, в котором указаны падежные вопросы. Мы ошибаемся там, где указаны одинаковые вопросы в разных падежах: в окончаниях именительного и винительного падежей, родительного и винительного падежей. Чтобы не ошибаться в склонении имён существительных, будем использовать вспомогательные слова, они указаны во втором столбце таблицы. А во время определения падежей существительных в предложениях будем опираться не только на основные падежные вопросы, но и на смысловые вопросы, которые вы видите в четвертом столбце, и предлоги, которые находятся в пятом столбце.

После объяснения учитель даёт обучающимся задания, направленные на закрепление материала - формирование умения склонять существительные, используя вспомогательные слова, предлоги и смысловые слова из таблицы.

\section{Задание 1}

Прочитайте вспомогательные слова во втором столбце таблицы. Просклоняйте существительное город, используя не только падежные вопросы, но и вспомогательные слова.

И. п. (есть что?) город.

Р. п. (нет чего?) города.

Д. п. (дать чему?) городу.

В. п. (вижу что?) город.

Т. п. (доволен чем?) городом.

П. п. (говорить о чём?) о городе.

Если действие усвоено недостаточно, упражнение можно повторить с другими словами.

Делается вывод о том, что при использовании вспомогательных слов склонять существительные без ошибок очень легко.

\section{Задание 2}

Просклоняйте существительное ручка, используя предлоги в пятом столбце таблицы.

Р. п. (без чего?) без ручкиㅡ, (у чего?) у ручкй, (около чего?) около ручкй и т. д.

Д. п. (к чему?) к ручке, (по чему?) по ручке.

В. п. (на что?) на ручку, (за что?) за ручку, (через что?) через ручку, (про что?) про ручку и т. Д.

Т. п. (над чем?) над ручкой, (под чем?) под ручкой, (перед чем?) перед ручкой и т. д.

П. п. (в чём?) в ручке, (на чём?) на ручке, (при чём?) при ручке и т. д.

Учитель обращает внимание детей на то, что при склонении с помощью предлогов все окончания существительных одной падежной формы одинаковые. 


\section{Задание 3}

Обучающиеся записывают предложения, диктуемые учителем, используя смысловые вопросы и обращая внимание на предлоги в опорной таблице.

На этапе закрепления материала могут быть использованы упражнения подобные описанным или другие задания, например, объяснительный диктант. Текст для диктанта выбирается по усмотрению учителя с опорой на уровень подготовленности обучающихся.

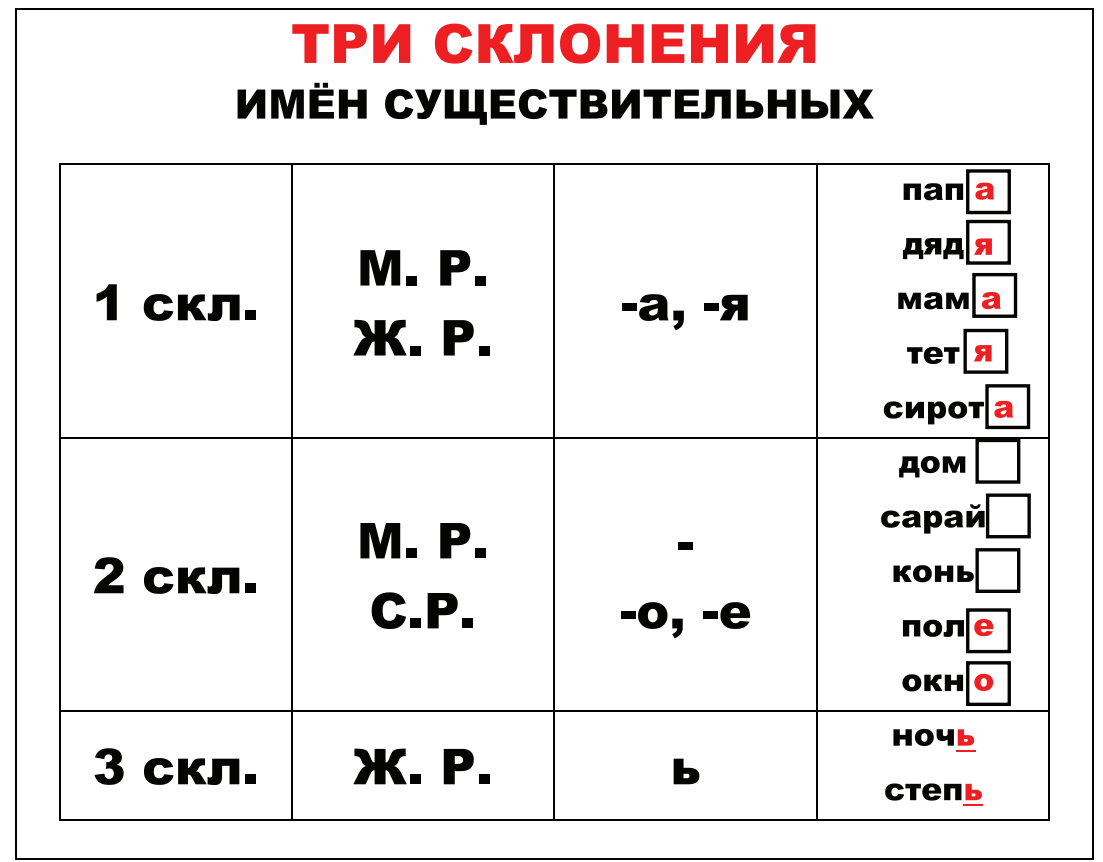

Рис. 14. Склонения имён существительных

В процессе подготовительной работы учитель делает запись на доске:

$\begin{array}{lll}\text { И. n. земля } & \text { диван } \\ \text { папа } & \text { озеро } \\ \text { дядя } & \text { герой }\end{array}$

По каждому из столбцов с существительными учитель задаёт следующие вопросы:

- Как склоняются существительные первого (второго, третьего) столбца?

- Какого рода эти существительные?

- В каких падежах эти существительные имеют одинаковые окончания? 
Далее учитель переходит к объяснению темы и, используя опорную таблицу (рис. 14), просит обучающихся сформулировать три вывода:

1) к первому склонению относятся существительные мужского, женского и общего рода с окончаниями $-a,-я$;

2) ко второму склонению относятся существительные мужского с нулевым окончанием и среднего рода с окончаниями -o, $-e$;

3) к третьему склонению относятся существительные женского рода с мягким знаком на конце.

Для закрепления материала учитель использует разнообразные приёмы.

\section{Упражнение «Письмо с комментированием»}

Учитель предлагает обучающимся существительные разных склонений, а они записывают и поочередно комментируют запись, например:

1) дедушка - существительное м. р. с окончанием - $a$, значит, это слово 1 скл.»;

2) речь - существительное ж. р., с мягким знаком на конце, значит, это существительное 3 скл.

\section{Физкультминутка}

Учитель называет существительные разного склонения. При назывании существительных первого склонения встает (или хлопают в ладоши) первый ряд, при назывании существительного второго склонения - второй ряд, при назывании существительного третьего склонения - обучающиеся третьего ряда. Правильность выполнения задания проверяется по опорной таблице.

\section{Игра «Кто быстрее и точнее»}

На доске записано 3 столбца с существительными разных склонений. Трое обучающихся соревнуются в определении склонения существительных.

\section{Диктант}

Дети пишут диктант, а затем по цепочке выбирают существительные из написанного текста и определяют их склонение, например: «К лодке. Начальная форма слова - лодка. Существительное ж. р. с окончанием - $a$, значит, слово лодка 1 скл.».

Учитель открывает перед классом таблицу (рис. 15) и объясняет матеpuaл: «Вы уже познакомились с тремя склонениями существительных. Выделите окончания существительных первого склонения по опорной таблице. Какие окончания у существительных 1 скл. в р. п.? В каких случаях пишем окончание -b, а в каких -u? (Если перед окончанием согласный звук произносится твёрдо, то пишем -ы, если мягко - пишем -u). В каких падежах окончания одинаковые? (В д. п. и п. п. - окончание -e). В каких случаях согласная перед окончанием мягкая? (В случаях, когда окончания падежных форм существительных $-я,-u,-e,-ю$, -ей). Почему в в. П. окончание или $-y$, или -ю? (Если согласный звук перед окончанием произносится твёрдо, то пишем $-y$, если мягко - пишем -ю). И т. д.». 


\section{ПЕРВОЕ СКЛОНЕНИЕ ИМЕНИ СУЩЕСТВИТЕЛЬНОГО}

И. п. Кто? что?

P. n. Koro? 4ero?

Д. п. кому? чему?

B. n. Koro? 4TO?

T. п. кем? чем?

п. п. о ком? о чём? сестр а, земла

сестр ы, земл и

сестре, земл e

сестр $\mathrm{y}$, земл

сестрой, земл ей

Рис. 15. Первое склонение имени существительного

На следующем этапе усвоения материала таблица закрывается, и учитель просит вспомнить окончание каждого падежа.

На этапе закрепления материала используются игры и упражнения.

Задание на определение падежа существительного по окончанию

Учитель показывает предметные картинки, названия которых являются существительными первого склонения, и просит образовать форму определенного падежа, выделяя окончание. Например:

\begin{tabular}{|c|c|c|}
\hline Картинка & Учитель & Обучающийся \\
\hline книга & в д. п.? & книгу, $-y$ \\
\hline тарелка & в п. п.? & о тарелке, $-e$ \\
\hline
\end{tabular}

Игра «Узнай падеж существительного 1 скл.»

Игра проводится при закрытой таблице.

\begin{tabular}{|l|c|}
\hline \multicolumn{1}{|c|}{ Учитель } & Обучающийся \\
\hline Окончание -е, 1 скл. с предлогом $\kappa$ & Д. п. \\
\hline Окончание -ой 1 скл. & Т. п. \\
\hline Окончание -ей 1 скл. & Т. п. \\
\hline И т. д. & \\
\hline
\end{tabular}

Упражнение «Просклоняй существительные»

Класс самостоятельно изменяет по падежам существительные первого склонения (корзина, дядя и др.). При необходимости в качестве опоры используется таблица. 
Упражннене «Письмо с проговариванием»

Обучающиеся пишут диктант и поочередно после написания каждого предложения определяют падеж и окончание существительных первого склонения.

1 скл., п. п. 1 скл., и. п. 1 скл., в. п.

В берлоге медведь $\square$ спит спокойно всю зим 1 скл., n.n. 1 скл., p. п.

возне возле берлоги он просыпается. Зверь долго бродит 1 cкл., p. n.

вокруг полян и и не может найти покоя. Он становится

onacHblM.

\section{ВТОРОЕ СКЛОНЕНИЕ \\ ИМЕНИ СУЩЕСТВИТЕЛЬНОГО}

И. п. Кто? что?

P. n. Koro? чero?

Д. п. кому? чему?

B. n. Koro? 4To?

T. п. кем? чем?

ก. п. о ком? о чём?

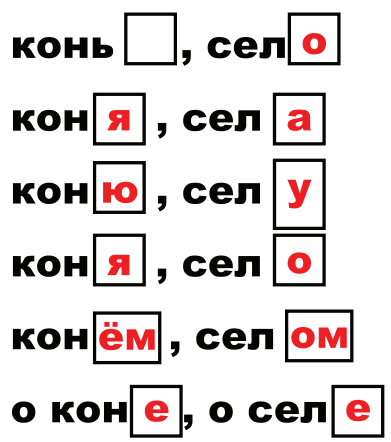

Рис. 16. Второе склонение имени существительного

В процессе подготовительной работы учитель проводит опрос обучающихся:

- Вспомните, какие склонения существительных мы изучали на прошлых уроках?

- Какие существительные относятся к первому склонению? Ко второму? К третьему?

- Вспомните, какие падежные окончания имеют существительные первого склонения.

- Просклоняйте существительное отец при помощи вспомогательных слов и падежных вопросов. 
- Просклоняйте существительное огород только при помощи падежных вопросов.

- Просклоняйте существительное отряд без вопросов, т. е. кратко.

При необходимости для выполнения задания предоставляется опорная таблица «Падежи русского языка» (рис. 12).

В процессе объяснения материала учитель обращает внимание обучающихся на таблицу (рис. 16) и проводит беседу по следующему плану:

- Какого склонения существительные в таблице? (2 скл.).

- Как это можно проверить? (У существительного мужского рода нулевое окончание, а у существительного среднего рода - окончание -о).

- В каких падежных формах существительных одинаковые падежные вопросы? (и. п. и в. п. - отвечают на вопрос «Что?», р. п. и в. п. - отвечают на вопрос «Кого?»).

При объяснении материала особое внимание обращается на то, что в родительном и винительном падежах совпадают окончания у существительных, обозначающих одушевленные предметы, а в именительном и винительном у существительных, обозначающих неодушевленные предметы. Утверждение предлагается проверить с помощью смысловых вопросов (см. таблицу «Склонение имени существительного»).

Учитель также отмечает, что существительное в именительном падеже является в предложении подлежащим, а в винительном - дополнением.

Для лучшего усвоения материала учитель организует следующее упражнение с опорой на таблицу: обучающиеся по цепочке изменяют существительное второго склонения (окно, лед и др.) по падежам, сравнивая его окончания с окончаниями слов, представленных в таблице (рис. 16).

Закрепление материала проводится посредством игр и упражнений.

Самостоятельное письмо

Учитель даёт задание самостоятельно просклонять слово стол. Один обучающийся работает у доски, остальные - в тетрадях. После выполнения задания можно сравнить работы детей.

Игра «Узнай падеж»»

Учитель даёт словосочетания с существительными второго склонения в разных падежных формах, например:

$$
\begin{aligned}
& \text { m. } n \text {. } \\
& \text { горжусь труд ом }
\end{aligned}
$$

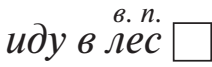

$$
\begin{aligned}
& \text { m. } n \text {. } \\
& \text { дышу воздух ом }
\end{aligned}
$$




\section{ТРЕТЬЕ СКЛОНЕНИЕ \\ ИМЕНИ СУЩЕСТВИТЕЛЬНОГО}

M. ก. Kто? 4то?

P. n. Koro? yero?

Д. п. кому? чему?

B. ח. Koro? पто?

T. п. кем? чем?

п. ก. о ком? о чём? мышь $\square$, дверь $\square$

мыш и, двер $и$

мыш $и$, двер $и$

мышь $\square$, дверь $\square$

мышью, дверью

о мыш и, о двер $и$

Рис. 17. Третье склонение имени существительного

В процессе объяснения материала учитель обращает внимание обучающихся на таблицу (рис. 17) и проводит следующую беседу:

- Посмотрите на опорную таблицу. Существительные мышь и дверь относятся к третьему склонению. Почему? (Существительные женского рода с мягким знаком на конце относятся к третьему склонению).

- Обратите внимание на слова мышь и нож. Что вы заметили? У существительных третьего склонения после шипящих пишется мягкий знак, а у существительных второго склонения, например, в словах нож, шалаш не пишется.

- Посмотрите внимательно на таблицу и скажите, в каких падежных формах при разных вопросах окончания у существительных третьего склонения единственного числа одинаковые. (В р. п., д. и п. п. окончание -u).

- Какие еще падежные формы существительных третьего склонения единственного числа совпадают? (И. п. и в. п. существительных с нулевым окончанием).

- Какой падеж остался «одиноким»? (Т. п. с окончанием -ю).

Работа по закреплению материала также проводится с опорой на таблицу.

Задание 1

Учитель просит обучающихся изменить по падежам существительные третьего склонения (печь, рожь и др.) с помощью вспомогательных слов и падежных вопросов. 


\section{Задание 2}

Просклоняйте существительные с помощью только падежных вопросов (тишь, глушь).

При выполнении этих заданий, помимо таблицы «Третье склонение имени существительного» (рис. 17), может быть использована таблица «Падежи русского языка» (рис. 12).

\section{Задание 3}

Просклоняйте существительные без помощи вспомогательных слов и падежных вопросов (ночь, речь).

Для лучшего усвоения материала учитель также может предложить обучающимся игру «Кто быстрее?». Она проводится со всем классом. При этом трое работают у доски, остальные - в тетрадях. Задание - изменить по падежам существительное третьего склонения по собственному выбору. В итоге выявляется победитель - тот, кто правильно и быстрее всех выполнил задание. Во время соревнования опорная таблица «Третье склонение имени существительного» закрывается.

\section{ПАДЕЖИ И ПАДЕЖНЫЕ ОКОНЧАНИЯ ИМЁН СУЩЕСТВИТЕЛЬНЫХ}

\begin{tabular}{|c|c|}
\hline падеж & 1 скл. \\
\hline и. п. & $-a,-я$ \\
\hline P. n. & -ы, -и \\
\hline Д. п. & $-e,-e$ \\
\hline B. n. & $-y,-10$ \\
\hline T. $\boldsymbol{n}$. & -ой, -ей \\
\hline n. n. & $-e,-e$ \\
\hline
\end{tabular}

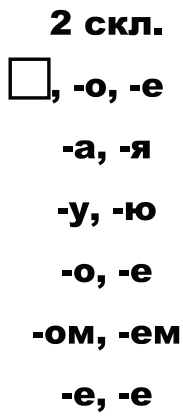

3 скл.

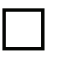

$-1$
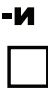

$-10$

$-4$

Рис. 18. Падежи и падежные окончания имён существительных

Опорная таблица «Падежи и падежные окончания имён существительных» (рис. 18) используется для углубления и закрепления изученного ранее 
материала по теме «Склонение имён существительных». Так, обучающимся предлагается устно просклонять существительные трёх склонений, сверяя окончания по таблице.

После этого упражнения учитель проводит опрос.

- Окончания каких падежных форм и склонений существительных одинаковые? (В д. п. и п. п. -1 скл., окончание - $е$; в и. п. и в. п. -2 скл., окончание $-о,-e$; в р. п., Д. П., П. п. -3 скл., окончание $-u)$.

- Какие окончания самые запоминаемые? (Окончания -ой, -ей, -ом, -ем т. п. 1 и 2 скл.)?

- В каких падежах существительные даже с безударным окончанием можно писать без ошибок? (В в. п. 1 скл. и в д. п. 2 скл. - окончания $-y,-ю)$.

- Давайте научимся писать безударные окончания трёх склонений без ошибок. Образуйте п. П. существительных 1 скл. книга и сестра

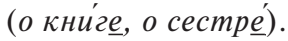

- Какие окончания в ударном и безударном положении у существительных 1 скл.? (Одинаковые).

- Образуйте п. п. существительных 2 скл. завод и конь. ( $О$ заводе, о коне́).

- Какие окончания в ударном и безударном положении у существительных 2 скл.? (Одинаковые).

- Образуйте п. П. существительных 3 скл. речь и рожь. (О речи́, о ржи').

- Какие окончания в ударном и безударном положении у существительных 3 скл.? (Одинаковые).

- Какой вывод можно сделать из этого? (Безударное окончание существительных 1, 2 и 3 скл. можно проверять подбором других существительных с ударными окончаниями того же склонения и в том же падеже).

Работа по закреплению материала может проводиться с помощью задания, состоящего из двух этапов.

Первый этап - образец учителя с комментированием: «В поду́шке - безударное окончание. Слышится то ли $-u$, то ли $-e$. Проверяю подбором существительного 1 скл. в п. п. с ударным окончанием - в стене́. Слышу на конце -e, значит в безударном положении в слове подушка пишу -е».

Bторой этап - письмо учащихся с комментированием по цепочке. Примерные слова: у ла́вки, на дива́не, у су́мки, в пена́ле, перед сте́нкой, в ре́чи.

После каждого объяснения обучающиеся сверяют свой ответ с опорной таблицей.

По таблице «Падежи и окончания имён существительных» (рис. 19), обучающимся еще раз предлагается запомнить окончания в р. п., д. п. и п. п. Именно в этих случаях дети чаще всего делают ошибки при письме. 


\section{ОКОНЧАНИЯ \\ ИМЁН СУЩЕСТВИТЕЛЬНЫХ}

\section{падеж}

P. n.

Д. п.

ก. $\mathbf{n}$.
1 скл.

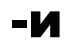

$-\mathbf{e}$

$-\mathbf{e}$
2 скл.

3 скл.

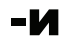

$-\mathbf{n}$

$-\mathbf{n}$

Рис. 19. Падежи и окончания имён существительных

Обучающимся сначала даётся возможность внимательно рассмотреть таблицу, сориентироваться в ней, а затем учитель делает беглый опрос по ней:

- Назовите падежи имён существительных 1 скл. с окончанием -e (д. п. и п. п.).

- Назовите падежи существительных 2 скл. с окончанием -e (п. п.).

- И т. д.

Для закрепления материала используются разнообразные игры и упражнения.

Ребусы и загадки

Задание - образовать из отгаданных слов существительные указанного падежа, устно выделить окончание; если оно безударное, найти проверочное слово.

Уиражнение «Проверочное письмо»

Обучающиеся пишут текст под диктовку учителя, с помощью опорной таблицы проверяя безударные окончания существительных единственного числа родительного, дательного и предложного падежей.

\section{Кто где живёт?}

В лесу каждый строит дом. В воздухе - дом у иволги. Она высоко над землёй подвесила к ве́тке берёзы корзинку из волосков и ше́рсти. В тра́кке - дом овсянки. Шалашик пе́ночки сделан из сухой травы. Бе́лке и синице уютно живётся на де́реве. Учо́мги - плавучее гнездо на воде. 


\section{МОРФОЛОГИЧЕСКИЙ РАЗБОР ИМЁН СУЩЕСТВИТЕЛЬНЫХ}

I - часть речи

II - начальная форма ( и. п., ед. 4.); собственное или нарицательное; одушевленное или неодушевленное; род и склонение; падеж, число

\section{III - член предложения}

Рис. 20. Морфологический разбор имён существительных

Прежде чем демонстрировать обучающимся опорную таблицу «Морфологический разбор имён существительных» (рис. 20), учитель просит написать в тетрадях предложение «Земля пахнет талым снегом», а затем проводит подготовительную беседу:

- Найдите в этом предложении существительные (земля, снегом).

- Напишите слово снегом. С каким словом в предложении связано слово снегом? Как это проверить? (Пахнет чем? Снегом).

- Что обозначает слово снегом? (Предмет).

- Какая начальная форма слова снегом? (Снег).

- Существительное снег - имя собственное или нарицательное? Одушевленное или неодушевленное?

- Определите род слова снегом (м. р.). Какого оно склонения? (2 скл.). В каком оно падеже? (Т. п.). Какого числа? (Ед. ч.).

- Каким членом предложения является слово снегом? (Дополнением).

В итоге учитель говорит, что они произвели морфологический разбор слова снег как части речи, и оформляет это письменно на доске, а обучающиеся - в тетради. Далее идёт объяснение новой темы с опорой на таблицу (рис. 20). Объясняя порядок морфологического разбора, учитель также обучает детей правильному сокращению слов при письменном морфологическом разборе.

После этого производится письменный разбор другого существительного в предложении - земля: «Земля (что?) - сущ., нач. ф. - земля, нариц., неодуш., ж. р., 1 скл., и. п., ед. ч., подлежащее, связано со словом пахнет». 
В качестве примера может быть также продемонстрирована таблица с морфологическим разбором существительного выставка (рис. 21).

\section{Был на выставке.}

I - (на) выставке, был на (чём?) выставке, имя сущ.

I - выставка; нариц.; нөдуш.; ж. р.; 1 скл.; п. п.; ед. ч.

III - был (где?) на выставке - обстоятельство

Рис. 21. Морфологический разбор существительного выставка

С целью закрепления и обобщения материала учитель предлагает для морфологического разбора другие предложения, выполняет с обучающимися упражнения по учебнику и т. д.

\section{какой? какая? какое? какие? ПРИЗНАК имя}

\section{прилагательное}

Рис. 22. Определение имени прилагательного 
Таблица «Определение имени прилагательного» (рис. 22) позволяет познакомить обучающихся со значением слов, отвечающих на вопросы «какой?», «какая?», «какое?», «какие?», и их ролью в речи человека.

Объяснение материала начинается с увлекательной игры, позволяющей привлечь внимание класса к новой теме, например с игры «Угадай-ка». При этом учитель загадывает загадки, написанные на доске, и организует разбор слов, которые обозначают признаки предмета.

\section{Примеры:}

- Быстрый, гладкий, круглый, накололся он на гвоздь - и нет его. Что это? (Шар). Какие слова в загадке дают подсказку о том, что это шар? Что они обозначают? (Признаки шара).

- Тонкая и острая, носом путь себе ищу, за собою хвост тащу (игла). По каким признакам вы узнали иглу?

- Круглое, красное, с дерева упало - Любе в рот попало (яблоко). По каким признакам вы узнали, что это яблоко?

- Сильные, стальные, всем помогают - режут, а себе не оставляют (ножницы). По каким признакам вы узнали, что это ножницы?

Далее учитель просит детей задать вопросы от слов «шар», «игла», «яблоко» и «ножницы» к их признакам: «Мяч какой?», «Игла какая?», «Яблоко какое?», «Ножницы какие?». В итоге он подводит обучающихся к выводу посредством вопроса: «На какие вопросы отвечают слова, обозначающие признаки предметов?», указывает на таблицу (рис. 22) и говорит, что такие слова называют именами прилагательными.

Далее идёт работа по закреплению изученного с опорой на эту таблицу в следующей последовательности:

1) учитель показывает предметы (или картинки с изображением предметов), дети называют их признаки, а один из ребят указывает на соответствующие этим признакам вопросы на таблице;

2) учитель называет прилагательные в начальной форме. При назывании предметов, отвечающих на вопрос «Какой?», встают дети первого ряда, «Какая?» - второго ряда, «Какое?» - третьего, «Какие?» весь класс. При ошибках учитель обращает внимание обучающихся на таблицу;

3) ребята выполняют задания на подбор признаков предметов: учитель просит угадать, как называется сосуд для молока (кувшин), а обучающиеся подбирают названия признаков предмета к угаданному слову: «Кувшин какой по цвету (высоте, материалу и т. д.)?»;

4) дети выполняют упражнения по учебнику с опорой на таблицу с различной степенью самостоятельности - в зависимости от уровня усвоения материала. 


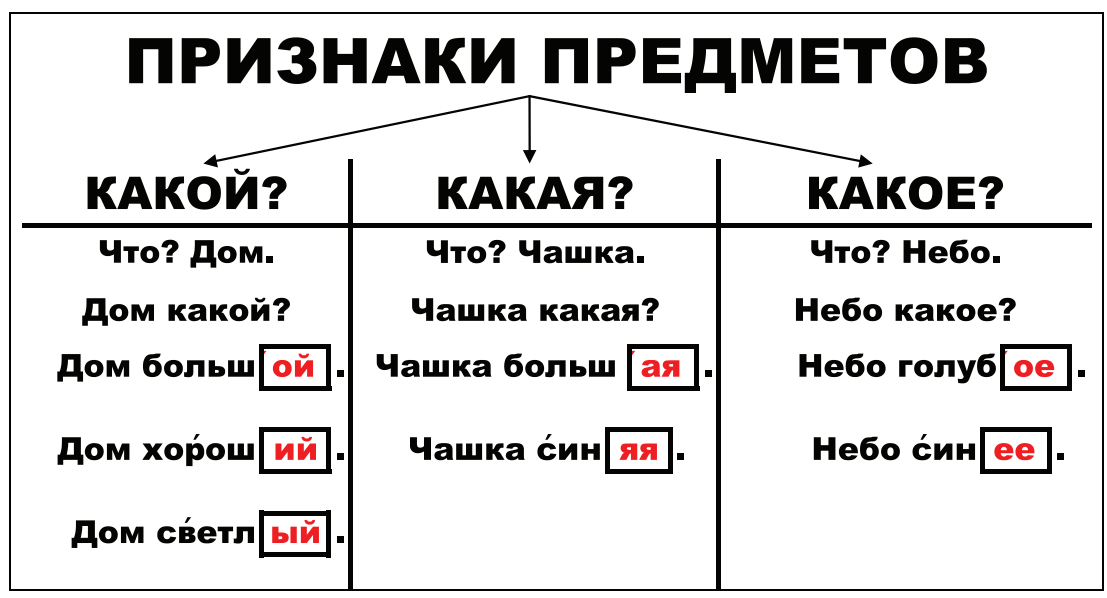

Рис. 23. Имя прилагательное (признаки предметов)

Подготовка к работе по опорной таблице «Имя прилагательное (признаки предметов)» (рис. 23) проходит в форме следующей беседы:

- Какой частью речи мы обозначаем предметы вокруг нас? (Именами существительными).

- Давайте научимся лучше представлять предметы. Например, перед вами находится предмет - мой стол. Какой он по форме? (Прямоугольный). Какой он по цвету? (Коричневый). Из какого он материала? (Из дерева). Значит, какой он? (Деревянный). Какого размера стол? (Большой). Какой формы стол может быть еще? (Круглый, квадратный, овальный). И т. д.

- Какой вывод из сказанного мы можем сделать? (У каждого предмета есть свои признаки формы, цвета, размера и т. д.).

- Слова, которые обозначают признаки предметов, назвали именами прилагательными. Как вы думаете, почему? (Потому что их можно присоединять к существительным). Правильно, их можно присоединять или, по-другому, прилагать к существительным. Вот и получились прилагательные.

- Давайте сформулируем вывод по сказанному. (Слова, которые обозначают признаки предметов, называются именами прилагательными).

- Подумайте, почему мы употребляем в речи слова, обозначающие признаки предметов. (Они делают нашу речь точнее, ярче и интереснее).

- Посмотрите на таблицу (рис. 23). На какие вопросы отвечают имена прилагательные? (Какой? Какая? Какое?).

- С существительными какого рода и числа связаны прилагательные? (М. р., ж. р., ср. р. в ед. ч.)? 
Далее учитель обращает внимание обучающихся на разные окончания имён прилагательных, подводит к выводу о том, что на вопрос «Какой?» в ударных окончаниях прилагательных пишется -ой, в безударных перед твёрдым согласным пишется -ый, а перед мягким согласным и шипящим - -ий.

Таким же образом разбираются окончания прилагательных ж. р. и ср. p. в ед. ч.

В качестве средства закрепления усвоенного могут быть предложены игры.

Игра «Кто лучше?»

Три ученика у доски соревнуются в лучшем объяснении правильного написания окончаний прилагательных м. р., ж. р. и ср. р. ед. ч. При этом они, в отличие от остальных обучающихся класса, не имеют возможности видеть опорную таблицу. При ошибочных ответах одноклассники исправляют ошибки соревнующихся. В итоге выявляется победитель.

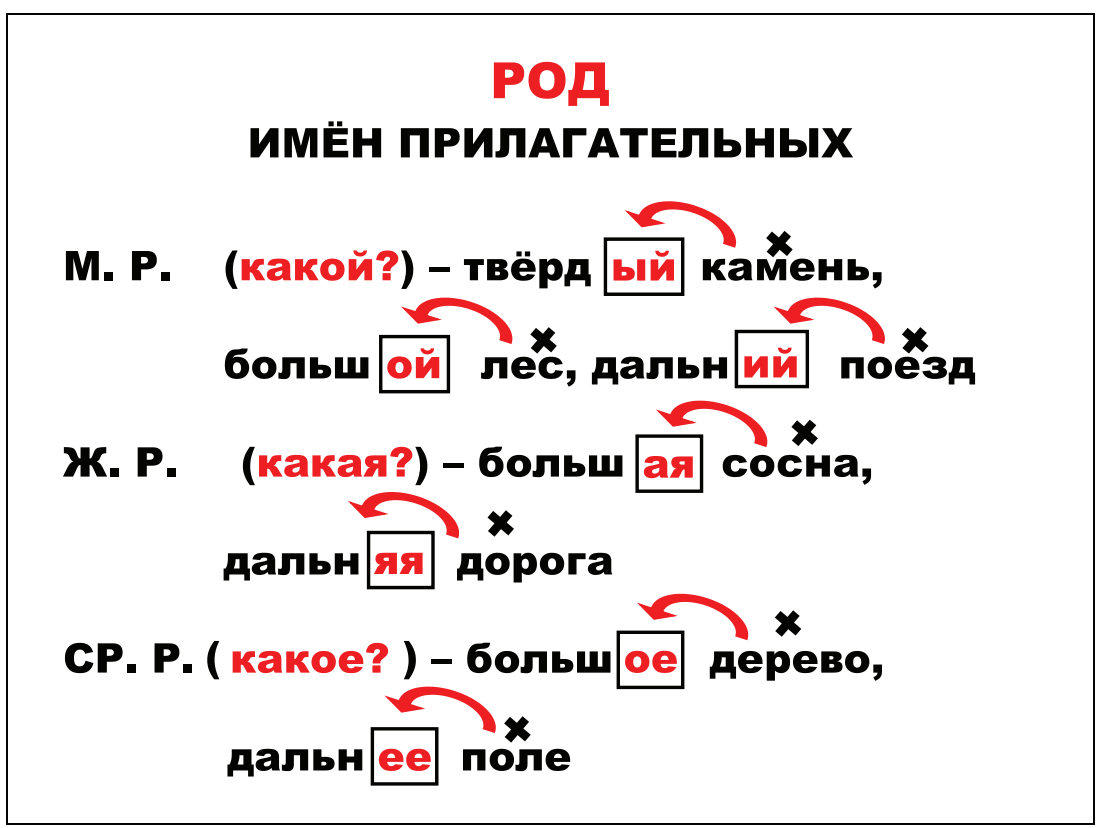

Рис. 24. Род имён прилагательных единственного числа

Игра «Узнай окончание»

Учитель называет окончания, а обучающийся, который не имеет возможность видеть опорную таблицу, называет, в каких формах имён прилага- 
тельных используется эти окончания. Остальные, опираясь на таблицу, контролируют правильность ответа одноклассника.

\begin{tabular}{|l|c|}
\hline \multicolumn{1}{|c|}{ Учитель } & \multicolumn{1}{|c|}{ Обучающийся } \\
\hline Окончание -яя & Ед. ч., ж. р. согласный перед окончанием произносится мягко. \\
\hline Окончание -ой & Ед. ч., м. р., окончание под ударением, ед. ч., ж. р., р., д., т. п. \\
\hline И т. д. & \\
\hline
\end{tabular}

В процессе объяснения новой темы учитель демонстрирует классу таблицу «Род имён прилагательных единственного числа» (рис. 24) и проводит следующую беседу:

- Прочитайте словосочетания в таблице. Какие словосочетания даны? (Прил. + сущ.).

- Камень какой? (твёрдый). Найдите главное слово (камень). Найдите зависимое слово (твёрдый).

- Какой частью речи является слово камень? (Существительное).

- Какого рода и числа имя существительное камень? (М. р., ед. ч.).

- А в каком роде и числе стоит зависимое прилагательное? (М. р., ед. ч.).

Таким же образом разбираются и другие словосочетания в таблице. В peзультате работы с таблицей обучающиеся делают следующие выводы:

1) в словосочетаниях зависимое прилагательное всегда того же рода, что и существительное (упоминается, что при этом слова в словосочетании должны быть в ед. ч.);

2) в окончаниях прилагательных м. р. под ударением пишется -ой, без ударения - -ый или -ий. В случае, если перед окончанием твёрдый согласный, то пишется -ый, а если мягкий, то -ий.

3) в окончаниях прилагательных ж. р. пишется -ая, если перед окончанием стоит твёрдый согласный, -яя - если перед окончанием мягкий согласный;

4) в окончаниях прилагательных ср. р. пишется -ое, если перед окончанием стоит твёрдый согласный, -ее - если перед окончанием мягкий или шипящий согласный.

С целью закрепления изученного используются различные задания. Например: учитель называет или показывает предметы, а ребята подбирают к названиям этих предметов прилагательные, называют, какие у них окончания, и аргументируют свой ответ.

Учитель: книга какая?

Обучающиеся: интересная, окончание -ая, т. к. существительное книга и прилагательное интересная ж. р., а перед окончанием твёрдый звук $H$. 


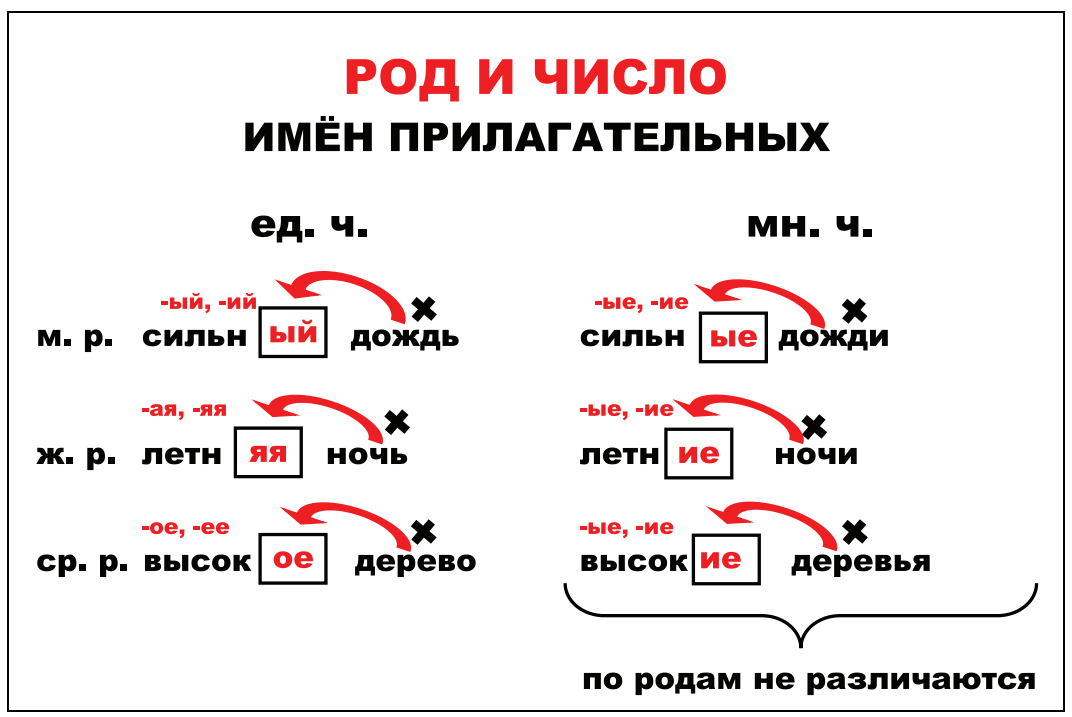

Рис. 25. Род и число имён прилагательных

Работу по таблице «Род и число имён прилагательных» (рис. 25) можно начать без подготовительной работы.

Объяснение материала проводится в следующей последовательности:

- Прочитайте пары слов каждого столбца. Чем они являются (словосочетанием)? Докажите. (Что? Дождь. Дождь какой? сильный. Дождь - главное слово. Это сущ., м. р., ед. ч. Сильный - зависимое слово м. р.).

- Вспомните, когда у прилагательных м. р., ед. ч. окончание -ый (-uй, -ой).

- Сформулируйте это словосочетание так, чтобы существительное и прилагательное были во мн. ч.

Таким же образом разбираются остальные словосочетания таблицы, после чего учитель спрашивает:

- Что интересного вы заметили в случае, когда существительное и связанное с ним прилагательное находятся во мн. ч.? (У всех родов прилагательных в форме мн. ч. одинаковые окончания - -ые, -ие).

- В каких случаях в окончаниях прилагательных пишем -ые, а в каких -иe? (Если перед окончанием твёрдый согласный, то пишем -ые, а если мягкий или $ж, ш$, то пишем -ие).

Приведем примеры игр и упражнений по закреплению материала.

\section{Игра «Узнай окончание»}

Учитель называет окончания имён прилагательных, а обучающиеся называют число прилагательного и объясняют, почему пишется именно это окончание. 


\begin{tabular}{|l|l|}
\hline \multicolumn{1}{|c|}{ Учитель } & \multicolumn{1}{c|}{ Обучающийся } \\
\hline Окончание -ые & $\begin{array}{l}\text { Окончание мн. ч., согласный произносится перед окон- } \\
\text { чанием твёрдо. }\end{array}$ \\
\hline Окончание -ее & $\begin{array}{l}\text { Окончание ед.ч., ср. р. в и. п. согласный произносится } \\
\text { перед окончанием мягко. }\end{array}$ \\
\hline И т. д. & \multicolumn{2}{|c|}{} \\
\hline
\end{tabular}

Упражнение «Письмо с комментированием»

Дети находят словосочетания прилагательное + существительное в тексте, выделяют окончание прилагательного, определяют, ударное оно или безударное, определяют род существительного и прилагательного и делают вывод о том, что определить род прилагательного можно по роду существительного, с которым оно связано.

\section{Примерный текст}

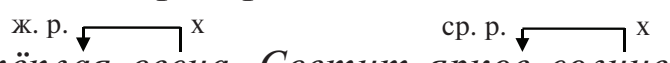

Пришла тёплая весна. Светит яркое солнце. С крыш ж. p.

мн. ч.

падает частая капель. На земле огромные лужи.

\section{СКЛОНЕНИЕ \\ ИМЁН ПРИЛАГАТЕЛЬНЫХ ВО МНОЖЕСТВЕННОМ ЧИСЛЕ}

и. п. ка́кие? -ые, -ие (горы, герои, поля, ночи)

Р. п. как их ? -ых, -их (гор, героев, полей, ночей)

Д. п. как им? -ым, -им (горам, героям, полям, ночам)

В. п. как ие? -ые, -ие (горы, героев, поля, ночи)

T. п. каикими? -ыми, -ими(горами, героями, ночами, полями)

п. п. о как их ? -ых, -их (горах, героях, ночах, полях)

Рис. 26. Склонение имён прилагательных во множественном числе 
При объяснении темы по таблице на рис. 26, учитель проводит следующую беседу:

- Вспомните, в каком случае существительные в русском языке не различаются по склонениям. (В случае, если это существительные мн.ч.).

- Какое число у существительных горы, герои, поля, ночи? (Мн. ч.).

- Назовите склонение этих существительных в ед. ч. (Гора -1 скл., поле -2 скл., ночь -3 скл.).

- Свяжите эти существительные одним прилагательным. (Горы, поля, ночи - красивые).

- Попробуем просклонять прилагательное красивое во мн. ч.

$$
\begin{array}{ll}
\text { И.п. } & \text { горы (какие?) - красивые } \\
& \text { поля (какие?) - красивые } \\
& \text { ночи (какие?) - красивые } \\
\text { P.п. } & \text { гор (каких?) красивых } \\
& \text { полей (каких?) красивых } \\
& \text { ночей (каких?) красивых } \\
& \text { и т.д. }
\end{array}
$$

- В каких падежах мн. ч. окончания прилагательных одинаковые? (В и. п. и в. п., в р. п. и п. п.)?

- В каких падежах мн. ч. окончания прилагательных различаются? (В д. П. и т. п.)?

- Что еще интересного вы заметили? (У прилагательных всех трёх склонений во мн.ч. окончания в д. п., т. п. и п. п. одинаковые).

- Просклоняйте словосочетании серые камни и серые мыши. Что вы заметили? (Когда существительное обозначает неодушевленный предмет, окончания связанного с ним прилагательного в и. п. и в. п. совпадают. Если существительные обозначают одушевленный предмет, связанное с ним прилагательное имеет одинаковые окончания в р. п., в. п. и п. п.).

В процессе закрепления материала обучающимся даются задания, которые выполняются с опорой на таблицу.

\section{Задание 1}

Устно просклонять словосочетание хорошее дело. При этом используются вспомогательные слова и падежные вопросы. (При необходимости используется и опорная таблица «Склонение имени существительного по падежам»см. рис. 13).

\section{Задание 2}

Просклонять только прилагательные без опоры на вспомогательные слова и падежные вопросы. 


\section{Задание 3}

Учитель произносит словосочетания (прилагательное + существительное) в разных падежах, обучающиеся определяют падеж прилагательного, например: в красивых домах (п. п.), у кирпичных стен (р. п.) и др.

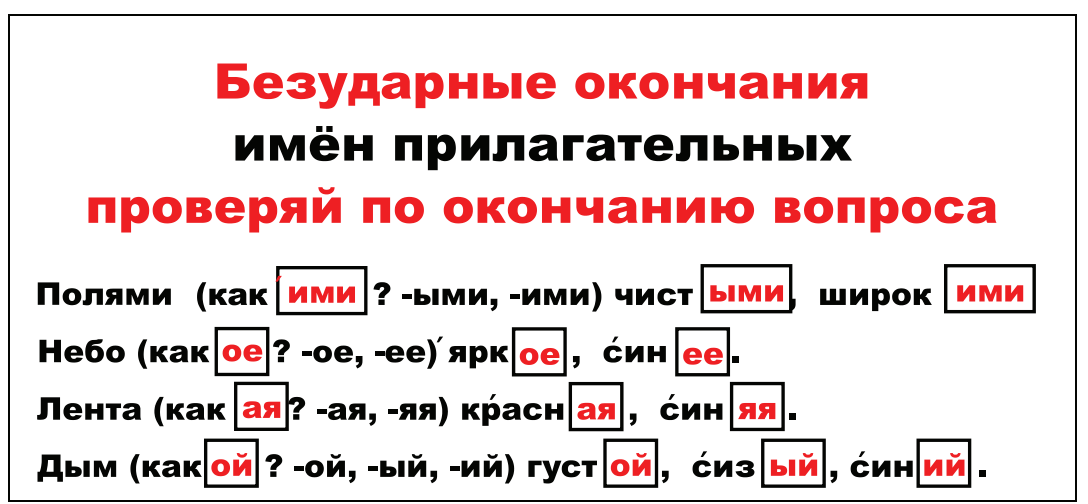

Рис. 27. Правило проверки окончания имён прилагательных

В процессе объяснения материала учитель предлагает изучить опорную таблицу «Правило проверки окончания имён прилагательных» (рис. 27) и ответить на следующие вопросы:

- Что написано в каждой строке? (Словосочетание).

- Какая часть речи в словосочетаниях является главным словом? (Существительное).

- Какая часть речи зависит от существительного? (Имя прилагательное).

- Полями какими? Чистыми. Широкими. Какое окончание у вопроса «Какими?»? (-ими). А какие окончания у прилагательных чистыми, широкими? (-ыми, -ими).

- Когда мы пишем окончание -ыми, а когда - -ими? (Когда перед окончанием прилагательного звук произносится твёрдо, то пишем -ыми, а когда мягко, пишем -ими).

Такая же работа проводится и по другим словосочетаниям таблицы. В итоге учитель подводит обучающихся к выводу, что безударные окончания прилагательных можно проверять по окончанию вопроса, которое всегда стоит под ударением. Этот вывод сравнивается с формулировкой правила в учебнике.

Закрепление изученного проводится посредством разных игр и упражнений. Приведем в качестве примера одну из игр.

Игра «Предметы вокруг нас»

Учитель показывает какой-либо предмет (или его изображение), просит назвать его и связать название с подходящим прилагательным в указанном падеже и числе, выделить и проверить окончание. 
Глава 1. Таблицьы на уроках русского языка

\begin{tabular}{|l|l|}
\hline \multicolumn{1}{|c|}{ Учитель } & \multicolumn{1}{|c|}{ Обучающийся } \\
\hline Стол в п. п. & $\begin{array}{l}\text { На столе (каком?) высоком. У вопроса окончание -ом, } \\
\text { у прилагательного окончание тоже -ом, т. к. звук к произ- } \\
\text { носится твёрдо. }\end{array}$ \\
\hline Парта в в. п. & $\begin{array}{l}\text { Парту (какую?) высо́кую. У вопроса окончание -yю, } \\
\text { у прилагательного окончание тоже -yю, т. к. звук перед } \\
\text { окончанием произносится твёрдо. }\end{array}$ \\
\hline Яблоко в т. п. & $\begin{array}{l}\text { Яблоком (каким?) вку́сным. У вопроса окончание -им, а } \\
\text { у прилагательного -ыл, т. к. согласная перед окончанием } \\
\text { произносится твёрдо. }\end{array}$ \\
\hline Василёк в р. п. & $\begin{array}{l}\text { Василька (какого?) синего. У вопроса окончание -ого, а } \\
\text { у прилагательного -его, т. к. согласный н перед окончани- } \\
\text { ем произносится мягко. }\end{array}$ \\
\hline И т. д. & \multicolumn{2}{|l}{} \\
\hline
\end{tabular}

\section{МОРФОЛОГИЧЕСКИЙ РАЗБОР ИМЁН ПРИЛАГАТЕЛЬНЫХ}

I - часть речи

II - начальная форма (и. п., ед. 4.); род (только в ед. ч.); падеж, число

\section{III - член предложения}

Рис. 28. Морфологический разбор имён прилагательных

Перед объяснением новой темы учитель проводит подготовительную работу, в процессе которой опорная таблица «Морфологический разбор имён прилагательных» (рис. 28) закрыта.

- Вспомните, что такое морфологический разбор имени существительного? (Это разбор существительного как части речи).

- По какому плану мы разбираем существительное? (При необходимости предоставляется опорная таблица «Морфологический разбор имён существительных»- см. рис. 20). 
Далее учитель даёт обучающимся возможность изучить опорную таблицу (рис. 28) и организует объяснение материала:

- Похож ли план разбора прилагательного на план разбора существительного? (Похож, но есть отличие: прилагательное согласовано с существительным и является определением).

Далее учитель предлагает детям письменно провести морфологический разбор прилагательных в предложении Над маленьким городом раскинулась разноцветная радуга.

При этом в качестве примера морфологического разбора прилагательного также может быть также продемонстрирована таблица на рис. 29.

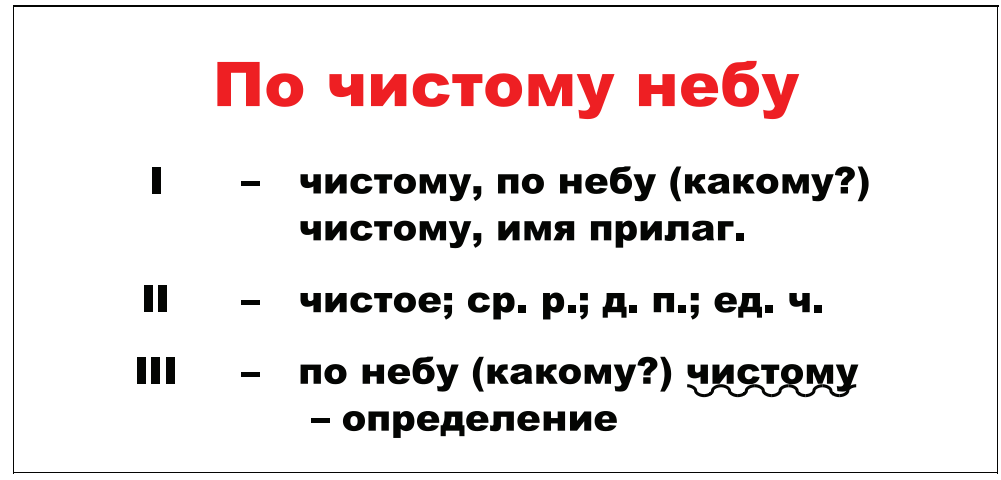

Рис. 29. Морфологический разбор прилагательного чистый

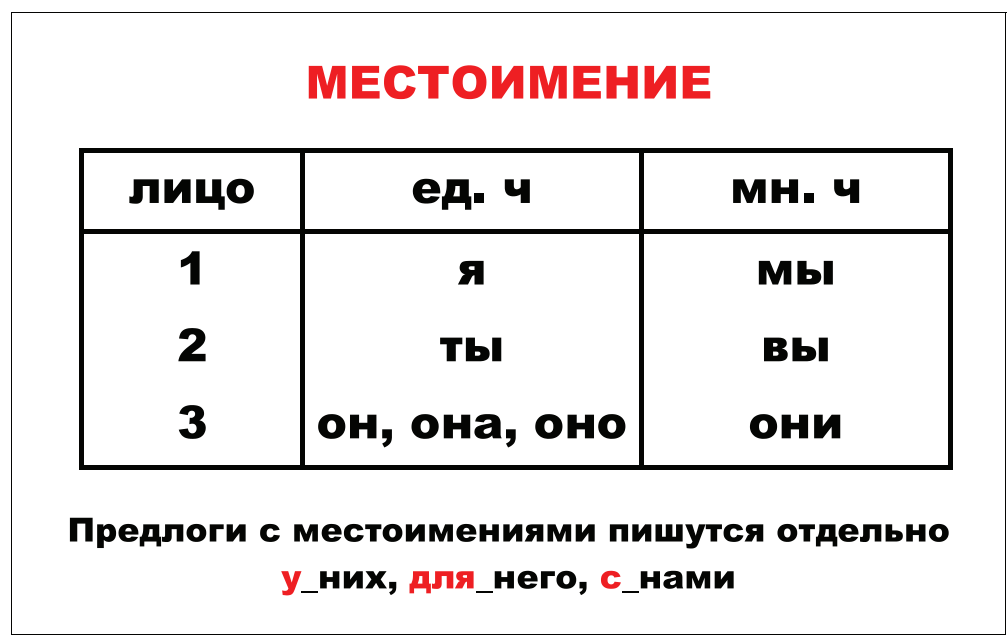

Рис. 30. Правило написания местоимения с предлогами 
Подготовка к работе по опорной таблице «Правило написания местоимения с предлогами» (рис. 30) проходит в форме беседы:

- Прочитайте предложения, написанные на доске. (Мы сажаем деревья в разрыхленную землю. Они вырастут и порадуют людей. Вы гордитесь своим трудом).

- Найдите в этих предложениях подлежащее. (Мы, они, вы).

- Называют ли в этих предложениях конкретно тех, кто сажает деревья, что вырастет, кого порадуют, кто должен гордиться? Может быть, деревья сажали школьники? А может быть, взрослые люди?

Учитель объясняет новый материала: «Слова мы, они, вы указывают на предметы, но не называют их конкретно. Такие слова называются местоимениями или личными местоимениями, так как есть еще другие виды местоимений, но об этом вы узнаете в старших классах. В предложении местоимения чаще всего бывают подлежащими, но могут быть и другими членами предложений. На какие предметы указывают местоимения, мы можем узнать из речевой ситуации».

Учитель показывает на себя и спрашивает: «Как я могу указать на себя, не называя себя? (Я)».

К доске вызываются двое обучающихся, и учитель спрашивает: «А как теперь мы укажем на нас троих, не называя себя? (Мы)».

Учитель обобщает: «Я и мы - это местоимения 1-го лица».

Аналогично проводится работа с местоимениями 2-го и 3-го лица.

После этого демонстрируется опорная таблица (рис. 30), обучающиеся изучают ее и убеждаются, что местоимения бывают 1-го, 2-го и 3-го лица, ед. ч. и мн. ч.

Учитель предлагает детям попробовать изменить местоимения по падежам, объясняя, что начальная форма для всех местоимений - местоимение в и. п. ед. ч.

Затем весь класс записывает в тетрадях предложение: «К нему тихо подошли мальчики» - и под руководством учителя проводит следующий разбор:

- Найдите словосочетания в этом предложении:
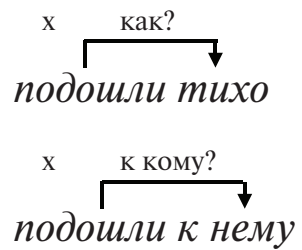

- Кто подразумевается под словами к нему? (к мужчине, к Ивану и т. д.). Конкретно не указывается, к кому подошли мальчики. Следовательно, нему - это местоимение. 
- С чем употребляется местоимение в этом предложении? (С предлогом $\kappa$ ).

- Какой вывод можно сделать? (Предлоги с местоимениями пишутся отдельно).

- Это можно проверить. Если местоимение заменить, например, существительными, то и существительные с предлогом пишутся отдельно, например: к мальчику, к Тарасу и т. д.

Для закрепления материала используются различные упражнения. Например, можно дать следующее задание: записать под диктовку учителя предложения, в которых есть местоимения с предлогами, определить начальную форму местоимения, лицо, падеж, число (если есть), каким членом предложения является местоимение.

\section{ЧТО ДЕЛАТЬ? ЧТО СДЕЛАТЬ? ДЕЙСТВИЕ глагол}

Рис. 31. Определение глагола

Сначала в процессе объяснения материала опорная таблица (рис. 31) закрыта, учитель показывает картинки с изображением предметов, их действий и состояний (например: мальчик бежит, собака плывет, шкаф стоит, цветок растет и т. п.) и проводит следующую беседу:

- Что или кто изображены на картинках? (Предметы).

- На какие вопросы они отвечают и какими частями речи являются? (Кто? Что? Имена существительные, обозначают предметы).

- Назовите действия или состояния этих предметов (бежит, плывет и т. д.).

- Подберите к этим словам вопросы. (Бежит - что делает? Плывет - что делает? И т. д.).

- На какие вопросы отвечают слова, обозначающие действия или состояния? (Учитель добавляет, что слова могут отвечать на вопросы: что делал? что сделал? что сделает? что делать? что сделать? в каком состоянии находится?). 
- Действия и состояния предмета обозначаются глаголом. (Учитель открывает опорную таблицу «Определение глагола»). Глагол - это сложная часть речи. Вы узнаете о нем много интересного в старших классах. Глагол очень богатая формами часть речи, существует очень много глаголов с приставками (например: бежал, сбежал, побежал, перебежал, убежал, прибежал), очень много глаголов с многозначностью (например: что делали? шли люди, часы, времена и т. д.).

В процессе закрепления материала проводятся различные игры и упражнения.

Упражнение «Подбери глаголы»

Учитель показывает предмет, а обучающиеся посредством вопроса подбирают к нему действия и состояния и записывают глаголы в тетради, например: человек (что делает?) спит, стол (что делает?) стоит, девочка (что делает?) поёт и т. д.

Игра «Узнай предмет по его действию»

Учитель даёт описание действия какого-то персонажа или объекта сказки, пословицы или др., а ученики должны узнать этот персонаж или объект и записать его вместе со связанным глаголом, например:

- Кто выгнал лису из лубяной избушки зайца? (Петух выгнал).

- Некоторые ждут, когда он на горе свистнет. (Рак свистнет).

- Сделав его можно смело гулять. (Дело сделать).

- Бывает, что он льет как из ведра. (Дождь льет).

Учитель в итоге обращает внимание обучающихся на то, что глаголы в предложении являются сказуемыми, и упоминает, что в старших классах они узнают, что глагол может быть любым членом предложения.

\section{НЕ с глаголом пиши ОТДЕЛЬНО!}

НЕ _ ПРИШЕЛ

НЕ _ ВЫУЧИЛ

HE _ 3HAЛ

Рис. 32. Правило написания глаголов с частицей не 
Перед объяснением нового материала учитель проводит подготовительную беседу:

- Прочитайте слова на доске (учил, узнал, вышел, поел, построил, подписал).

- Что объединяет эти слова? (Эти слова с приставками. Все слова являются глаголами).

- Как вы узнали, что это глаголы? (Они обозначают действие предмета. Они отвечают на вопрос «Что сделал?»).

Затем учитель переходит к объяснению нового, обращает внимание обучающихся на таблицу «Правило написания глаголов с частицей не» (рис. 32) и задаёт следующие вопросы:

- Являются ли слова, которые вы видите в таблице, глаголами? Почему?

- Чем отличаются глаголы, написанные на доске, от глаголов в таблице? (В таблице глаголы с частицей не).

- Как написаны глаголы с не? (Отдельно).

- Какой вывод можно сформулировать? (Не с глаголами пиши отдельно).

В процессе закрепления материала учитель использует игры и упражнения.

Упражнение «Приведи пример глагола с частицей -не»

Приведите примеры предложения, в которых есть глаголы с частицей не из прочитанных произведений по литературному чтению. Назовите автора произведения.

Игра «Закончи пословииу»

Педагог читает начало пословицы, в которых есть глаголы с частицей -не. Дети должны закончить эту пословицу и выписать из нее только глаголы с частицей не.

Солнце врагу еㅡ погасить,... (а нас не победить).

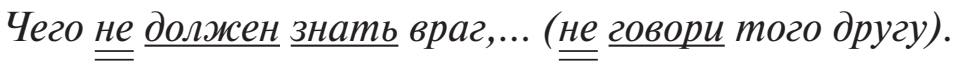

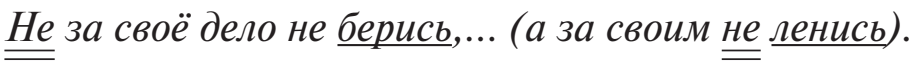

Кто за все берётся,... (тому ничего не удаётся).

При необходимости учитель оказывает помощь в завершении пословицы.

Упражнение «Письмо предложений с комментированием»

Кто любит трудиться, тому без дела не сидится.

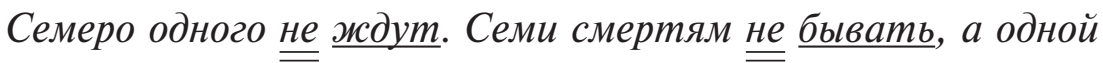
$\underline{\underline{\text { не }}} \underline{\text { миновать }}$. 
Работа по закреплению материла проводиться и по упражнениям учебника.

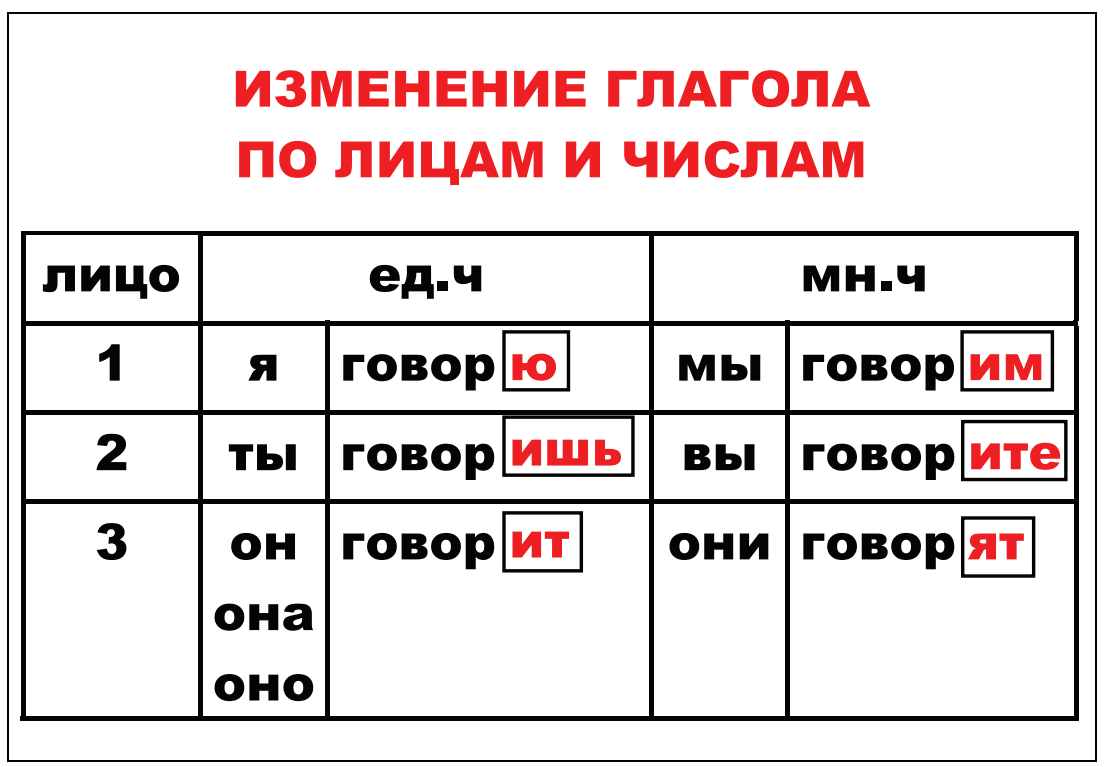

Рис. 33. Правило изменения глагола по лицам и числам

Сначала учитель проводит подготовительную работу к использованию опорной таблицы «Правило изменения глагола по лицам и числам»:

- Я, мы, они. Как мы называем одним словом эти слова (местоимения)?

- Что обозначает местоимение? (Местоимение, не называя предмета, указывает на него).

- Назовите местоимение 1-го лица (2 лица, 3-го лица).

- Назовите личные местоимения только в ед. ч. по лицам (я, ты, он, она); только во мн. ч. (мы, вы, они).

- Какое лицо личных местоимений изменяется по родам в зависимости от связанных с ним слов? (Местоимения 3-го лица, ед.ч. - он, она, оно).

- Давайте попробуем употребить глаголы настоящего времени с местоимениями 1-го, 2-го и 3-го лица:

Я кричу. Мы кричим.

Ты кричищь. Вы кричите.

Он (она, оно) кричит. Они кричат. 
- Какой вывод можно сформулировать в результате наблюдения за этими изменениями? (Глаголы изменяются по лицам).

После этого обучающимся демонстрируется таблица (рис. 33), изучение нового производится в следующей последовательности:

- Глагол какого времени мы изменяли по лицам?

- Назовите окончания глаголов 1-го, 2-го и 3-го лица настоящего времени, ориентируясь на таблицу. Ударные они или безударные?

- Измените по лицам глагол написать. Какие окончания у глагола в 1-м, 2-м и 3-м лице? Ударные они или безударные (безударные)?

- Попробуйте изменить по лицам глагол написать в прошедшем времени. Что интересного вы заметили? (По лицам глагол в прошедшем времени не изменяется, а в 3-м лице изменяется по родам: я написал, ты написал, он написал, она написала, оно написало).

В процессе закрепления материала зачитываются предложения с последующим выделением глаголов и определением их времени и числа.

\section{ВРЕМЯ ГЛАГОЛА}

НАСТОЯЩЕЕ ВPEMЯ

\section{ПРОШЕДШЕЕ} BPEMЯ

\section{БУДУЩЕЕ ВРЕМЯ}

(4то делает?) пишет, рисует, спит, думает

(что делал? что сделал?) написал, рисовал

(4то будет делать?

что сделает?)

будет писать,

напишет

Рис. 34. Время глагола 
В процессе подготовительной работы опорная таблица «Время глагола» (рис. 34) закрыта. Учитель просит прочитать предложение, написанное на доске, найти в нем словосочетание с глаголом и поставить к нему вопрос от связанного слова: «Комар летает над водой».

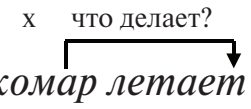

Учитель спрашивает обучающихся: «Когда выполняется действие предмета (комар) в этом словосочетании? (В настоящий момент). Следовательно, глагол летает мы можем назвать глаголом настоящего времени».

Предлагается следующее предложение: «Журавль улетел в теплые края». Работа по определению времени глагола проводится аналогично предыдущему этапу.

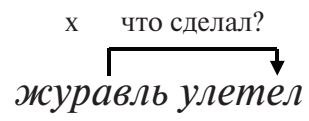

Учитель ставит следующий вопрос: «Когда выполняется действие предмета (журавль) в этом словосочетании? (Действие уже совершилось в прошлом). Как мы можем назвать глагол улетел? Мы можем назвать его глаголом прошедшего времени».

Учащимся предлагается предложение: «В сентябре Миша пойдёт в школу».

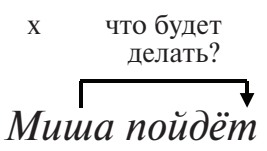

Учитель спрашивает обучающихся: «Когда выполняется действие предмета (Миша) в этом словосочетании? (Действие еще не совершено, оно произойдет в будущем). Как мы можем назвать глагол пойдёт? Мы можем назвать его глаголом будущего времени».

После такого разбора демонстрируется таблица (рис. 34). Объяснение материала проходит в следующей последовательности:

- Перед вами таблица, в которой в краткой форме сделаны выводы по проведенной нами работе. Составьте рассказ о временах глагола по таблице. (Поочередно отвечают два ученика).

- В каком числе даны глаголы в таблице? Поставьте их во мн.ч.

В процессе закрепления изученного проводится запись предложений с полным комментированием всех известных орфограмм. После записи предложений обучающиеся определяют их время и число. 


\section{Примерный текст}

В пруду вода замерзает. Хвостатый тритон давно ушел из пруда в лес. Лягушки ныряют, забиваются в ил. Змеи уже зарылись под корни, в мох. Скоро зима скуёт землю и воду льдом. Куда тогда денешься?

Закрепление и обобщение материала по данной теме проводится и с помощью упражнений в учебнике.

\section{НЕОПРЕДЕЛЕННАЯ ФОРМА ГЛАГОЛА \\ (инфонитив)}

\section{ЧТО ДЕЛАТЬ?}

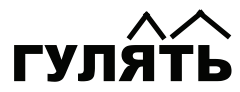

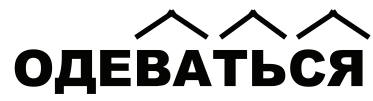

SEPEUb
ЧТО СДЕЛАТЬ?

услышАิАิЬ

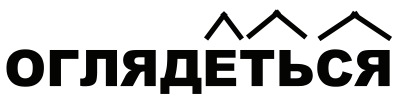

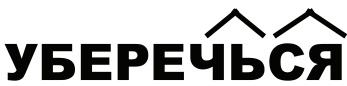

Рис. 35. Неопределенная форма глагола

На первом этапе учитель проводит подготовительную работу в виде опроса, в процессе которого обучающиеся воспроизводят ранее изученное и таким образом подводятся к изучению нового материала (при необходимости применяются использовавшиеся ранее опорные таблицы):

- Вспомните, на какие вопросы отвечают глаголы? Что они обозначают?

- Определите вид, время, число глаголов бежал, испугался, съел, ел, ест, поедут, поеду, упадёшь.

- Прочитайте глаголы (на доске записаны глаголы дышать, подышать, встречать, беречь). Определите их лицо, время и число. Смогли вы это сделать (нет)? Такие глаголы называют глаголами неопределенной формы, или инфинитивом. 
Учитель демонстрирует опорную таблицу «Неопределенная форма глагола» (рис. 35) и объясняет новый материал в следующей последовательности:

- Посмотрите на опорную таблицу. На какие вопросы отвечают глаголы неопределенной формы? (Что делать? Что сделать?).

- Как могут оканчиваться глаголы неопределенной формы (на -mb, $m ь c я,-ч b, ~ ч ь c я)$ ? Мягкий знак пишется и у инфинитива, и у вопроса, поставленного к нему.

- Образуйте от глагола неопределенной формы глаголы настоящего, прошедшего и будущего времени (писать - пишу - писал - напишу).

- Следовательно, от основ инфинитива образуются все другие формы глаголов. Поэтому инфинитив считают начальной формой глагола.

Учитель также обращает внимание обучающихся на то, что суффиксы инфинитива могут быть ударными и безударными. Предлагается самим привести примеры глаголов неопределенной формы, определить ударные и безударные суффиксы этих глаголов.

Обращается также внимание на то, что глаголы-инфинитивы пишутся с мягким знаком (что делать? что сделать?), а глаголы настоящего времени без мягкого знака (что делает? что делают?)

Закрепление изученного проводится с опорой на таблицу (рис. 35). Например, учитель предлагает обучающимся назвать инфинитивы из прочитанных на уроках литературного чтения произведений, а затем записать их с комментированием.

\section{СПРЯЖЕНИЕ ГЛАГОЛОВ}

II спряжение

\section{I спряжение}

\section{ИTb+}

гнать, держать, терпеть, обидеть, слышать, видеть, ненавидеть, зависеть, вертеть, дышать, смотреть

$$
\begin{array}{c|c}
\text { - } и & -\mathrm{e} \\
\text { - ат (-ят) } & \text { - ут (- ют) }
\end{array}
$$

Рис. 36. Правило спряжения глаголов 
Перед объяснением материала по таблице «Правило спряжения глаголов» (рис. 36) учитель проводит подготовительную беседу:

- Вспомните, что называют спряжением глаголов. (Спряжение - это изменение глаголов по лицам).

- Какие глаголы изменяются по лицам? (По лицам изменяются глаголы настоящего и будущего времени).

Проспрягайте глаголы идти и спешить.

$$
\begin{array}{ll}
1 \text { л. иду -идём } & 1 \text { л. спешу - спешим } \\
2 \text { л. идешь -идёте } & 2 \text { л. спешишь - спешите } \\
3 \text { л. идёт - -идут } & 3 \text { л. спешит - спешат }
\end{array}
$$

- Чем различаются глаголы этих двух спряжений? (Они различаются окончаниями. У первого глагола в окончаниях пишется буква $-e(\ddot{e})$ : -ем, -ешь, -ёте, -e, а в третьем лице множественного числа - -ym(ют). У второго глагола в окончаниях пишется буква $u$ : -uм, -ишь, -ume, -um, а в третьем лице множественного числа - -am (-яm)).

Учитель объясняет правило, отображенное на таблице «Правило спряжения глаголов» следующим образом: «Глаголы I спряжения имеют в окончании букву $-u$, а II - букву $-e$. Если окончание ударное, то различение глаголов I и II спряжения не представляет трудности: пищúm - ясно слышим -u, поёm - ясно слышим -ё. Но если окончания безударные, то можно ошибиться. Как правильно написать окончания в глаголах гони́шь, стреко́чет? Для этого надо узнать, какого они спряжения. Спряжение можно определить по неопределенной форме глагола. Для этого надо обязательно запомнить следующее правило: ко II спряжению относятся:

- все глаголы с безударными окончаниями, если их неопределенная форма оканчивается на -ить;

- 7 глаголов-исключений на -еть;

- 4 глагола на -ать (учитель вместе с обучающимися читает их на таблице и пробует проспрягать в настоящем и будущем времени).

Все остальные глаголы с безударными личными окончаниями относятся к I спряжению. Бывают разноспрягаемые глаголы. Вы узнаете о них в старших классах».

После объяснения материала можно предложить детям выучить стихотворение о спряжении глаголов для лучшего запоминания правила.

Работа по закреплению материала проводится с опорой на таблицу.

Упражнение «Письмо с полным комментированием»

Сначала учитель даёт образец письма с комментированием на 1-2 примерах.

Гого́чет - в окончании то ли -ет, то ли -um. В неопределенной форме глагол гоготать - оканчивается на $-a m b$, не является исключением, значит, это глагол I спряжения. Пишу окончание -em. 
Кра́сишь - окончание безударное, то ли -ешь, то ли -ишь. В неопределенной форме глагол красumb - оканчивается на -umb, значит, это глагол II спряжения. Пишу окончание -uшь.

Учитель поочередно просит обучающихся на основе его образца прокомментировать написание предложенных глаголов.

Упражнение «Поверочное письмо»

Записывается текст под диктовку, а затем ребята объясняют правописание окончаний глаголов.

В качестве текста для письма могут быть предложены пословицы о дружбе:

Дружбу за деньги не ку́nищь.

Когда друг просит, не существует завтра.

Крепкую дружбу и топором не разруббши.

Над другом посмёшься - над собой попла́чешь.

Закрепление материала также достигается работой с упражнениями учебника.

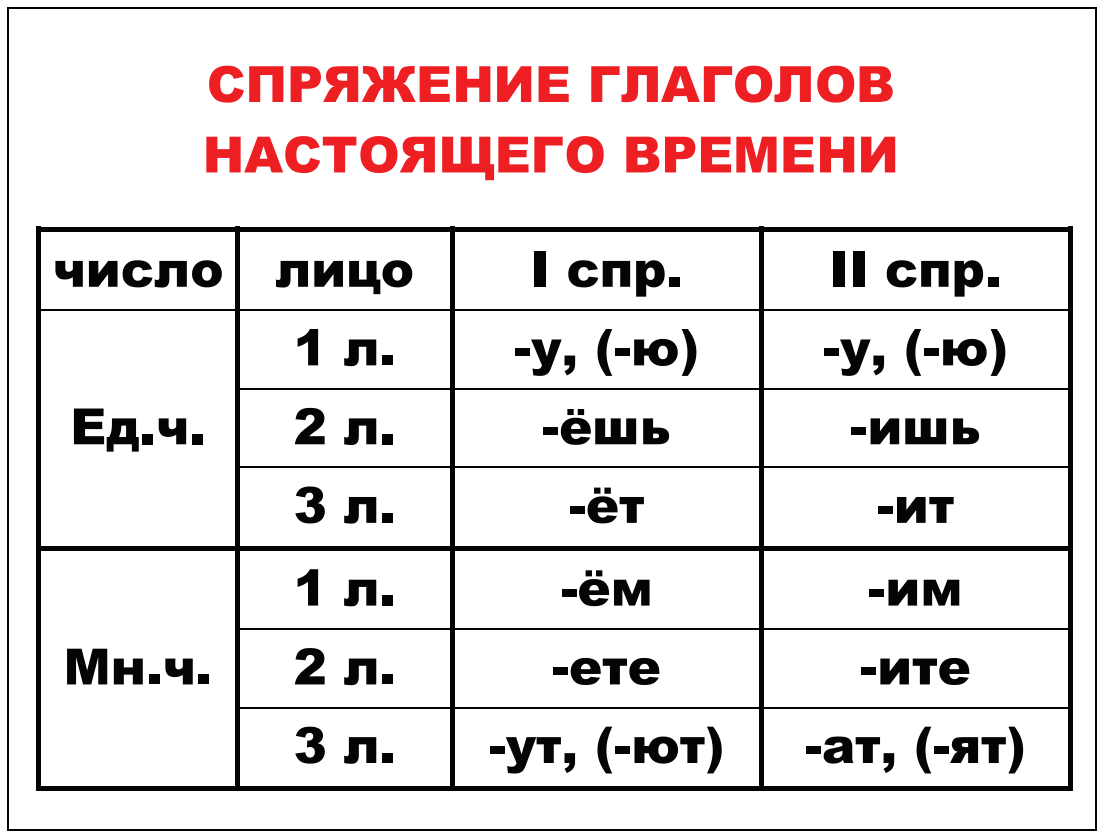

Рис. 37. Правило изменения глагола по лицам и числам

В процессе подготовительной работы к использованию опорной таблицы «Правило изменения глагола по лицам и числам» (рис. 37), два ученика 
работают поочередно у доски, а остальные обучающиеся в тетрадях спрягают глаголы идти, мешать, а затем глаголы учить, говорить в единственном и множественном числе. В результате на доске появляется две записи с вынесенными на поля окончаниями.

Запись с глаголами идти, мешать

Ед. ч.

1-е л. Я иду́, меша́ю.

$-y,-ю$

2-ел. Ты идёшь, меша́ешь.

-ёшь, -ешь

3-е л. Он (она, оно) идёт, меша́ет.

-ёm, -em

Мн. ч.

1-ел. Мы идём, мешаемм.

$-\ddot{e} M,-e M$

2-е л. Вы идёте, меша́ете.

-ёme, -eme

3-е л. Они иду́m, меша́ют.

$-y \dot{m},-ю m$

Запись с глаголами учить, говорить

Ед. ч.

1-е л. Я уччу, говорю́.

$-y,-ю$

2-ел. Ты уччишь, говориішь.

$-и ш ь,-и ш ь$

3-ел. Он (она, оно) у'чит, говорит.

$-u m,-u m$

Мн. ч.

1-ел. Мы у'чим, говори́м.

$-u м,-u м$

2-ел. Вы учите, говориіте.

-ume, -ume

3-ел. Они у́чат, говоря́т.

$-a m,-я m$

Учитель проводит следующую беседу с обучающимися по этим записям:

- Посмотрите на первую работу. Какие окончания у глаголов настоящего времени? (Обращается внимание на одинаковое написание ударных и безударных окончаний глаголов).

- Посмотрите на окончания глаголов во второй работе. (Обращается внимание на одинаковое написание ударных и безударных окончаний каждого лица).

- Чем отличаются окончания глаголов настоящего времени в первой работе от написания окончаний во второй работе? Сделайте выводы.

Обучающиеся должны прийти к выводам, что:

1) в окончаниях глаголов в первой работе пишутся буквы $\ddot{e}, e$ (-ёшь, -ешь, -ёт, -ет, -ём, -ем, -ёте, -ете), у и ю (-ут, -ют);

2) в окончаниях глаголов во второй работе пишутся буквы $u$ (-ишь, -ишь, -ит, -ит, им, -им, -ите, -ите), а и я (-ат, -ят). 
Учитель дополняет, что окончания, которые они увидели в первой работе, - это окончания глаголов I спряжения, а во второй работе, - окончания II спряжения. Дети открывают учебник и читают правило по новой теме, после чего им демонстрируется опорная таблица (рис. 34), на основе которой объясняют написанный в таблице текст о спряжениях глаголов.

Далее учитель предлагает глаголы неопределенной формы, а обучающиеся с опорой на таблицу спрягают их в настоящем времени. На основе этой таблицы учитель может продемонстрировать, что таким же образом спрягаются глаголы будущего времени с приставками, а глаголы прошедшего времени - не спрягаются.

В качестве средства закрепления материала учитель предлагает разнообразные упражнения, например, просит записать предложения, найти глаголы, определить их лицо, число, спряжение и др.

\section{МОРФОЛОГИЧЕСКИЙ РАЗБОР ГЛАгОЛОв}

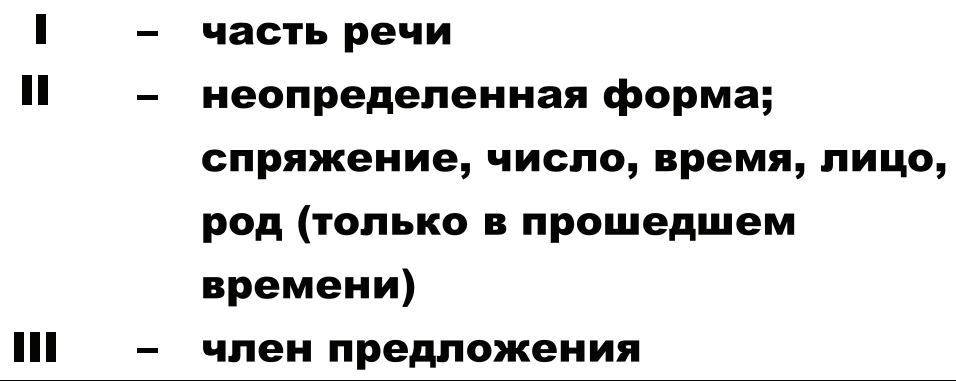

Рис. 38. Морфологический разбор глагола

Перед объяснением последовательности морфологического разбора глагола, учитель предлагает обучающимся вспомнить, слова каких частей речи они ранее подвергали морфологическому разбору (при необходимости используются соответствующие таблицы по морфологическому разбору существительных и прилагательных):

- Как разбирали существительное? Прилагательное?

- Посмотрите на опорную таблицу с планом морфологического разбора глагола (рис. 38). Чем план разбора глагола отличается от плана разбора существительного? 
В качестве примера морфологического разбора глагола также может быть продемонстрирована таблица «Морфологический разбор глагола светит» (рис. 39).

\section{Светит солнце.}

I - светит, солнце (что делает?) светит, обозначает действие, глагол

II - светить; несов. вид.; II спр.;

В ед. Ч., В наст. вр., В 3 лице

II - солнце (4то делает?) светит

- сказуемое

Рис. 39. Морфологический разбор глагола светит

В качестве средства закрепления материала используются игры и упражнения.

Игра «Кто лучше?»

Три ученика у доски соревнуются в устном морфологическом разборе глаголов из продиктованных учителем предложений:

1. Сенокос идёт в июле.

2. В лесу птицы построили себе гнездо.

3. Поздней осенью звери спрячутся в своих жилищах.

Самостоятельная работа

Используя опорную таблицу (рис. 38), обучающиеся выполняют в тетрадях морфологический разбор глаголов из предложений, предложенных учителем (работа по вариантам). 


\section{ПРЕДЛОГИ ПИШИ} ОТДЕЛЬНО!
$\mathbf{K}$
B
$3 \mathbf{a}$
IOA
ה
перед
Ha
c npo
около
BOKPуг
no
y
o
06
над между

\section{Лодка отплыла от берега.}
Лодка отплыла от (чего?) берега. Лодка отплыла от (крутого) берега.

\section{Рис. 40. Правило написания предлогов}

При объяснении правила написания предлогов со словами учитель обращает внимание обучающихся на таблицу (рис. 40) и говорит: «Прочитайте первое предложение. Найдите слово с приставкой (отплыла). Подберите однокоренные слова к слову отплыла (плыла, приплыла, уплыла). Какие лексические значения добавляют к слову плыла приставки -om, -npu, $-y$ ? Попробуйте вставить между приставкой и корнем новое слово. (От реки плыла). Можно ли так говорить (нет)? Прочитайте словосочетание в первом предложении таблицы (отплыла от берега). Как связаны друг с другом слова отплыла и берега? (Они связаны с помощью предлога om). Что можно вставить между предлогом и связанным словом? (Вопрос или другое слово). Какой вывод можно сделать? (Приставка - это часть слова. Её не отделяют от корня слова. А предлог - это отдельное слово, поэтому пишем его раздельно с другими словами в предложении. Между предлогом и словом всегда можно поставить вопрос или другое слово)».

После проведенной работы дети читают предлоги в верхней части таблицы и составляют словосочетания с этими предлогами.

Закрепление материала может проводиться с помощью разнообразных игр и упражнений. Приведем примеры.

Игра «Кто больше?»

Учитель делит класс на команды, например по следующим основаниям: «первый ряд - второй ряд» или «девочки - мальчики» и даёт командам различные словосочетания с заданием определить, где в нем использована приставка, а где предлог. За каждое правильное объяснение команде начисляются баллы. 
Примеры заданий и их выполнения:

1) подойти к столу (подойти к большому столу, значит, это предлог, он пишется отдельно);

2) подойти к столу (нельзя вставить слово между под- и остальной частью слова, значит, это приставка, а не предлог; пишем слитно);

3) прибежал к дереву (подбежал к огромному дереву - можно вставить слово, значит, это предлог; он пишется отдельно);

4) прибежал к дереву (нельзя вставить слово между при- и остальной частью слова, значит, это приставка, а не предлог; пишем слитно).

Упражнение «Письмо с комментированием»

Обучающимся диктуются предложения на усвоение изучаемого правила, один из учеников вслух комментирует ход выполнения упражнения.

Примеры предложений:

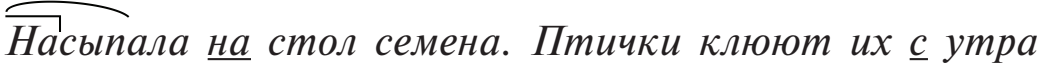
в морозы.

На следующих уроках проводится повторение пройденного и обобщение материала. Обучающиеся могут пользоваться таблицей при выполнении других заданий учителя и упражнений по учебнику.

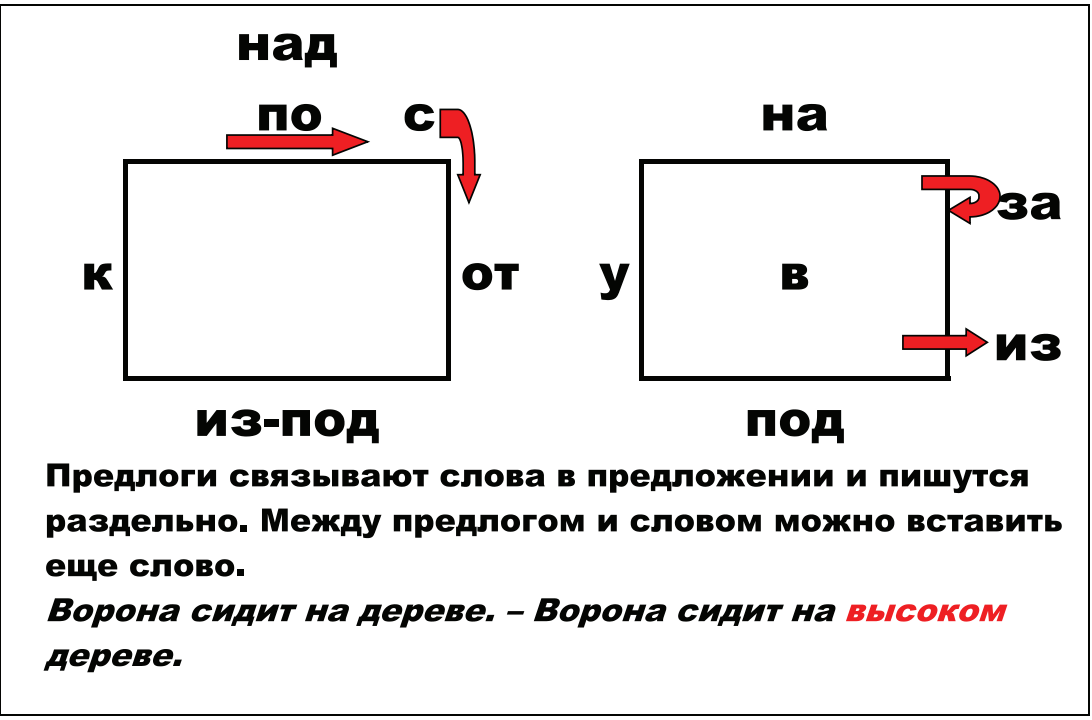

Рис. 41. Правило использования предлогов 
Таблица «Правило использования предлогов» (рис. 41) используется как продолжение работы по предыдущей таблице (рис. 40). Прежде чем демонстрировать обучающимся таблицу, учитель проводит опрос:

- Вспомните, что вы уже знаете о предлогах? (Предлог - это отдельное слово. Предлоги связывают слова в предложении. Предлоги пишутся отдельно от связанного с ним слова. Между предлогом и словом можно вставить еще слово).

- Придумайте словосочетания, в которых предлоги связывают слова.

После опроса учитель открывает таблицу и говорит: «Представьте, что эти прямоугольники - столы. Составьте словосочетания, используя этот рисунок. Используйте вопросы при составлении словосочетаний».

Далее учитель даёт слова, опираясь на которые обучающиеся с помощью опорной таблицы составляют словосочетания:

\begin{tabular}{|l|l|}
\hline \multicolumn{1}{|c|}{ Учитель } & \multicolumn{1}{c|}{ Обучающиеся } \\
\hline висит & над (чем?) $\longrightarrow$ над столом \\
катается & по (чему?) $\longrightarrow$ по столу \\
упал & с (чего?) $\longrightarrow$ со стола \\
отошел & от (чего?) $\longrightarrow$ от стола \\
достал & (откуда?) $\longrightarrow$ из-под стола \\
\hline
\end{tabular}

Обращается внимание на то, что написание предлогов не зависит от их произношения, что они пишутся всегда одинаково.

Закрепление материала проводится посредством различных упражнений. Дадим их описание.

Упражнение «Объяснительное письмо»

Обучающиеся читают текст, находят слова с приставками и предлоги со связанными словами, объясняют их правописание, а затем пишут текст в тетрадях под диктовку учителя.

Выпал в городе первый снег. Побелели крыши домов и улииы. Мороз нарисовал на окнах узоры. Тишина стоит над землей.

\section{Упражнение «Выборочное письмо»}

Учитель читает предложения, а обучающиеся в первый столбец записывают слова с приставками, а во второй - предлоги и связанные с ними слова.

Весь лес свверху донизу занят под жильё. Живут на земле,

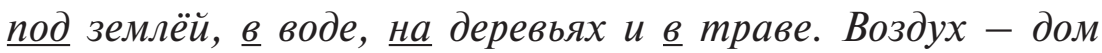
иволги. Она высоко над землей подвесила гнездо к ветке

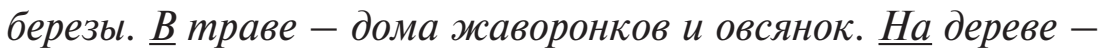

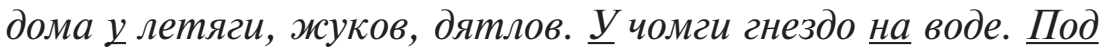
водой выстроил домик водяной паук. 


\section{3. Таблицы для изучения раздела «Состав слова»}

\section{ОДНОКОРЕННЫЕ \\ ФОРМЫ \\ СЛОВА \\ СЛОВА}
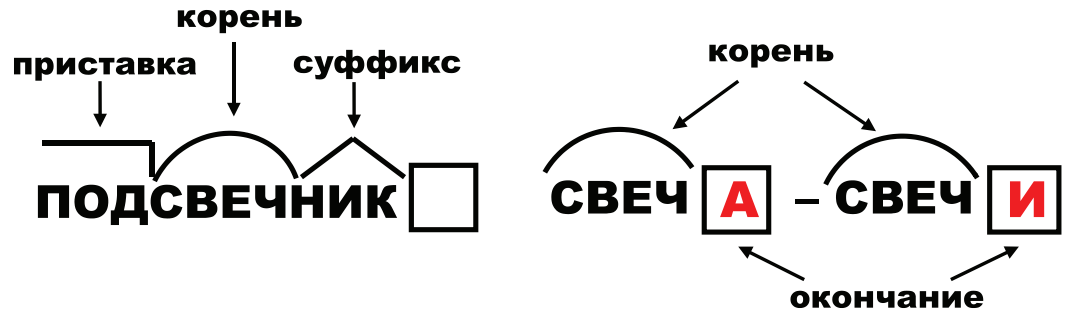

Рис. 42. Правила словообразования и словоизменения

Перед демонстрацией опорной таблицы «Правила словообразования и словоизменения» (рис. 42) учитель проводит подготовительную работу в виде беседы:

- Вода, водичка, подводный. Что общего в этих словах? (У них общая часть - корень).

- Что еще у них есть общего? (Они близки по значению).

- Докажите, что они близки по значению. (Вода - это прозрачная жидкость; водичка - ласкательное значение слова вода; подводный - отражает отношение других предметов к воде, например, камень под водой).

- Как мы называем такие слова? (Родственными или однокоренными).

- Следовательно, какие два условия необходимы для подбора однокоренных слов? (Общий корень и близость по значению).

- Какая часть перед корнем образует слова с новым значением? (Приставка). Докажите. (Учащиеся приводят примеры).

- Какая часть слова после корня образует слова с новым значением? (Суффикс). Докажите.

- Образуют ли окончания слова с новым значением? (Нет, они могут образовывать формы ед. ч., мн. ч., помогают связи слов в словосочетаниях, предложениях). Докажите. (Нахожусь у школьы. Встретились в школе). Сделайте вывод об окончании. (Окончания образуют формы слов при их связи).

После проведенной беседы учитель демонстрирует опорную таблицу (рис. 42) и объясняет материал по теме. 
Обучающиеся изучают содержание таблицы, устно составляют предложения со словами, отраженными в таблице.

В процессе закрепления материала проводятся различные игры и упражнения.

Упражнение «Подбор однокоренных слов по схеме»

Учитель предлагает схемы с составом слова, а дети подбирают к ним подходящие слова и комментируют свой выбор.

Примеры схем:

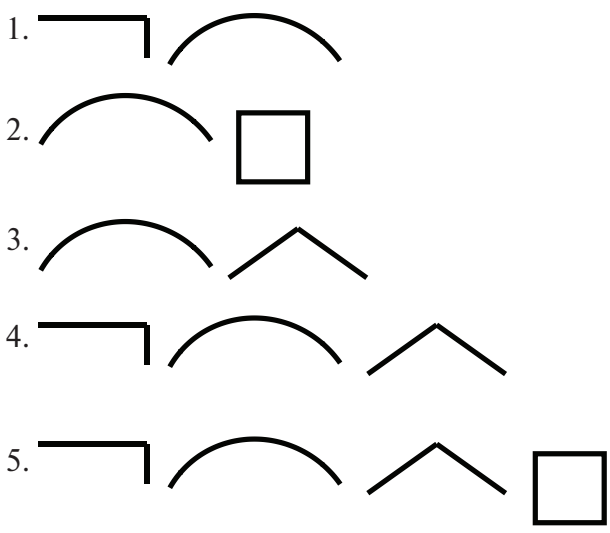

При необходимости учитель оказывает помощь, например, предлагает к схеме корень слова (бег), а детм остается подобрать приставку (побег) или другие части слова.

Игра «Не ошибайся»

Учитель называет пары слов, а обучающиеся должны сказать, были названы однокоренные слова или формы слова, и обосновать свой ответ.

Примеры слов:

1) ход, уходит (однокоренные слова);

2) рыба, рыбы (формы слов);

3) бег, забег (однокоренные слова);

4) стол, на столе (формы слов);

5) школы, школьник (однокоренные слова);

6) дым, дымок (однокоренные слова);

7) диван, диваном (формы слов);

8) груз, грузовик (однокоренные слова); 


\section{COCTAB CJOBA}

\section{KOPEHb ПРИСТАВКА СУФФИКС

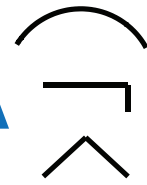 \\ cлужат пля образования новbх слов

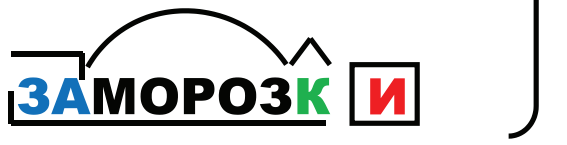
ОКОНЧАНИЕ $\square$ СТОЛ НА СТОЛ E
изменяемая часть слова (служит для Свази слов в предлокении)

Рис. 43. Состав слова

Перед ознакомлением обучающихся с таблицей «Состав слова» (рис. 43) подготовительная работа проводится в следующей последовательности:

- Запишите в тетрадях слова дом - домик. Какая часть слова у них общая? (дом).

- Выделите корень дугой. (Учитель показывает на доске, как выделять корень). Это значимая главная часть слова.

- Какое лексическое значение у слова дом? (Жилое задание или любое учреждение).

- Какое значение добавляет часть -ик к слову дом? (Он добавляет уменьшительно-ласкательное значение). Где находится часть -ик? (После корня).

- Выделим эту часть углом сверху и назовём суффиксом. (Учитель показывает на доске).

- Запишите слова город - пригород. Почему их можно назвать однокоренными?

- Какая часть добавляет слову новое значение и где она стоит? (Часть -nри, она стоит после корня). Выделим приставку прямым углом. (Демонстрируется на доске).

- Запишите слова гора - горы. Почему их нельзя назвать однокоренными? 
- Какая часть слова образует форму мн. ч.? (-ы). Эту часть слова назвали окончанием. Окончания помогают связать слова в предложении. Окончание выделяется прямоугольником. (Демонстрируется на доске).

- Какие формы есть еще у слова гора? (горой, гору, о горе и др.).

После поведенной беседы открывается таблица (рис. 43), и обучающиеся с опорой повторяют новый материал.

Для закрепления материала проводятся игры и упражнения с использованием опорной таблицы.

Упражнение на образование существительных суффиксальным и префиксальным способом»

Учитель предлагает слова, а обучающиеся образуют из них сначала новые слова с помощью суффиксов, а затем - с помощью приставок.

$\begin{array}{ll}\text { Учитель: } & \text { бег } \\ \text { Учашиеся: } & \text { бегун } \\ & \text { бегство } \\ & \text { побег } \\ & \text { разбег } \\ & \text { забег }\end{array}$

Игра «Кто быстрее?»

Учитель называет словосочетание из двух слов, первое из которых отвечает на вопрос «Что сделал?», а дети должны как можно быстрее заменить словосочетание одним словом с тем же значением и с приставкой:

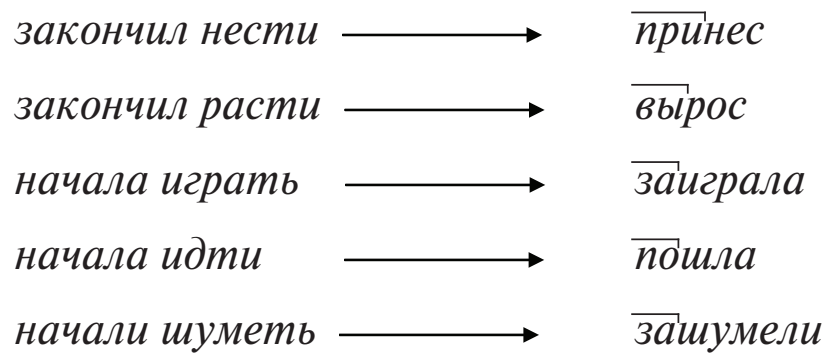




\section{Игра «Кто последний - тот победитель»}

Обучающиеся образуют из заданного корня (например, снег) слова суффиксальным и префиксальным способом и записывают их в тетрадях. После завершения работы слова́ поочередно зачитываются обучающимися. Тот, кто закончил последним, т. е. образовал больше всех слов, побеждает. Учитель обращает внимание на образованные сложные слова (снегоход, снегоочиститель, снегопад и др.), объясняя, что у них иной способ словообразования.

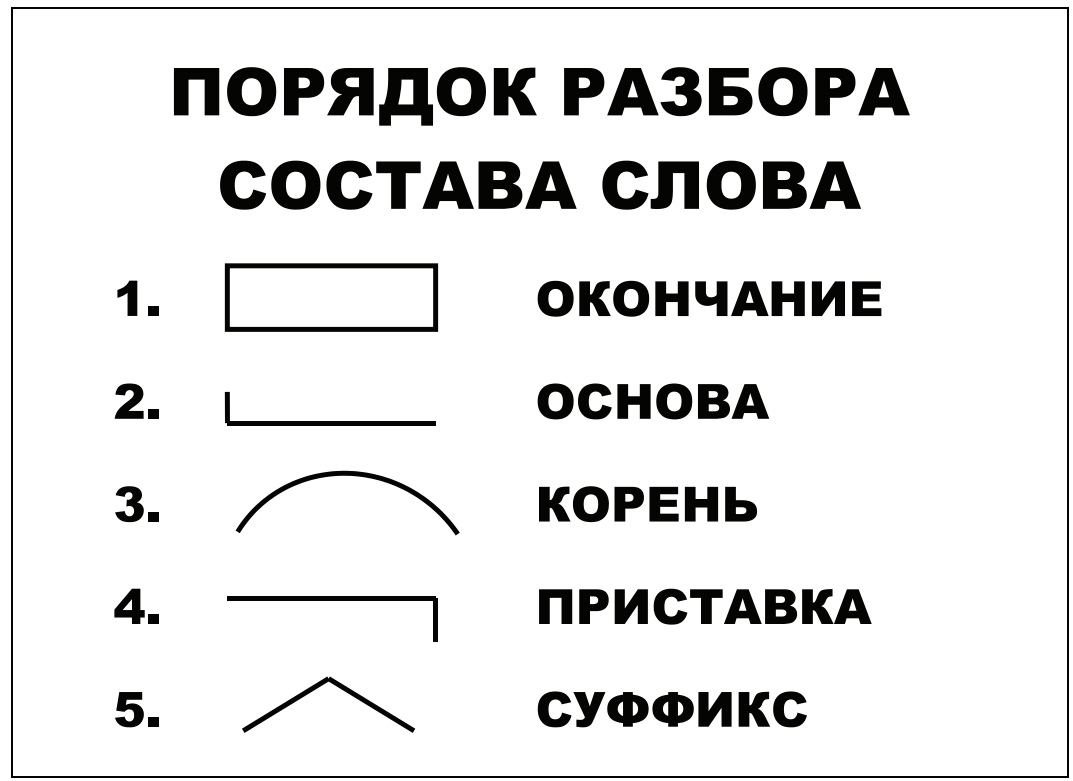

Рис. 44. Порядок разбора состава слов

Учитель проводит подготовительную работу к объяснению новой темы следующим образом:

- Из каких частей могут состоять слова? Приведите примеры.

- Что следует сделать, чтобы правильно выделить в слове корень? (Следует подобрать однокоренные слова и выделить общую часть - корень).

- Как выделить окончание? (Это изменяемая часть слова, значит, необходимо изменить слово, найдя его другие формы).

- Как найти приставку? (Она находится перед корнем и образует слова с новым значением).

- Как найти суффикс? (Он находится после корня и образует слова с новым значением). 
Учитель переходит к изучению новой темы и предлагает изучить порядок разбора слов по составу по таблице (рис. 44) и запомнить его. Обучающимся даётся образец разбора слова заморозки с комментированием всех действий: «Заморозки. Нахожу окончание. Для этого изменяю слово: заморозками, заморозков. Изменяемая часть - - , следовательно - - - это окончание, выделяю его. Часть слова без окончания - это основа, выделяю ее снизу чертой. Нахожу корень. Для этого подбираю однокоренные слова: мороз, морозеи. Общая часть - мороз. Выделяю корень мороз дугой. Часть слова $-\kappa$ после корня даёт слову новое значение - это суффикс. Выделяю его углом. Часть слова -за образует новое значение слова и находится перед корнем - это приставка. Выделяю ее прямым углом сверху».

После проведенного разбора на доске появляется следующая запись:

$$
\text { заморозк } и
$$

Для закрепления материала учитель организует самостоятельный разбор слов книжкк, поездка с опорой на таблицу и образец, данный учителем.

\section{4. Таблицы на правописание орфограмм}

\section{XK, ШИ \\ пиши с буквой И \\ (жизнь, машина...)}

Рис. 45. Правописание жи, ши

Учитель предлагает решить ребусы на угадывание слов жизнь и машина (рис. 46). До их угадывания эти слова в таблице «Правописание жжи- шu» (рис. 45) закрыты. 
Обучащимся предлагаются следующие ребусы:

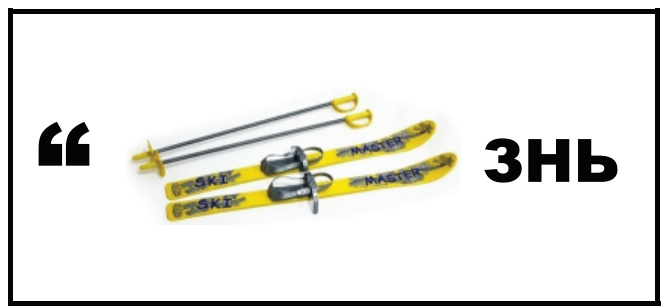

(жизнь)

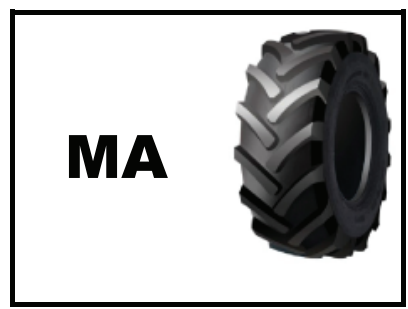

(машина)

Рис. 46. Ребусы на правописание слов с жи, ши

После разгадывания ребусов учитель проводит беседу: «Найдите в этих словах шипящие звуки ([ж], [ш]). Как они произносятся? (Твёрдо). Но после твёрдых звуков $ж, u$ не пишется буква $b$. Почему же пишется $u$ ? Когда-то очень давно звуки же и $u$ в русском языке были мягкими и после букв «ж» и «ш» писали букву «и», и до сегодняшнего дня эта традиция сохранилась. Поэтому это написание является исключением из правила». Далее обучающиеся изучают опорную таблицу (рис. 45), оформляют ее в тетради и дополняют другими словами с жи, ши.

В процессе закрепления материала можно использовать следующие задания.

1. Найдите названия предметов в классе, в которых есть жи, ши (карандащи, uпы (у розы) и т. д.)». Проводится письмо с комментированием.

2. Игра «Кто больше?»

3. Составление предложений со словами на жи, ши с проговариванием и комментированием, например: «У шиповника острые шипы», «Ученику сшили новый жилет», «У меня живёт собака Пыжик».

4. Работа над орфограммой по упражнениям учебника.

\section{ЧА, ПА}

\section{пиши с буквой А}

\section{(чайка, щавель, чаща)}

Рис. 47. Правописание ча, ща 
При объяснении правописания орфограммы ча, ща учитель для привлечения внимания учащихся даёт занимательное задание, например, ребусы (рис. 48).

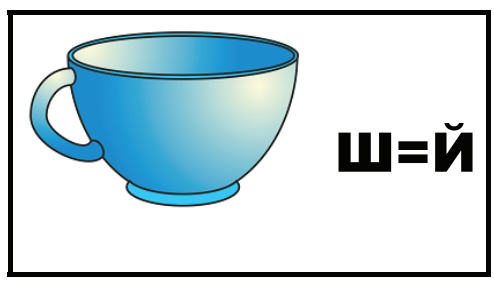

(чайка)

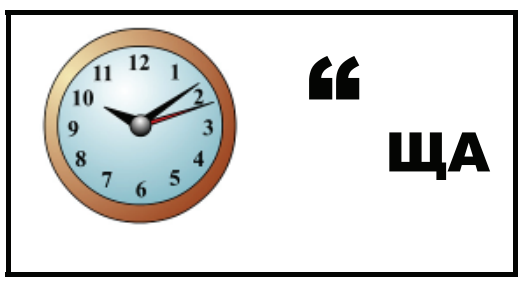

(чаща)

Рис. 48. Ребусы на ча, ща

После решения ребусов учитель задаёт вопросы:

1. Что объединяет названия угаданных предметов? (Во всех отгаданных словах есть шипящие).

2. Какие это звуки - твёрдые или мягкие? (Мягкие).

3. Какая буква пишется после шипящих? (Буква $a$ ).

4. Какими гласными буквами обычно обозначаются мягкость согласных звуков $(я, e, \ddot{e}, ю, u)$ ?

5. Буква а обозначает твёрдость звуков. В словах чайка, щавель, чаща звуки ч и $ш$ мягкие. Почему же здесь пишется гласная $a$, а не $я$ ?

Далее учитель, указывая на таблицу «Правописание ча, ща» (рис. 47), объясняет написание ча, ща как исключения в русском языке.

Материал правописания ча, ща закрепляется с опорой на таблицу посредством игр и упражнений. Дадим их описание.

\section{1. Игра «Кто больше?»}

Учитель организует соревнование. К доске выходят несколько обучающихся и на скорость записывают слова на правописание ча, ща. Остальные работают в тетрадях. Через 3 минуты учитель подводит итоги соревнования.

2. Упражнение «Запись предложений с комментированием и проговариванием»

Учитель вызывает к доске одного обучающегося, который записывает на доске предложение, и по мере записи комментирует и проговаривает его. Например: «Хоть волчата и молчат - нелегко найти волчат», «А у маленьких зайчат ушки малые торчат» и т. п.

\section{3. Зарядка}

Учитель называет слова с орфограммой ча, ща. Когда он называет слово с орфограммой ча- встают девочки, выполняют наклоны в стороны и хором проговаривают слово и орфограмму «Ча пиши с буквой $a »$. Мальчики выполняют то же упражнение на орфограмму ща. 
4. Хоровое заучивание стихотворения

Сочетания ща и ча

В словах: пища и свеча,

Куча, гуща, каланча,

Туча, роща, саранча.

Чаща, дача и печать - нужно с буквой а писать!

Далее тема с опорой на таблицу закрепляется при выполнении упражнений в учебнике.

Подобным образом с опорой на таблицы отрабатывается правописание чу, щу.

\section{ЧК, ЧН, НЧ}

\section{никогда не пишется с b (девочка, отличник, кончик...)}

Рис. 49. Правописание чк, чн

Объяснение орфограммы на правописание чк, ин, ни можно начать с загадки и дальнейшего фонетического разбора слова-отгадки (опорная таблица «Правописание чк, чн, нч» при этом закрыта): «Как называется чехол для подушки?» (Наволочка).

Затем учитель проводит беседу с обучающимися:

- Какой шипящий звук содержится в слове наволочка?

- Как мы обозначаем мягкость согласных букв? (Мягкость согласных обозначается гласными $u, я, e, \ddot{e}, ю$, а еще мягким знаком).

- В слове наволочка после $и$ стоит твёрдый согласный $\kappa$. Как вы думаете, почему после $u$ не написали мягкий знак? (Потому что звук $u$ и сам всегда мягкий).

- Да, ребята, зачем же еще раз смягчать всегда мягкий 4 ?

- Следовательно, какой вывод мы можем сделать из данного наблюдения? (чк пишется без мягкого знака). 
- Правильно, ребята. Запомните, что не только чк, но и чн, ни пишутся всегда без мягкого знака. (Учитель демонстрирует опорную таблицу «Правописание чк, чн» (рис. 49), а обучающиеся хором читают написанное на ней правило).

На этапе закрепления материала детям предлагаются занимательные виды работы. Приведем примеры.

\section{Кроссворд}

Задание: «Решите небольшой кроссворд и скажите, что объединяет все разгаданные слова»

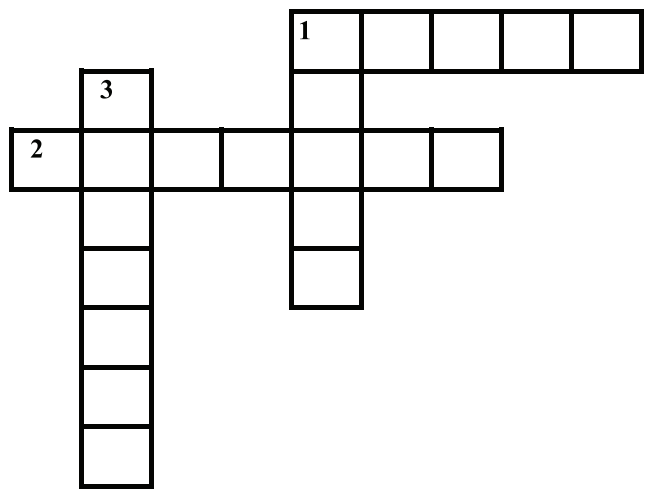

\section{По горизонтали}

1. Ее ставят в конце предложения (точка).

2. На ней носят кулон на шее (цепочка).

\section{По вертикали}

1. Маленькое грозовое облачко (тучка).

3. Продукт подсолнуха и тыквы (семечки).

Обучающиеся записывают разгаданные слова в тетрадях, дополняя их своими словами, которые подходят под заученное правило.

\section{Игра «Кто больше?»}

Трое-четверо ребят работают у доски - пишут столбиком слова на новую орфограмму. Среди них определяется победитель. Остальные работают в тетради и участвуют в исправлении ошибок обучающихся, работающих у доски.

Упражнение «Запись предложений с проговариванием и комментированием»

Пример предложения: Лавочка - это скамеечка со спинкой.

В дальнейшем учитель объясняет, что без мягкого знака пишутся и сочетания $-ч н,-н ч,-н щ,-p щ,-p ч$, и демонстрирует соответствующую опорную таблицу (рис. 50). 


\section{чк чн нч нщ рщ рч}

\section{$6 e 3 \mathrm{~b}$}

\section{дочка \\ барабанщик \\ фонарцик}

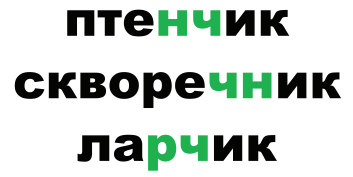

Рис. 50. Правила написания $-ч \kappa,-ч н,-н ч,-н щ,-р щ,-р ч$

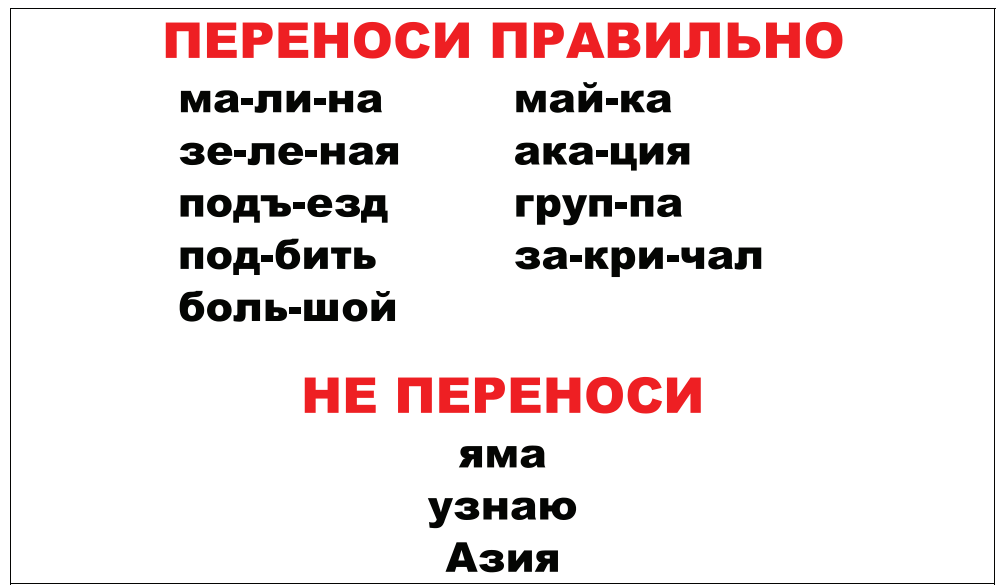

Рис. 51. Правила переноса слов

Сначала для усвоения правил переноса проводится подготовительная paбота. Учитель говорит обучающимся, что они уже умеют делить слова на слоги и правильно писать эти слова, проговаривая их по слогам, затем предлагает написать предложение, проговаривая слова по слогам, например: «У Саши живёт кот Пушок». Учитель интересуется, все ли слова поместились в одну строку (все). Далее учитель предлагает написать другое предложение. Учитель пишет на доске, а ученики - в тетрадях следующее предложение: «Моя большая Родина называется Россия». Обучающиеся какие-то слова в предложении не могут написать на строке полностью, учитель говорит о переносах. Например, требуется перенести на другую строку часть слова Россия. Учитель делит слово на слоги и демонстрирует возможный вариант 
переноса. Объясняются правила переноса и других слов. В результате объяснения на доске оформляется таблица.
Делим на слоги
Переносим
1) $P o c-c u-я$
Poc $-\underline{\underline{c}} \underline{=}$
2) $A-н я$
Аня (почему?)
3) $A-3 u-я$
Азия (почему?)
4) гpy $\underline{\underline{n}}-\underline{n} a$
гpy $\underline{\underline{n}}-\underline{\underline{n} a}$

Далее учитель демонстрирует опорную таблицу «Правила переноса слов» (рис. 51) и объясняет правила переноса слов. Обучающиеся рассматривают случаи переноса слов и делают выводы.

Закрепление усвоенного может проходить в виде соревнования «Кто лучше расскажет о правилах переноса?». Для закрепления этого материала также хорошо подходят физкультминутки, когда учитель называет слова, а дети хлопают в ладоши столько раз, сколько вариантов переноса. Если слово нельзя переносить, то обучающиеся не хлопают. Например:
1) страна - 1 хлопок;
2) садовод - 2 хлопка;
3) девочка - 2 хлопка;
4) Оля - нет хлопков.

\section{Мягкий знак b \\ у существительных после шипящих \\ M. P. \\ луч \\ Toвари도 \\ แasall \\ Ж. P. \\ मOبb \\ молодежь \\ ryallb}

Рис. 52. $b$ после шипящих у существительных 
Опорную таблицу «Б после шипящих у существительных» (рис. 52) можно использовать после усвоения обучающимися понятия о роде существительных.

При усвоении отраженного в таблице правила учитель указывает на слова в обоих столбцах и задаёт вопросы:

1. Что объединяет слова этих двух столбиков? (Все слова - имена существительные. Они оканчиваются на шипящие звуки).

2. Что объединяет слова каждого отдельного столбика? (В первом столбике существительные мужского рода, а во втором - женского рода).

3. Чем еще отличаются слова из первого столбца от слов из второго столбца? (В первом столбце у существительных мужского рода после шипящих мягкий знак не пишется, а во втором столбце у существительных женского рода - пишется).

4. Какую новую орфограмму мы можем в итоге сформулировать?

Обучающиеся самостоятельно или с помощью учителя формулируют заданное на опорной таблице правило, затем читают новое правило в учебнике и сравнивают его с выведенным в процессе обсуждения правилом.

При закреплении усвоенного материала учитель предлагает различные игры и упражнения. Приведем примеры.

Игра «Умники и умницы»

Учитель загадывает загадки, отгадывая которые следует руководствоваться правилом написания мягкого знака после шипящих:

1) птица, похожая на ласточку (стри);

2) темная половина суток (ночь);

3) сын царя (царевич);

4) она бывает устной и письменной (рецьь).

Физкульминутка

Учитель называет слова. Если у существительных в конце после шипящих пишется мягкий знак, то встают девочки, если не пишется - встают мальчики.

Письмо предложений с проговариванием и комментированием

Рыбаки расположились у озера на ноць. Они построили шалащ из еловых лапок. Их собака убежала в лес искать диu․

Обучающиеся называют существительные с шипящим в конце, обосновывают, почему они пишут его с мягким знаком или без него. Этот вид работы обязателен на каждом уроке русского языка, т. к. он развивает орфографическую зоркость. 


\section{«b» ПИШЕТСЯ}

\section{1) у существительных женского рода} 3 скл. (дочь, ночь, молодежь);

2) во 2 лице единственного числа глаголов (рисуешь, гуляешь);

3) у глаголов в неопределенной форме (жечь, беречь).

\section{«b" HE ПИШЕТСЯ}

\section{1) у существитель;ных не 3 скл. (нож_, задач_)}

\section{2) чк, чн, нч, нщ, щн, рщ, рч.}

Рис. 53. Б после шипящих

Таблица «Правила написания мягкого знака после шипящих» (рис. 53) используется для повторения и обобщения материала, после того, как усвоен материал по темам:

1) в у существительных женского рода;

2) изменение глаголов по лицам;

3) глаголы в неопределенной форме;

4) правописание чк, чн, нщ, рщ, нч;

5) существительные 1-го, 2-го, 3-го склонения.

Приведем примеры заданий для работы с данной таблицей по ее разделу «

Игра «Кто больше?» проводится после повторения первого пункта правила в таблице: $b$ пишется у существительных женского рода (правила проведения игры «Кто больше?» см. выше).

Упражнение на составление текста по опорным словам и письмо под диктовку проводится после повторения второго пункта правила на написание мягкого знака после шипящих: в пишется во 2 лице единственного числа глаголов (рисуешь, гуляешь).

Учитель предоставляет ряд слов для составления текста: гуляещь, наблюдаещь, увидищь, смотрищь возвращаешься. 
Обучающиеся с помощью учителя составляют по этим опорным словам текст, например:

Ты гуляешь по лесу летом. Во время прогулки ты наблюдаешь за яркой красотой природы, увидишь удивительные краски разных растений. С чувством восхищения ты смотришь на нежные ияеты. А потом возвращаешься домой счастливым и отдохнувшим.

По третьему пункту данного раздела таблицы после повторения правила «b пишется у глаголов в неопределенной форме (жечь, беречь)» так же, как и по первому пункту правила, может быть проведена игра «Кто больше?».

Приведем примеры заданий для работы с таблицей по разделу «Б не пишется».

После повторения правила первого пункта таблицы - «b не пишется у существительных не 3 скл.» - обучающиеся записывают в тетрадях приме-

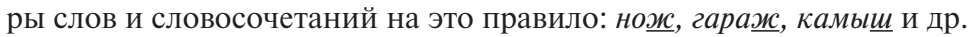

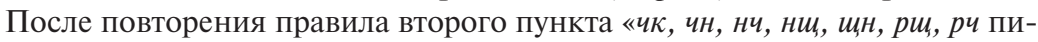
шется без мягкого знака» дети составляют предложения со словами, в которых есть эти стечения согласных, и записывают эти предложения, сопровождая запись комментированием.

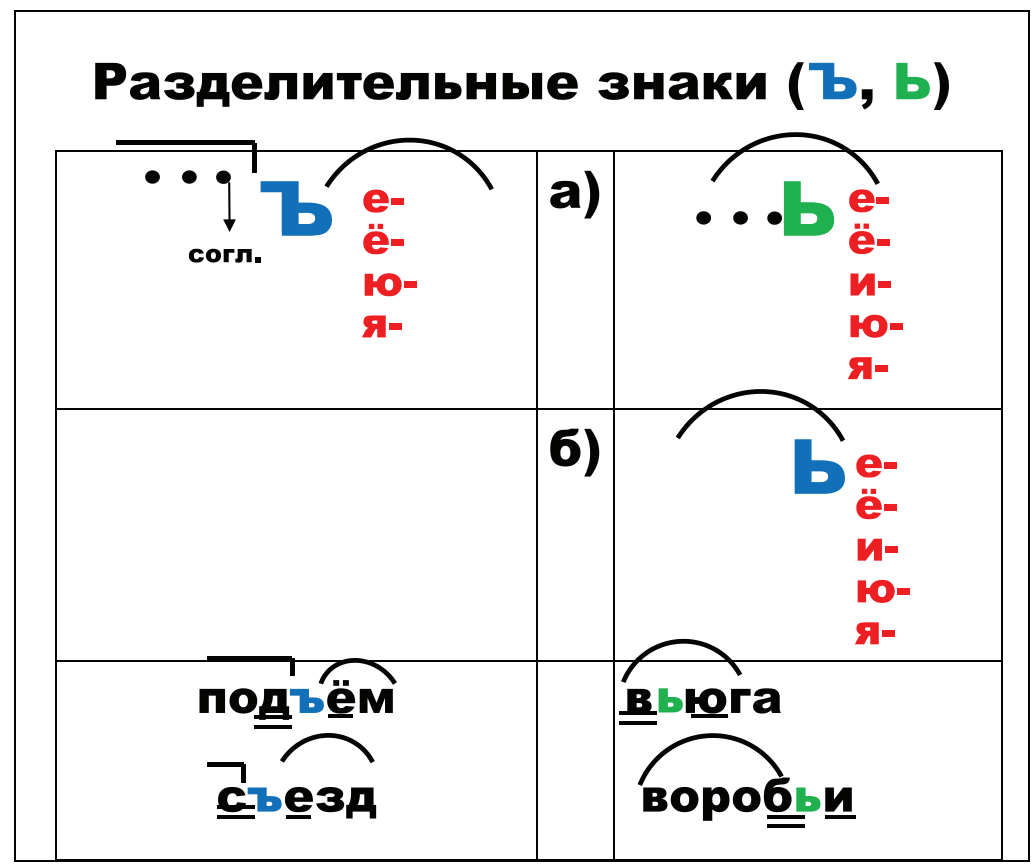

Рис. 54. Порядок разбора слов по составу 
Обобщение по орфограммам, отраженным в таблице (рис. 53), проводится в виде соревнования «Кто лучше расскажет правило?».

При объяснении новой темы обучающиеся изучают слова, написанные по орфограмме, отраженной в таблице «Порядок разбора слов» (таблица при этом пока не демонстрируется):

$\begin{array}{ll}\text { подвезд } & \text { ручьи } \\ \text { съехал } & \text { семья } \\ \text { подвём } & \text { вьюжнный }\end{array}$

- Что общего в словах первого столбца? (Слова написаны с ъ).

- А что общего в словах второго столбца? (Слова написаны с в).

- Давайте разберёмся, когда в словах следует писать разделительный ъ, а когда - разделительный $b$.

- Выделите корень в словах первого столбца (-езд-, -е-, -ём-).

- Какие части слова стоят перед корнем? (Приставки под-, $c$-).

- Какая буква последняя в приставке? (Согласная).

- Как произносятся последние согласные в приставках? (Мягко по московской норме и твёрдо в северном говоре).

- С какой буквы начинается корень в этих словах? (С гласных $е, \ddot{e})$. Еще в словах с разделительным з могут быть гласные -ю, -я.

- Сколько звуков обозначают эти буквы в начале корня? (Два: [и’э]).

- Сделайте вывод, в каких случаях в словах пишется разделительный ъ. (Разделительный з следует писать после приставок, которые оканчиваются на согласные, перед $-е,-\ddot{e},-ю,-я)$.

После формулировки вывода открывается левая часть опорной таблицы (рис. 51).

Аналогичная работа проводится по употреблению разделительного $b$. В итоге проведенной работы демонстрируется правая часть опорной таблицы.

Для закрепления материала используются игры и упражнения.

Игра «Чей рассказ лучше?»

Двое обучающихся рассказывают о правописании разделительных в и $b$. $B$ итоге выявляется победитель.

Игра «Кто больше?»

Дети с опорой на таблицу подбирают слова с $ъ$ и $b$ к каждой схеме из отраженных в таблице. 


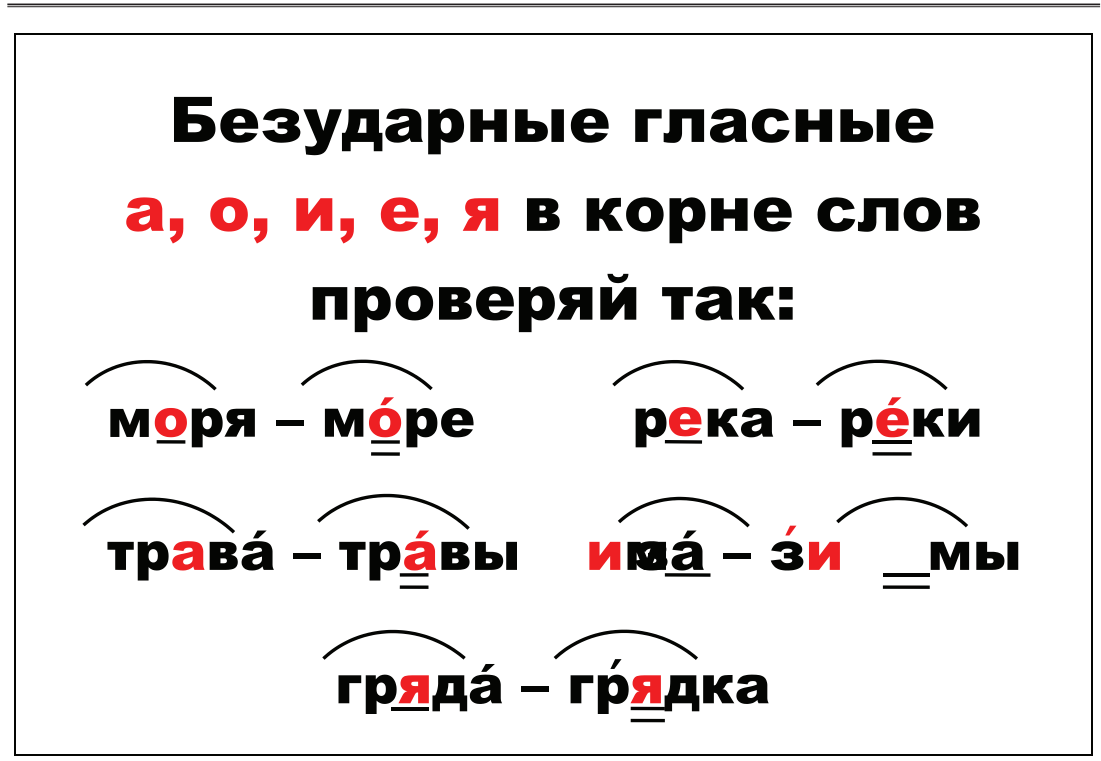

Рис. 55. Правописание безударных гласных в корне слова

Объясняя правописание безударных гласных в корне слова с опорой на таблицу (рис. 55), учитель, четко проговаривая и растягивая ударный слог в словах моря и море, задаёт вопросы:

- Какой гласный звук вы услышали в слове моря в безударном положении? (Неясный, нечёткий). А в слове море в ударном положении? (В ударном - четкий $o)$ ?

- Чем отличаются формы слов море и моря? (Числом). В каком числе находится слово моря? А слово море?

Таким же образом разбираются другие слова в таблице.

После проведенного разбора учитель задаёт следующие вопросы:

- Что интересного вы заметили, разбирая эти слова? (В разных формах одного и того же слова и в однокоренных словах безударные гласные пишутся так же, как в ударном положении).

- Как можно проверить правописание безударных гласных в корне слова? (Дети формулируют правило).

В процессе закрепления изученного обучающиеся выполняют упражнение на пройденную орфограмму, комментируя процесс проверки и написания слов с безударными гласными в корне, например: «Трава́. Ударный слог - ва́, в безударном слоге неясный звук, пишется то ли $a$, то ли $o$. Проверяю ударением: mpáвы. Под ударением слышим $a$, значит, без ударения пишем тоже $a »$. 


\section{ПАРНЫЕ ЗВОНКИЕ И ГЛУХИЕ СОГЛАСНЫЕ В КОРНЕ СЛОВА}

\begin{tabular}{|c|c|c|c|c|c|}
\hline $\boldsymbol{6}$ & $\mathbf{B}$ & $\mathbf{r}$ & $\mathbf{A}$ & $\mathbf{x}$ & $\mathbf{3}$ \\
\hline $\boldsymbol{n}$ & $\boldsymbol{\phi}$ & $\mathbf{K}, \mathbf{x}$ & $\mathbf{T}$ & $\mathbf{U}$ & $\mathbf{C}$ \\
\hline
\end{tabular}

проверяй так:
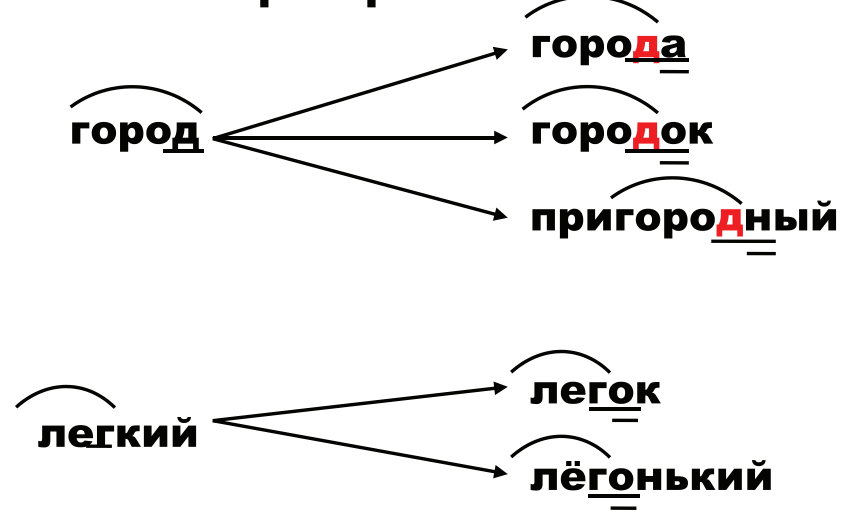

Рис. 56. Правила написания парных звонких и глухих согласных в корне слова

При изучении орфограммы, прежде чем демонстрировать учащимся таблицу «Правила написания парных звонких и глухих согласных в корне слова» (рис. 56), учитель может провести с обучающимися следующую беседу:

- Почему согласные первой строки назвали звонкими? (При произнесении звуков мы слышим голос и шум: [б - б'], [в - в'], [г - г'], [д - д’],[ж],[3-з'] шёпотом звонкие согласные нельзя произнести).

- Почему согласные второй строки назвали глухими? (звуки, обозначенные этими буквами, произносятся без голоса, только с шумом).

- Почему они парные? (Часто в словах вместо звонкого звука мы слышим глухой, например: город - горо $[\mathrm{m}])$.

- Какой вывод мы можем сделать? (При написании парные согласные необходимо проверять).

Учитель предлагает вниманию учащимися таблицу (рис. 56) и вместе с ними разбирает правописание согласных в корне слова на примере слова город: «Какой звук мы слышим в конце слова город? $([\mathrm{m} /)$. А во мн. ч. города и в словах городок, пригородный какой последний звук мы слышим в корне? ([д])». 
Таким же образом разбирается правописание парных согласных в словах зубки, зубы, зубок, зубной.

В итоге обучающиеся приходят к выводу, что парные согласные можно проверять с помощью гласных и сонорных, например $\boldsymbol{H}$, формулируют правило и сравнивают с правилом, написанным в учебнике.

На этапе закрепления материала обучающиеся выполняют упражнение на данную орфограмму с опорой на таблицу. При этом учитель даёт пример выполнения упражнения: «ллжкки. Корень слова - флаж

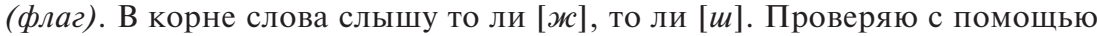
однокоренного слова флажок, в котором после сомнительного согласного идёт гласный $o$ » и т. д.

\section{Непроизносимые согласные}

\section{$A, T, B, J$}

в корне слова проверяй так:

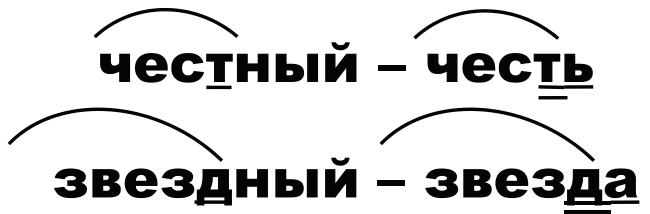

лестница

Запомни:

праздник

чувства

Рис. 57. Правописание непроизносимых гласных в корне слова

В процессе усвоения орфограммы, отраженной в таблице «Правописание непроизносимых гласных в корне слова» (рис. 57), учитель предлагает понаблюдать за произнесением и написанием слов, выделить в них корень:

солнышко - солнце

уста - устный. 
Затем обучающимся предлагается написать транскрипцию второго слова каждой пары:

солнце - [со́ниэ];

устный [у́сный]

Учитель обращает внимание обучающихся на то, что в этих словах они не услышали звуки [л] и [т], но при письме они их отразили. Учитель спрашивает детей, услышали ли они эти звуки в однокоренных словах солнышко и уста. Таким образом, формируется понятие о непроизносимых согласных. Обучающиеся формулируют правило проверки непроизносимых согласных с помощью учителя. Учитель отмечает, что есть слова, которые проверить с помощью этого правила невозможно, поэтому их надо запомнить: лестнииа, праздник, чувства (демонстрируется опорная таблица, хором повторяется правило).

На этапе закрепления материала можно проводить различные упражнения.

1. Учитель называет слова с непроизносимыми согласными, а обучающиеся называют однокоренные проверочные слова и выделяют непроизносимые звуки.

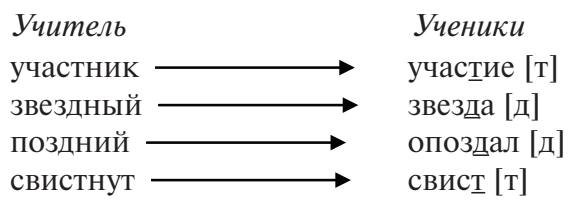

2. Запись предложений с непроизносимыми согласными под диктовку.

3. Запись текста с непроизносимыми согласными по памяти.

\section{ПРАВОПИСАНИЕ КОРНЯ}

\section{1. Безударные гласные}

2. Парные согласные

\section{3. Непроизносимые согласные}

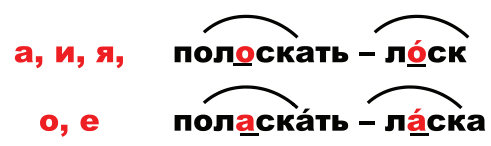

б, в, r, ж, ЛОВккость - лов̈ок
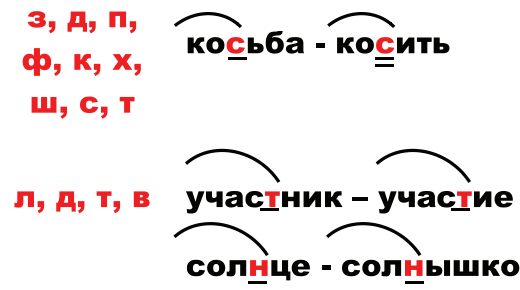

Рис. 58. Правописание гласных и согласных в корне слова 
Таблица на рис. 58 даёт возможность обобщить и сравнить правила корня.

Работая по первому пункту таблицы, учитель побуждает обучающихся к выяснению лексического значения слов до поиска проверочного слова для проверки безударных гласных, проверяемых ударением. Затем повторяются все три орфограммы по таблице (пункты 1, 2 и 3). Далее обучающиеся под руководством учителя составляют таблицу, отражающую сходства и различия проверки для трёх правил корня.

Приведем пример составленной таблицы.

Проверка корня

\begin{tabular}{|l|l|l|}
\hline & \multicolumn{1}{|c|}{ Сходство } & \multicolumn{1}{|c|}{ Различие } \\
\hline 1. Безударные гласные & $\begin{array}{l}\text { формами одного и того } \\
\text { же слова и однокорен- } \\
\text { ными словами }\end{array}$ & ударением \\
\hline 2. Парные согласные & $\begin{array}{l}\text { формами одного и того } \\
\text { же слова и однокорен- } \\
\text { ными словами }\end{array}$ & $\begin{array}{l}\text { гласными после со- } \\
\text { мнительных согласных } \\
\text { (пруд - пруди) }\end{array}$ \\
\hline $\begin{array}{l}\text { 3. Непроизносимые } \\
\text { согласные }\end{array}$ & $\begin{array}{l}\text { формами одного и того } \\
\text { же слова и однокорен- } \\
\text { ными словами }\end{array}$ & $\begin{array}{l}\text { гласными после со- } \\
\text { мнительных согласных } \\
\text { (честный - честен, } \\
\text { полезный - полезен) }\end{array}$ \\
\hline
\end{tabular}

\section{ЗАПОМНИ! \\ CH 6eз T}

ужасный

прекрасный

напрасный

интересный опасный

вкусный

чудесный

\section{чудесный - чудеса}

Рис. 59. Правописание $-c H,-3 H$ 
В процессе изучения новой темы учитель напоминает правила о проверке непроизносимых согласных в корне слова и обращает внимание обучающихся на то, что чаще всего непроизносимый согласный находится между звуками [c] и [н] - [стн], [3] и [н] - [здн]. Затем учитель просит привести примеры таких слов и подобрать проверочные слова к ним, например: лестный - лесть, местный - место и др.

Учитель говорит, что в русском языке есть слова, в которых $m$ между стечением согласных -сн и -зн нет, демонстрирует таблицу «Правописание $-c н,-3 н »$ (рис. 59) и просит детей попробовать найти к написанным в таблице словам проверочные слова. В результате обучающиеся приходят к выводу, что отсутствие т в этих словах можно и проверить, например: ужасный ужасен; прекрасный - прекрасен и др.

Для запоминания этих слов учитель заучивает с обучающимися стихотворение:

В ужкасный и опасный век

Жил интересный человек.

Растил он свой прекрасный сад,

Чудесный вкусный виноград.

Здесь смысл искать напрасный труд,

Писать без Т ты не забудь.

Закрепление материала может также проходить в виде упражнений, игр и соревнований между обучающимися.

\section{ОЛО - OPO}

\section{всегда пиши с 0}

молоко, колонка,

болото, олово,

полоса, волосы,

голос, голова,

полотно, полотенце корова, воробей,

мороженое, дорога,

сорока, ворона,

ворота, город,

мороз, хорошо

Рис. 60. Правописание слов с -оло-, -оро-

При изучении орфограммы, отраженной в таблице «Правописание слов с -оло-, -оро-» (рис. 60), Учитель просит обучающихся вспомнить, как проверяются безударные гласные (с помощью подбора однокоренных слов, 
в которых безударный гласный становится ударным). Далее учитель пишет на доске несколько слов с -оло и -оро, один из безударных гласных в которых невозможно проверить с помощью этого правила, например: молоко, волоcb, дорога, хорошо. Учитель говорит, что это словарные слова с сочетаниями -оло и -оро и надо запомнить орфограмму (учитель демонстрирует таблицу «Правописание слов с -оло-, -оро-»), а обучающиеся делают вывод о том, что слова с сочетаниями -оло и -оро всегда пишутся с $о$.

Для закрепления орфограммы можно записать предложения с проговариванием и комментированием. Полезно провести проверочный диктант, в тексте которого представлены слова с сочетаниями -оло и -оро.

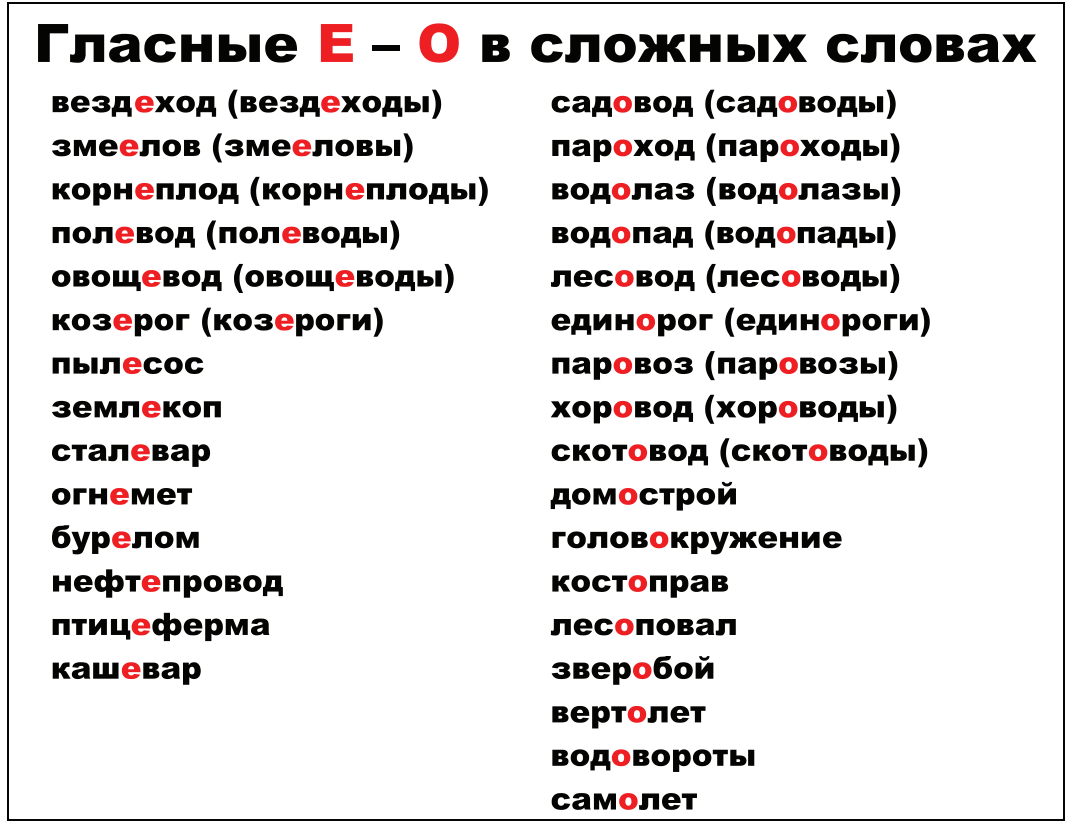

Рис. 61. Соединительные $о$ и $е$ в сложных словах

Обучающиеся последовательно читают по указанию учителя слова первого и второго столбцов таблицы «Соединительные $o$ и $e$ в сложных словах» (рис. 61) и отвечают на вопросы: «Что объединяет слова первого столбца? Второго столбца?». После выводов о том, что это сложные слова, и в первом столбце корни двух слов соединены $e$, а во втором - $o$, задаётся вопрос: «Почему в первом столбце корни слов соединены гласной $e$, а втором - гласной $o$ ?». Обучающиеся должны прийти к выводу, что в первом столбце последняя согласная корня первого слова обозначает мягкий звук, а во втором - твёрдый звук. На этом 
основании формулируется следующее правило: если в сложных словах, состоящих из двух корней, последняя согласная первого корня обозначает мягкий звук, шипящий и $u$, то пишется соединительная буква $e$, а если последняя согласная первого корня обозначает твёрдый звук, то пишется соединительная буква $o$.

Далее учитель просит внимательно прочитать слова первого столбика и найти два слова, которые составляют исключение из сформулированного правила. Обучающиеся должны выделить такие слова, как птицеферма и кашевар и сформулировать еще один вывод о том, что в случае, если последней согласной первого корня является согласная, не имеющая парной мягкой согласной, всегда пишется соединительная $e$.

\section{ПРИСТАВКИ ПИШИ СЛИТНО!}

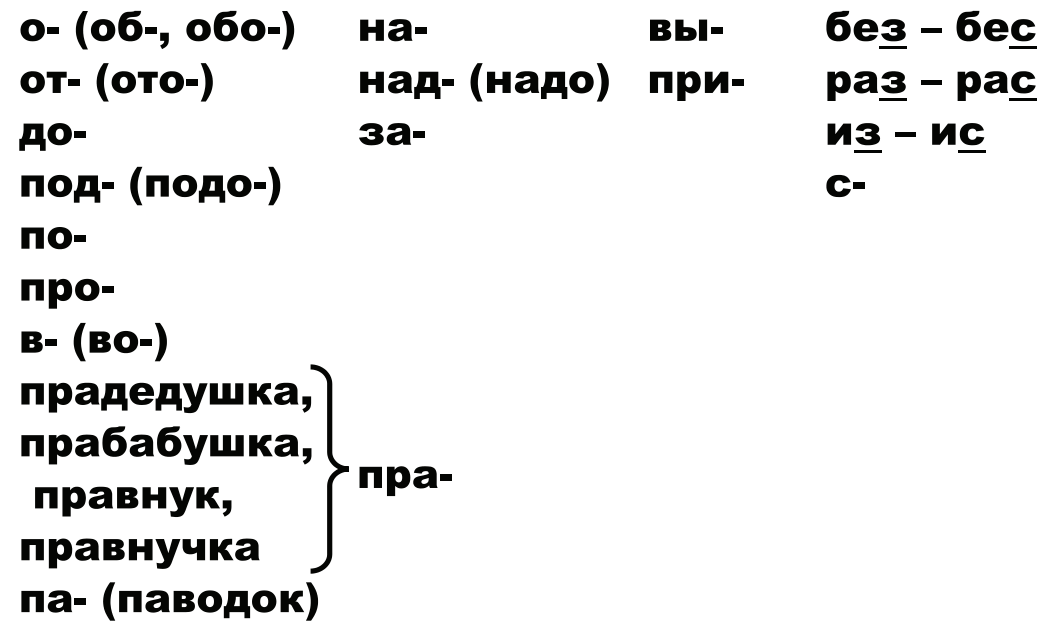

Рис. 62. Правило написания приставок

В процессе предварительной работы перед изучением правописания приставок учитель проводит беседу:

- Вспомните, что такое приставка. (Часть слова, которая стоит перед корнем и образует однокоренные слова с новым значением). 
- Если приставка - это часть слова, как ее следует писать? (Слитно, ее нельзя отделять от корня).

- Сравните приставки в словах о́крик и осмо́mp. Какие гласные в эти приставках? (В слове окрик гласная $о$ в приставке ударная, а в слове осмотр безударная).

Какой вывод можно сделать на этом основании? (Ударные и безударные гласные пишутся в большинстве приставок независимо от произношения одинаково, хотя есть исключения: раз - pac). Приведите свой пример и докажите это.

Далее учитель демонстрирует опорную таблицу «Правило написания приставок» (рис. 62) и проводит объяснение: «Посмотрите, на первый столбец таблицы до фигурной скобки. Что общего в этих приставках? (Все они пишутся с гласной o). Вывод: в приставках o-, oб-, om-, omo-, до-, no-, nод-, nодо-, про-, во- независимо от произношения всегда пишется буква $о$. Приставка пра- пишется только в словах прадедушка, прабабушка, правнук, правнучка, пращур, прародина, а приставка па- - в словах паводок, пасынок, падщерица». Учитель просит обучающихся подобрать слова с приставками из первого столбца и записать их в тетради.

Учитель переходит к объяснению материала по приставкам второго столбца: «Что общего в приставках второго столбца? (Все приставка пишутся с буквой $a$ ). Приведите примеры слов с этими приставками. Обратите внимание на ударные и безударные гласные в этих приставках и сделайте вывод. (В приставках на-, над-, за- всегда пишется только буква $a$ )».

Перед объяснением правил написания приставок последнего столбца учитель просит написать слова с этими приставками в два столбца:

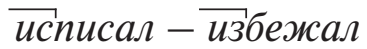 \\ бескровный - безграмотный \\ бессовестный - беззлобный}

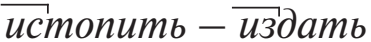

Учитель просит прочитать слова первого второго столбца и говорит: «Посмотрите, какие согласные стоят в корне слов первого столбца после приставки (глухие). А какие согласные в корне слов второго столбца стоят после приставки? (Звонкие). Следовательно, если в начале корня после приставок без-, бес-, paз-, pac-, из-, ис- стоит звонкий согласный, то в приставке пишется звонкая 3, а если в начале корня стоит глухой согласный, то в приставке пишется с. Исключение составляет приставка $c$-. Так, в слове сделать - начальный согласный в корне слова звонкий $\partial$, но пишем приставку c-. Приставки з- не бывает». 
Разбирая правило написания приставок третьего столбца, учитель предлагает учащимся написать слова с приставками $\boldsymbol{в}$-, вы- и подводит их к выводу, что приставка может произноситься со звуком [ф], но пишется буква $в$.

В качестве упражнений для закрепления материала можно использовать запись предложений с комментированием правописания приставок при опоре на таблицу.

\section{5. Таблицы для изучения раздела «Предложение»}

\section{ЧЛЕНЫ ПРЕДЛОЖЕНИЯ}

сущ., мест.

Подлежащее (кто? что?)

глаг.

Сказуемое (что делает?)

прилаг., мест.

Oпределение (какой? чей?)

сущ., мест.

Дополнение (падежные вопросы)

нареч., сущ.

обстоятельство (где? когда? откуда? как?)

Рис. 63. Члены предложения

В процессе объяснения материала учитель предлагает учащимся рассмотреть опорную таблицу «Члены предложения» (рис. 63) и проводит следующую беседу:

- Какие члены могут быть в предложении? (Подлежащее, сказуемое, определение, дополнение, обстоятельство).

- Прочтите предложение, написанное на доске. (Сегодня мороз запорошил деревья мягким снежком).

- О чём говорится в предложении? (О морозе).

- Это подлежащее. Подлежащими чаще всего бывают существительные и местоимения.

- На какие вопросы отвечает подлежащее? (Кто? Что?). Подлежащее подчёркивают одной линией. 
- Обычно в предложении что-то говорится о предмете, который является подлежащим. Что говорится в этом предложении о морозе (что он запорошил снежком деревья)? Что он сделал? (Запорошил).

- То, что сказано о подлежащем, назвали сказуемым. Сказуемое отвечает на вопросы что делал? что сделал? что делает? и т. д. Сказуемое в предложении обозначается двумя линиями.

- Мороз запорошил чем? (Снежком). Слово снежком дополняет мысль - чем были запорошены деревья, поэтому его назвали дополнением. Дополнения отвечают на все падежные вопросы, кроме и. п. Его обозначают пунктирной линией.

- Снежком каким (мягким)? Слово мягкий определяет признак предмета, поэтому это слово называют определением. Определения в предложении отвечают на вопросы какой? чей? который? Их обозначают волнистой линией. В предложении он могут быть выражены прилагательными и местоимениями.

- Запорошил когда? (Сегодня). Слова, отвечающие в предложении на вопросы когда? где? куда? как? откуда?, обозначают время, способ, место действия. Эти члены предложения называют обстоятельствами. Обстоятельство в предложении обозначается пунктиром с точкой. Они могут выражаться существительными, наречиями и другими способами.

Учитель также обращает внимание обучающихся на то, что в этом предложении есть все члены предложения, обозначенные в опорной таблице, однако в других предложениях какие-то члены предложения могут отсутствовать или повторяться.

В качестве средства закрепления материала, как обычно, могут использоваться игры и упражнения. Приведем в качестве примера одну из игр.

Игра «Кто быстрее?»

Учитель называет вопрос, а обучающиеся - член предложения, который к нему относится (или наоборот).

\begin{tabular}{|c|c|}
\hline Учитель & Обучающиеся \\
\hline Кого? & дополнение \\
\hline О чём? & дополнение \\
\hline Где? & обстоятельство \\
\hline Кто? & подлежащее \\
\hline Какой? & определение \\
\hline Что делает? & сказуемое \\
\hline Когда? & обстоятельство \\
\hline
\end{tabular}




\title{
ПРЕДЛОЖЕНИЕ
}

главные

членын

\author{
KTO? \\ подлежащее \\ 4TO? \\ 4 TTO
}

сказуемое

делает?

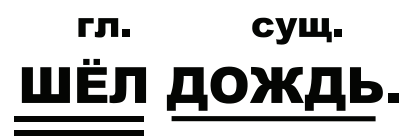

\section{Сегояння шёл мелкий дождь.}

\section{второстепенные - все остальные слова в предложении}

Рис. 64. Главные и второстепенные члены предложения

Учитель напоминает тему, которая изучалась с опорой на предыдущую опорную таблицу (рис. 63) и просит перечислить члены предложения, назвать вопросы, на которые они отвечают, и описать их роль в предложении. Этот приём позволяет повторить пройденный материал и подготовить обучающихся к восприятию новой темы.

Учитель демонстрирует опорную таблицу «Главные и второстепенные члены предложения» (рис. 64) и объясняет материал следующим образом:

- Прочитайте предложение в таблице. (Сегодня шёл мелкий дождь).

- Найдите главные члены предложения (шел, дождь).

Понятна ли основная мысль предложения только по главным членам? (Понятна). Поэтому их называют главными членами предложения. Они составляют основу предложения.

- А какую роль выполняют слова мелкий и сегодня? Они дополняют признак предмета (подлежащего) и время действия (глагола). Все остальные слова, кроме подлежащего и сказуемого, называются второстепенными членами предложения. 
В качестве средства закрепления материала может использоваться запись текста с комментированием всех изученных орфограмм и последующим выделением главных членов предложений и называнием второстепенных.

Весной в лесу

Пригрело весеннее солние. С пригорка побежали веселье ручьи.

Опустели зимние квартиры в старых пнях. Выползли из-под коры жучки и букашки. Выбралась ящерица из норки. Лягушки тоже очнулись от зимнего сна. Они запрыгали по лужам.

Вся природа очнулась от зимней спячки.

\section{РАЗБОР ПРЕДЛОЖЕНИЯ ПО ЧЛЕНАМ ПРЕДЛОЖЕНИЯ Высоко в небё плыли белье барашки ӧб}

\section{барашки (какие?) белые барашки (чего?) облаков плыли (где?) в небебе плыли (как?) выцс.око}

Рис. 65. Разбор предложения по членам предложения

Учитель предлагает обучающимся вспомнить материал, который разбирался посредством таблиц «Члены предложения» и «Главные и второстепенные члены предложения» (рис. 63, 64) и проводит подготовительную работу к ознакомлению с новой темой следующим образом:

- Какие члены предложения вы знаете?

- Как находят подлежащее? (По вопросам кто? или что?).

- Как находят сказуемое? (В предложении что-то говорится о предмете, его действии).

- Как находят второстепенные члены предложения? (К ним ставят вопросы от связанных с ними слов). 
В процессе объяснения материала учитель даёт образец разбора предложения с комментированием на доске:

1. На опушке леса отцветает земляника. О чём говорится в предложении? О землянике. Что? Земляника. Это подлежащее, обозначаю его одной чертой.

2. Что говорится о землянике? Она отцветает. Что делает? Отцветает. Это сказуемое. Земляника отцветает - основа предложения.

3. Земляника какая? Сладкая. Сладкая обозначает признак земляники. Значит, это определение. Подчёркиваю его волнистой линией.

4. Отцветает где? На опушке. Обозначает место действия. Это обстоятельство. Подчёркиваю пунктирной линией с точкой.

5. На опушке чего? Леса. Обозначает предмет. Существительное находится в косвенном падеже, значит, это дополнение. Обозначаю его пунктирной линией.

После проведенного разбора обучающимся демонстрируется таблица «Разбор предложения по членам предложения» (рис. 65), и они проводят разбор предложения с опорой на таблицу и образец учителя.

В качестве средств закрепления материала используются упражнения по разбору различных предложений, предложенных учителем и придуманных детьми.

\section{ОДНОРОДНЫЕ ЧЛЕНЫ ПРЕДЛОЖЕНИЯ}
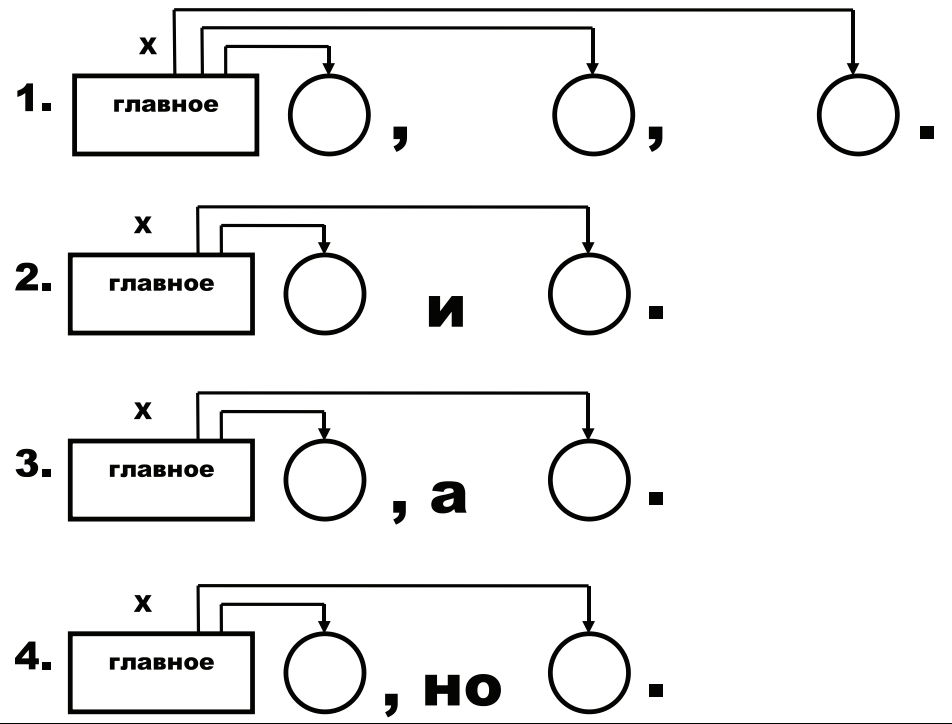

Рис. 66. Однородные члены предложения 
Прежде чем начинать работу по опорной таблице «Однородные члены предложения» (рис. 66), учитель объясняет новый материал следующим образом:

- Прочитайте предложение на доске: Тучи плывут над землей, над рекой, над озером.

- Найдите основу предложения. (Тучи плывут).

- Найдите словосочетания в этом предложении. (Плывут (где?) над землей, плывут (где?) над рекой, плывут (где?) над озером).

- Что интересного заметили в этих словосочетаниях? (Во всех словосочетаниях используется одно и то же главное слово плывут. Все зависимые слова отвечают на один и тот же вопрос и относятся к одному и тому же главному слову).

- Какими членами предложения являются зависимые слова? (Обстоятельствами).

- Слова, которые отвечают в предложении на один и тот же вопрос и зависят от одного и того же слова, называются однородными членами предложения. Однородными могут быть любые члены предложения.

Учитель знакомит обучающихся с опорной схемой (рис. 66) и просит построить схему по разбираемому предложению.

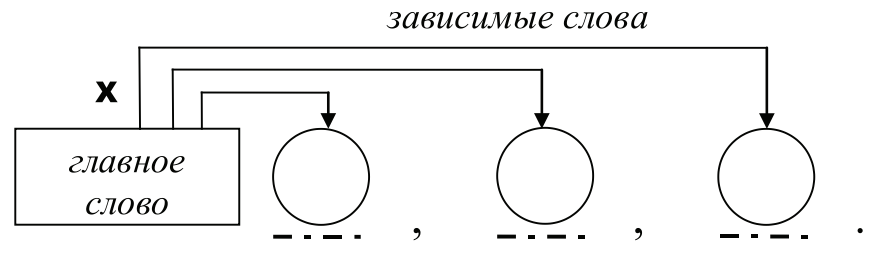

- Однородные слова связаны интонацией перечисления. Какие знаки препинания стоят между однородными членами предложения (запятые)?

- Прочитайте следующее предложение. (За этот год деревья в моём саду выросли и окрепли).

- Найдите в этом предложении слова, которые зависят от одного слова и отвечают на один и тот же вопрос. (Деревья (что сделали?) выросли и окрепли).

- Как мы их называем? (Однородными членами).

- Какими членами предложения они являются? (Сказуемыми).

- Кроме интонации перечисления между ними есть союз $u$. Если союз и в предложении не повторяется, то между однородными членами запятая не ставится.

- Какую схему этого предложения можно построить?

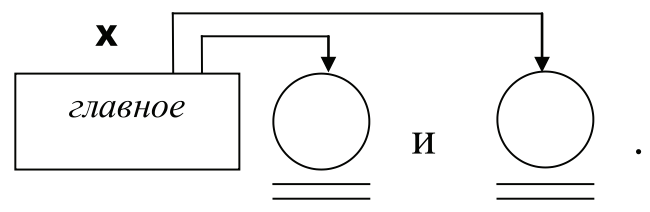


Затем также разбирается предложение «За этот год деревья в моём саду и выросли, и окрепли». Объясняется наличие в предложении знаков препинания, строится схема предложения.

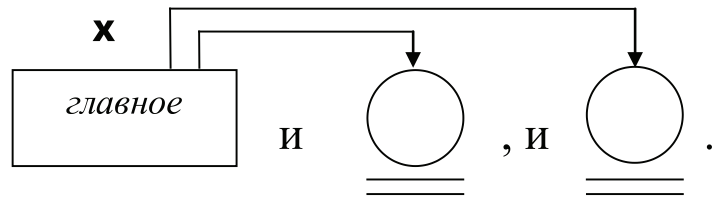

После этого учитель предлагает обучающимся самостоятельно составить и записать в тетради предложения с однородными членами, объединенными союзами а, но по 3 и 4 схемам таблицы «Однородные члены предложения» .

В качестве средства закрепления материала предлагается вспомнить предложения с однородными членами из прочитанных произведений на уроках литературного чтения. Понравившиеся предложения класс записывает в тетради с комментированием всех пройденных орфограмм. После записи обучающиеся находят однородные члены предложения и объясняют расстановку знаков препинания при них. 


\title{
Гдава 2. ТАБЯИЦЫ НА УРОКАХ МАТЕМАТИКИ
}

\author{
2.1. Табдицы ддя изучения нумерации \\ и выподнения арифметических действий
}

\begin{tabular}{|rrrrrrrrrr|}
\hline & 1 & 2 & 3 & $\mathbf{4}$ & $\mathbf{5}$ & $\mathbf{6}$ & $\mathbf{7}$ & $\mathbf{8}$ & $\mathbf{9}$ \\
10 & 11 & 12 & 13 & 14 & 15 & 16 & 17 & 18 & 19 \\
20 & 21 & 22 & 23 & 24 & 25 & 26 & $\mathbf{2 7}$ & 28 & 29 \\
30 & 31 & 32 & 33 & 34 & 35 & 36 & 37 & 38 & 39 \\
40 & 41 & 42 & 43 & 44 & 45 & 46 & 47 & 48 & 49 \\
50 & 51 & 52 & 53 & 54 & 55 & 56 & 57 & 58 & 59 \\
60 & 61 & 62 & 63 & 64 & 65 & 66 & 67 & 68 & 69 \\
70 & 71 & 72 & 73 & 74 & 75 & 76 & $\mathbf{7 7}$ & 78 & 79 \\
80 & 81 & 82 & 83 & 84 & 85 & 86 & 87 & 88 & 89 \\
90 & 91 & 92 & 93 & 94 & 95 & 96 & 97 & 98 & 99 \\
100 & & & & & & & & & \\
\hline
\end{tabular}

Рис. 67. Сложение и вычитание в пределах 100

Таблица «Сложение и вычитание в пределах 100» (рис. 67), позволяет легко находить число, образованное путем сложения и вычитания десятков и единиц, присчитывания и отсчитывания по одной единице и десятками. В верхней строке (черные цифры) находятся единицы, в левом столбце (красные цифры) - десятки. В таблице двухзначных чисел десятки также обозначаются красным цветом, единицы - черным. Поиск числа при присчитывании производится стандартно так же, как и по другим таблицам сложения и умножения. Так, суммой чисел 10 и 1 является 11, суммой чисел 5 и 70 является 75 и т. п. Подобным образом производится и отсчитывание по одному: $12-1=11$; $94-1=93$ и т. п. Таким образом при присчитывании по одному взгляд движется по строке слева направо, а при отсчитывании, - напротив, справа налево.

Посредством этой таблицы также можно узнать, как из любого двузначного числа вычитаются все его единицы или все его десятки.

Если из любого двузначного числа вычитаются все его единицы, ответ находят на самом первом левом) столбце (от 10 по 90), а при вычитании из 
любого двузначного числа всех его десятков, ответ находят на первой верхней строке (от 1 до 9). Например: $64-4=60$ или $64-60=4$. Если необходимо прибавить к любому двузначному числу круглые двухзначные числа (20, 30, 40 и т.д.) следует работать по вертикальному столбцу: от первого слагаемого идти на нужное количество десятков вниз. При вычитании круглых двухзначных чисел, напротив, надо идти от уменьшаемого по столбцу вниз.

Таблица даёт возможность производить сложение и вычитание и некруглых двузначных чисел. Например, при решении следующего примера: $34+25$ следует от числа 34 опуститься на 2 строки вниз, т. е. на два десятка, а затем двигаться по этой строке слева направо на 5 единиц, получается число 59. Вычитание производится аналогичном способом, только в других направлениях, например: при решении примера 67 - 33 следует от числа 67 подняться вверх на 3 строки и пойти справа налево на 3 единицы, получается число 34.

По этой таблице учитель может давать задание на сложение и вычитание с переходом через десяток.

\section{ДЕЛЕНИЕ НА РАВНЫЕ ЧАСТИ}
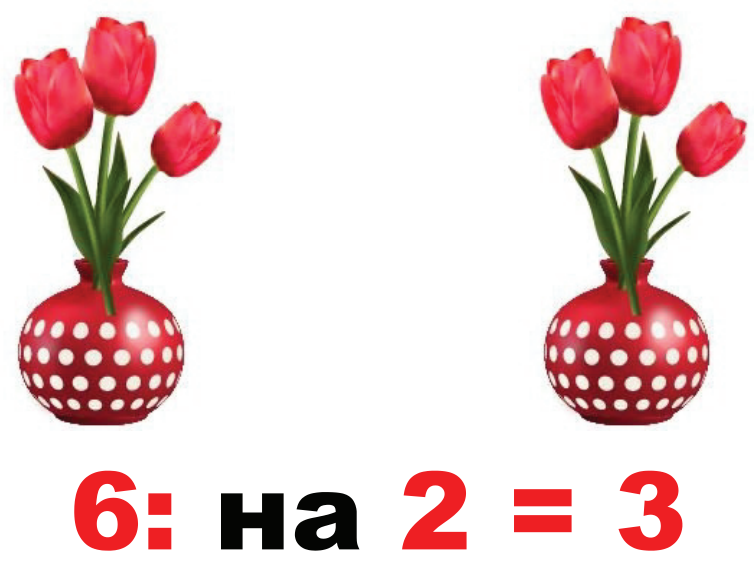

Рис. 68. Деление на равные части

Таблица «Деление на равные части» (рис. 68) направлена на формирование понимания того, что числа могут быть поделены на равные части. Способ деления демонстрируется на примере числа 6: «6 - это 2 раза по 3». После того, как формулировка усвоена и составлен пример, учитель вместе 
с обучающимися составляет и решает подобные задачи: «На какие две части можно поделить горсть из 6 конфет (8 карандашей, 10 леденцов)?». После этого учитель задаёт вопрос о том, можно ли делить количество на 3, 4, 5 частей. Затем обучающимся предлагаются прежние и новые задачи на деление на равные части: «На сколько еще равных частей можно поделить 6 цветков (6 яблок, 8 карандашей, 10 леденцов)?», «На сколько равных частей можно поделить 9 огурцов (9 книг)?».

Обучение решению уравнений проводится после того, как обучающиеся хорошо усвоили названия компонентов арифметических действий сложения и вычитания, а также способы вычисления каждого из компонентов в связи с другими компонентами арифметического действия, что можно увидеть на таблицах, представленных на рис. 69-70.
$6+3=9$
$x+3=9$
$6+x=9$
6 - слагаемое
$x=9-3$
$x=9-6$
3 - слагаемое
$x=6$
$x=3$
9 - сумма
$6+3=9$
$6+3=9$
$9=9$
$9=9$

сумма = слагаемое + слагаемое

слагаемое = сумма - слагаемое

Рис. 69. Усвоение компонентов при действии сложения и решение уравнения с неизвестными слагаемыми
$9-3=6$
$x-3=6$
$9-x=6$
9 - уменьшаемое $x=6+3$
$x=9-6$
3 - вычитаемое $\quad x=9$
$x=3$
6 - разность
$9-3=6$
$9-3=6$
$6=6$
$6=6$

уменьшаемое = разность + вычитаемое вычитаемое = уменьшаемое - разность

Рис. 70. Усвоение компонентов при действии вычитания и решение уравнения с неизвестным уменьшаемым и вычитаемым 


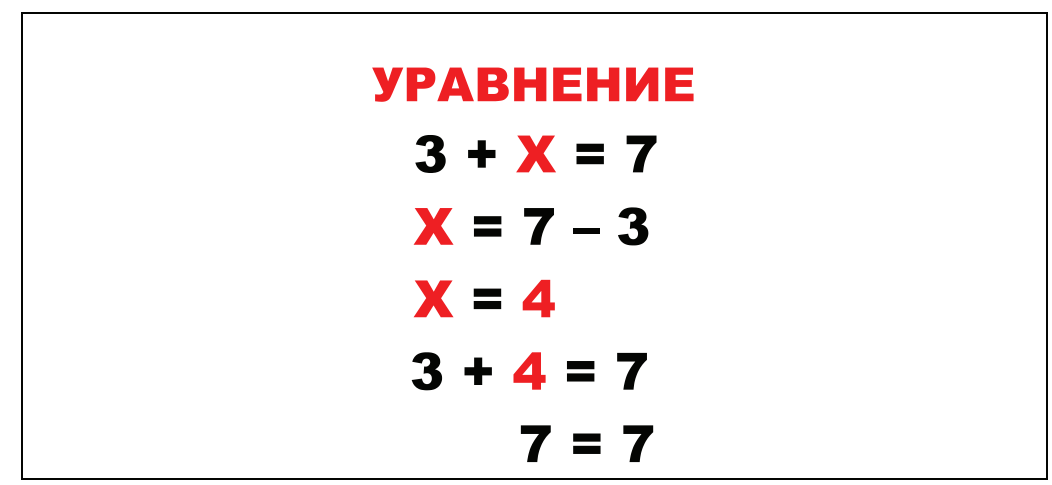

Рис. 71. Решение уравнения и проверки правильности его решения

Таблица «Решение уравнения и проверки правильности его решения» (рис. 71) отражает правила решения уравнения и проверки правильности его решения. Учитель может использовать эту таблицу для заучивания наименований компонентов уравнения и для нахождения неизвестных компонентов, а также для обучения проверке правильности найденного решения.

\section{2. Табдицы для изучения мер}

\section{МЕРЫ ДЛИНЫ \\ $1 \mathrm{KM}=1000 \mathrm{M}$ \\ $1 \mathrm{M}=10$ дм \\ 1 дм = $10 \mathrm{~cm}$ \\ $1 \mathrm{~cm}=10 \mathrm{Mm}$ \\ $1 \mathrm{M}=100 \mathrm{~cm}=1000 \mathrm{~mm}$}

Рис. 72. Меры длины

Отображенная на рис. 72 таблица позволяет сформировать у обучающихся знание о соотношении единиц измерения длины, увидеть, в каком соотношении одна мера представлена в другой. С опорой на данную таблицу дети могут решать задачи, в которых одновременно представлены разные меры длины, например метры и дециметры, километры, метры и сантиметры. 
Приведем примеры таких задач.

Дана следующая задача: «Длина стола учителя составляет 1 метр. Длина стола ученика на 33 сантиметра меньше. Какова длина стола ученика?». Сначала учитель обращает внимание учеников на то, что в задаче даны разные меры длины, подводит класс к поиску способа решения стоящей проблемы: данные в задаче надо представить в одной мере длины. В частности, в этой задаче 1 метр превращается в 100 сантиметров, и лишь затем производится действие по поиску длины стола ученика: $100-33=67$.

Подобным образом производятся вычисления в других задачах с данными, представленными в разных мерах длины.

\section{PАССТОЯНИЕ - километры (км), метры (м) ДЛИНА, ШИРИНА, ВЫСОТА, РОСТ - метры, дециметры, сантиметры \\ 1 километр (км) - 1000 метров (м) \\ 1 метр (м) \\ 1 дециметр (дм) \\ 1 метр (м) \\ 1 сантиметр (см) \\ - 10 дециметров (дм) \\ - 10 сантиметр (см) \\ - 100 сантиметров (см) \\ - 10 миллиметров (мм)}

Рис. 73. Меры измерения расстояния и длины

Таблица, представленная на рис. 73, позволяет усвоить символичное обозначение мер расстояния и длины, дифференцировать те единицы измерения, с помощью которых можно измерять расстояние, а с помощью которых - длину, ширину, высоту, рост. Помимо этого, эта таблица так же, как и предыдущая, позволяет соотнести единицы измерения расстояния, длины, ширины, высоты, роста. Так, с помощью данной таблицы можно решать задачи как на сложение и вычитание, так и на умножение и деление. Приведем пример одной из задач на вычисление расстояния между пунктами: «Расстояние от дома до автовокзала 2 км 300 м, а расстояние от дома до соседнего села в 3 раза больше. На сколько километров расстояние от дома до соседнего села больше, чем расстояние от дома до автовокзала». Эта задача решается в два действия. Для ее решения следует произвести следующие действия:

1) с опорой на таблицу перевести километры в метры;

2) вычислить расстояние от дома до села;

3) вычислить разность двух расстояний - от дома до села и от дома до автовокзала; 
4) полученный в метрах ответ с опорой на таблицу перевести в километры и метры.

Учитель показывает классу, что эту задачу можно решить и без перевода километров в метры, однако указывает на то, что бывает много случаев, когда без преобразования мер длины задачу решить сложнее, и приводит примеры таких задач.

\section{МЕРЫ МАССЫ (ВЕС) \\ тонна, центр, килограмм, грамм}

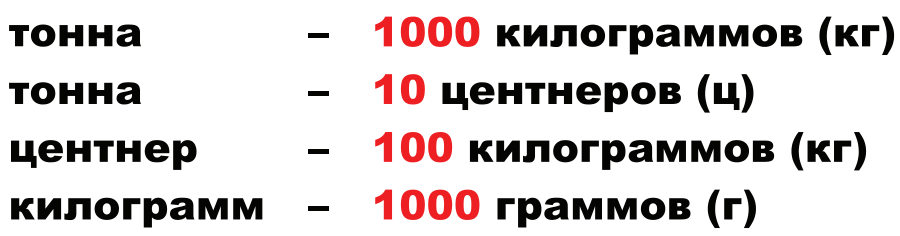

Рис. 74. Меры измерения массы

Таблица «Меры измерения массы» (рис. 74) отражает соотношения мер массы (веса), т. е. сколько мер веса в одной единице представлено в другой единице измерения. Так, если тонну отмерять в килограммах, то в ней содержится 1000 кг, а если в центнерах - то 10 ц. Центнер, в свою очередь, содержит 100 килограммов, а килограмм - 1000 граммов.

До усвоения знаний о соотношении мер массы учитель должен дать обучающимся представление о каждой из мер массы: что такое грамм, килограмм, центнер, тонна.

С опорой на таблицу учитель может давать задания на вычисление мер массы, например:

1. Сколько килограммов содержится в 12 центнерах (3 тоннах)?

2. Сколько граммов содержится в 2 килограммах?

3. Запишите 3000 килограммов в центнерах (тоннах).

4. Запишите 2000 граммов в килограммах.

По мере усвоения умения выполнять задания на определение мер массы, выраженных в натуральных числах, даются задания на оперирование с дробными числами массы:

1. Сколько килограммов содержится в 2,5 центнера (1,7 тонны)?

2. Сколько граммов содержится в 0,5 килограмма (1,2 килограмма)?

3. Запишите 5,4 центнера в килограммах (тоннах).

4. Запишите 7800 граммов в килограммах. 
Далее даются более сложные задачи, которые включают оперирование сразу несколькими единицами измерения веса:

1. Запишите 2 тонны и 3 центнера в килограммах.

2. Запишите 2 килограмма 35 граммов в граммах.

\section{ЕДИНИЦЫ ВРЕМЕНИ}

\section{1 век = 100 лет \\ 1 год = 12 мес. \\ 1 год = 365 или 366 суток \\ 1 мес. = 30 (31) суток (сутки) \\ 1 сут. = 24 4. \\ 1 ч. = 60 мин. \\ 1 мин. = 60 сек.}

Рис. 75. Соотношение единиц времени

Таблица «Соотношение единиц времени» (рис. 75) может использоваться в качестве опорной при решении задач на время. Таблица также позволяет понять, что ответ на решение задачи может разниться в зависимости от того, какое количество единиц за основу мы берём в единицах времени «год» (365 или 366 суток) и «месяц» (30 или 31 сутки).

Могут быть предложены следующие задачи:

1. Сколько лет городу, если он был основан 3 века назад?

2. Сколько месяцев прожил ребёнок возрастом в 5 лет?

3. Сколько суток ждать 14-летнему человеку своего 16-летия? (Возможны 2 ответа: 730 или 731, если один из годов попадёт на високосный год, когда в году не 365 дней, а 366).

4. Сколько суток осталось ждать каникул, если каникулы начинаются 1 июня, а сегодня 1 марта?

5. Сколько часов осталось отдыхать маме, если ее выходные заканчиваются через двое суток?

6. Через сколько секунд прозвенит звонок на перемену, если до конца урока осталось 5 минут? 
Все эти задачи можно решать как умножением, так и сложением, т. к. осуществляется преобразование числа в сторону его увеличения, а меры времени - в сторону уменьшения. Данную особенность также можно познать посредством решения задач с опорой на эту таблицу.

Обучающимся можно предложить и обратные задачи - на выполнение действия деления, т. е. уменьшения числа, но увеличение единицы измерения путем ее преобразования. Кроме того, задачи можно усложнить, используя не натуральные числа, а дробные.

1. Сколько веков прожил человек-долгожитель, если ему 150 лет?

2. Сколько лет исполнится новорожденному малышу, когда он проживёт 36 месяцев?

3. Сколько месяцев исполнилось Катиному щенку, если он родился 135 суток назад?

4. Через сколько суток испортится молоко, если срок его хранения 72 часа?

5. Сколько часов осталось ждать до детского спектакля, если он начнется через 150 минут?

\section{3. Таблицы для усвоения арифметических действий с единицами измерения}

Для формирования понимания у обучающихся многообразия способов вычисления периметра прямоугольника и квадрата может служить таблица, представленная на рис. 76.

\section{ПЕРИМЕТР (см) (сумма длин сторон)}

a

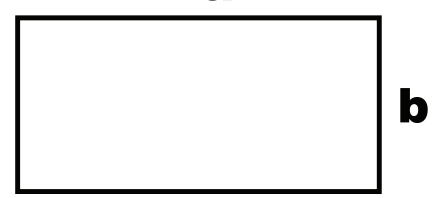

\section{a}

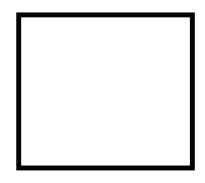

a
$P \square=a+b+a+b$

$P \square=(a+b) \cdot 2$

$\mathbf{P}_{\square}=\mathbf{a} \cdot \mathbf{2 + \mathbf { b } \cdot 2}$

$\mathbf{P} x=\mathbf{a}+\mathbf{a}+\mathbf{a}+\mathbf{a}$

$\mathbf{P}_{\square}=\mathbf{a} \cdot \mathbf{4}$

Рис. 76. Способы вычисления периметра прямоугольника и квадрата 
Учитель указывает на левую часть таблицы (правая часть при этом закрыта) и просит назвать фигуры, у которых четыре стороны, а углы прямые (прямоугольник и квадрат). Далее педагог просит обучающихся вспомнить, что такое периметр: «Периметр - это сумма длин всех сторон многоугольника». В определении периметра содержится самый простой способ вычисления периметра, если известны длина и ширина прямоугольника $(a+b+a+b)$. Затем классу предлагается выдвинуть предположения о том, как еще можно вычислить периметр прямоугольника, а затем квадрата. Ответы детей обобщаются посредством таблицы, представленной на рис. 76, т. е. открывается правая часть таблицы, в которой прописаны способы вычисления периметра и квадрата. Детям предлагается ряд задач, которые должны быть решены посредством всех указанных в таблице способов.

\section{Примеры задач}

1. Сторона прямоугольника $A B$ составляет 3 см, а $B C-7$ см. Найдите периметр прямоугольника.

2. Ширина прямоугольника равна 4 см, а длина -5 см. Найдите периметр прямоугольника.

3. Найдите периметр квадрата, сторона которого равна 6 см.

4. Сколько сантиметров будет составлять периметр квадрата с длиной его стороны в 7 см?

Данная таблица позволяет подвести знание о периметре прямоугольника и квадрата под единое основание - понимание того, что несмотря на многообразие вычисления периметра этих фигур производится поиск одного и того же числа. Обучающиеся должны выбрать оптимальный способ вычисления периметра в той или иной задаче. Такой подход способствует отрыву знания от конкретной отнесенности, его абстрагированию от частностей.

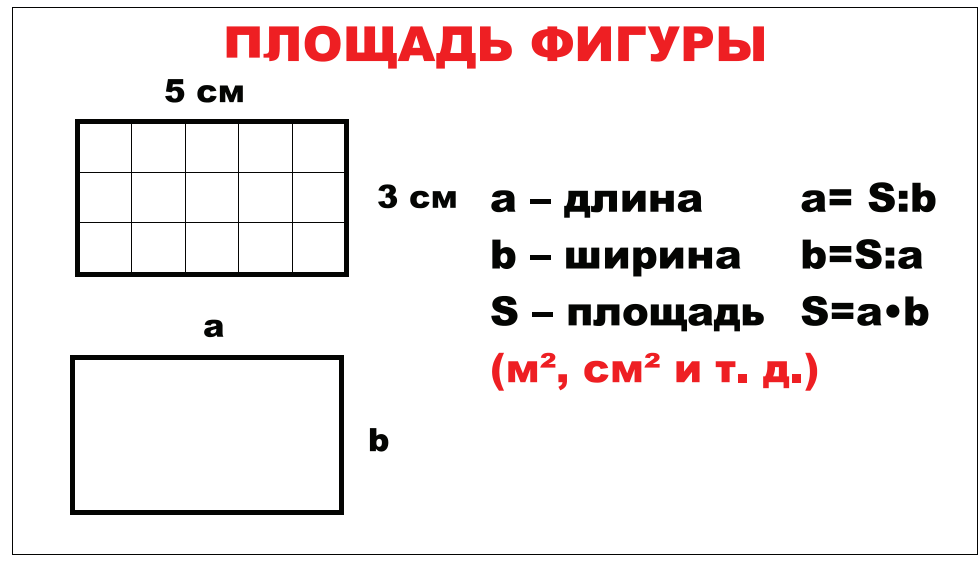

Рис. 77. Способы вычисления длины, ширины, площади фигуры 
В таблице на рис. 77 представлены правила вычисления площади фигуры, а также вычисления длины, ширины фигуры.

Учитель спрашивает обучающихся о том, что такое площадь. Ответы корректируются, обобщаются, и даётся понятие о площади: «Площадь это занимаемое предметом место на плоскости». Вместе с классом учитель приводит примеры объектов, занимающих место на плоскости: дом внутри участка, комната внутри дома, стол внутри комнаты и т. д. Далее учитель указывает на левую сторону таблицы, при этом правая ее сторона (с формулами) закрыта. На примере верхнего прямоугольника даются понятия о квадратном сантиметре, квадратном дециметре, квадратном метре, квадратном километре. Обучающиеся делают подсчет квадратных сантиметров внутри верхнего прямоугольника в таблице и приходят к следующему выводу: чтобы посчитать площадь, достаточно длину прямоугольника умножить на его ширину. В итоге дети с опорой на восприятие нижнего прямоугольника выводят формулу нахождения площади любого прямоугольника $(S=a \cdot b)$. После этого открывается левая часть таблицы, и отрабатываются способы вычисления длины при известных переменных площади и ширины и вычисления ширины при известных переменных площади и длины.

Для лучшего усвоения материала обучающимся предлагаются практические задачи на измерение и вычисление площади, длины и ширины плоскостей предметов в классе. 


\section{СПИСОК РЕКОМЕНДУЕМОЙ ЯИТЕРАТУРЫ}

1. Гальперин П. Я. Методы обучения и умственного развития ребенка. М.: Изд-во МГУ, 1985. - 45 с.

2. Кабанова-Меллер Е. Н. Формирование приёмов умственной деятельности и умственное развитие учащихся. - М.: Просвещение, 1968. - 288 с.

3. Калмыкова 3. И. Продуктивное мышление как основа обучаемости. М.: Педагогика, 1981. - 200 с.

4. Менчинская Н. А. Проблемы учения и умственного развития школьника: Избранные психологические труды. - М.: Педагогика, 1989. - 224 с.

5. Леонтьев А.Н. Проблемы развития психики. - М.: Изд-во Моск. унта, 1981. $-582 \mathrm{c}$.

6. Раев А. И. Управление умственной деятельностью младшего школьника. - Л.: ЛГПИ, 1976.- 136 с.

7. Рудницкая В. Н. Математика. 1-4 классы. Программа (+CD). ФГОС. М.: Вентана-Граф, 2015. - 128 с.

8. Русский язык: 1-4 классы: программа, планирование, контроль / С. В. Иванов, М. И. Кузнецова, А. О. Евдокимова. - М.: Вентана-Граф, 2013. $-384 \mathrm{c}$.

9. Талызина Н. Ф. Формирование познавательной деятельности младших школьников: Кн. для учителя. - М.: Просвещение, 1988. - 175 с.

10. Федеральный государственный образовательный стандарт начального общего образования (утвержден приказом Минобрнауки России от 6 октября 2009 г. № 373; в ред. приказов от 26 ноября 2010 г. № 1241, от 22 сентября 2011 г. № 2357). 


\section{ОГ ЛАВ АЕНИЕ}

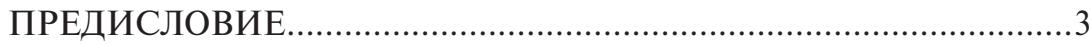

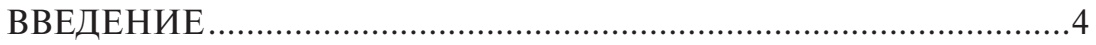

Глава 1. ТАБЛИЦЫ НА УРОКАХ РУССКОГО ЯЗЫКА ................. 7

1.1. Таблицы для изучения раздела «Фонетика» .......................7

1.2. Таблицы для изучения раздела «Части речи» ..................... 14

1.3. Таблицы для изучения раздела «Состав слова» ..................60

1.4. Таблицы на правописание орфограмм ............................6 65

1.5. Таблицы для изучения раздела «Предложение» .................85

Глава 2. ТАБЛИЦЫ НА УРОКАХ МАТЕМАТИКИ......................92

2.1. Таблицы для изучения нумерации и выполнения арифметических действий .......................92

2.2. Таблицы для изучения мер .............................................99

2.3. Таблицы для усвоения арифметических действий с единицами измерения................................................99

СПИСОК РЕКОМЕНДУЕМОЙ ЛИТЕРАТУРЫ ........................ 102 
Билалова Лариса Михайловна Иванова Оксана Михайловна Фатихова Лидия Фаварисовна

\section{РУССКИЙ ЯЗЫК И МАТЕМАТИКА В НАЧАЛЬНОЙ ШКОЛЕ В ОПОРНЫХ ТАБЛИЦАХ}

Методическое пособие

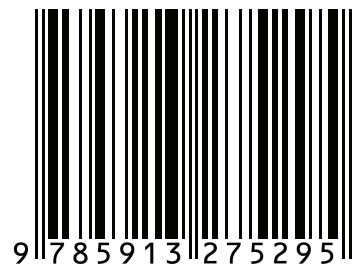

Технический редактор Кулакова Г.А.

Подписано в печать 15.05.2018

Бумага офсетная.

Гарнитура NewtonC

Формат $60 \times 84$ 1/16

Печать трафаретная. Печ. л. 6,5.

Тираж 500 экз. Заказ № 016-18.

Отпечатано в типографии ИД «Академия Естествознания», 440026, г. Пенза, ул. Лермонтова, 3 